Illinois State University

ISU ReD: Research and eData

Theses and Dissertations

9-17-2013

\title{
Financial Retrenchment: A Phenomenological Study of Two Public School Districts in One Community
}

John Andrew Asplund

Illinois State University, johnasplund@hotmail.com

Follow this and additional works at: https://ir.library.illinoisstate.edu/etd

Part of the Educational Administration and Supervision Commons

\section{Recommended Citation}

Asplund, John Andrew, "Financial Retrenchment: A Phenomenological Study of Two Public School Districts in One Community" (2013). Theses and Dissertations. 19.

https://ir.library.illinoisstate.edu/etd/19

This Dissertation is brought to you for free and open access by ISU ReD: Research and eData. It has been accepted for inclusion in Theses and Dissertations by an authorized administrator of ISU ReD: Research and eData. For more information, please contact ISUReD@ilstu.edu. 


\section{CHAPTER I}

\section{INTRODUCTION}

In today's economic circumstances, it is all too common to read about or know of school districts that are in dire financial situations. These situations often require the school board and superintendent to generate unpleasant alternatives for the district taxpayers, parents, students, and employees; such alternatives as school closings, consolidations, referenda, program cuts, and salary and/or benefit freezes. In many instances, the school is the community's identity, and people fear that if the school is forced to cut programs or close, then the community will lose its ability to remain viable.

On the other hand, many schools have found it increasingly difficult to generate the requisite amount of local funds needed to maintain current programs. In the case of Illinois, over $10 \%$ of school districts in the state were either under financial early warning or financial watch by the state (Illinois State Board of Education, 2008). This has forced many leaders to begin considering budgetary cuts and managing the decline to minimize the damage to the school district and its children.

If schools existed in a vacuum, cuts could be made without regard to what the community expects from the school. Peripheral programs would be cut in order to ensure that the core academic programs could remain. But schools do not exist in a vacuum. There would most likely be intense pressure to maintain all the school's programs, since each program is special to some group of people within the community and within the school. Still, cuts need to be made...so what is a Superintendent and School Board to do? The following is an examination of these problems as they exist today in public schools, and specifically in Illinois. 


\section{Cutting Expenditures: A Theoretical Approach}

By topic the literature is rich in data on the fiscal impact of decline, less rich in generalizable data on the programmatic impact of decline, and relatively limited (except case studies of varying generalizability) on the processes of responding to decline, and the impact of those responses. (Zerchykov, 1982).

During years of expansion, school leaders' decision-making is relatively easy. New employees are hired, extra monies are available, and a sense of optimism permeates organizational activity. Even the question of who makes these decisions, and how, are of little concern. But in times of retrenchment, the situation is reversed. Decision makers and their decision-making processes come under intense scrutiny. People are fired, resources are eliminated or reallocated to more fundamental priorities, and low morale and conflict taint the organizational environment. In decline, the question is no longer "who gets what" but "who absorbs the cuts." In Boyd's (1982) terms: "There is a fundamental shift from distributive to redistributive politics: a shrinking budget creates clear winners and losers and no slack resources remain with which to buy off the loser with side payments on secondary issues" (p. 70).

Berman and McLaughlin (1978) find that educational cutbacks during decline are not processes of a reversible nature, compared with add-on processes during expansion.

District expansion was frequently accompanied by organizational growth in which new activities became part of the ongoing school operations. Some of these activities constituted a new level of organizational functioning that were added on to the system in ratchet-like fashion. District officials and policymakers risk a possible long-term erosion of the quality of educational delivery by assuming they can simply subtractout that which was added-on during expansion (p. 13). 
The costs of reversing decisions made during expansion may be hidden as well as high. Dembowski (1979) argues that money was used in periods of expansion to control conflict, as well as to solve problems:

In the period of growth, money was fairly easily obtained and was often used by the school administrators to control the level of conflict among interest groups in the school district. Money was often used as the resource buffer between conflicting groups. As this buffer is eliminated, administrators can no longer "buy" their way out of problems, but are forced to use other alternatives to satisfy the needs of diverse pressure groups. The predictable result of the elimination of the "economic buffer" is that the level of conflict in school districts has risen. (p. 18).

With little slack and increased potential for conflict in the "redistributive politics" of decline, it becomes difficult to find alternatives when all choices appear to be bad ones. Freeman and Hannan (1975) demonstrate that school districts have been slower to act in decline than in growth. This should not be surprising, as unpleasant tasks are often put off, possibly onto another group of decision-makers at a later date. But what if a school district faces such an alarming shortfall that decisions must be made quickly? This is where the literature falls short.

To summarize the points made above, during times of economic prosperity, school districts are relatively free to make decisions regarding expenditures. Both the external and internal publics associated with the school district are relatively happy, because programs that are important to them are either maintained or expanded. During times of retrenchment, when priorities need to be defined and maintained, the decision makers in a school district are under a tremendous amount of pressure to maintain programs. This can become an untenable situation, as not all programs can be saved or at least maintained. At some point, cuts will need to be made and people are going to be unhappy. 


\section{Prior Research}

There is very little current research in the area of retrenchment or management of decline. The studies cited here are from the late 1970s and early 1980s and they, unfortunately, don't come to any certain conclusions as how to effectively deal with the problem of financial cutbacks.

Cuban (1979) performed a qualitative study of the retrenchment process in Arlington, Virginia in the late 1970's. His primary focus was the impact on the professional staff and their aspirations for promotion. In times of retrenchment, there is little opportunity for promotion, as administrative positions are among the first to be eliminated. This drives down the morale of the professional staff and may lead the best and brightest among the staff to look outside the district for professional advancement opportunities.

Freeman and Hannan (1981) used quantitative data from 823 school districts in California and 849 school districts in New York to compare organizational response in staffing patterns between declining and growing districts throughout the 1970's. Districts, in general, react more slowly in decline as compared to growth. When enrollments swell, teachers are added quickly to account for larger class sizes. When enrollments drop, layoffs do not happen as quickly.

Boyd (1979), in his qualitative study of eight suburban Chicago school districts, focuses on the policy making process during times of decline. His primary area of interest deals with the politics of school closings and how districts tend to choose schools to close. Typically, in multi-building district, school leaders will close the schools with the least amount of public support. For example, one high school district under study had 
four separate campuses, grades 9-12. When the district experienced a substantial contraction in population, the newest building was closed. This would seem curious, as the newest building was the least expensive to maintain; however, it was also the building with the smallest alumni following. After surveying the community, the board elected to close the most efficient building, as it was the most politically expedient decision.

Nowakowski (1980) conducted a qualitative study of two school districts in Illinois that were experiencing drops in enrollment. The loss of student population corresponded with a sizeable drop in revenue. He found that both districts looked to their management structure and took efficiency measures to eliminate some administrative positions.

Sargent and Handy (1974), Keough (1978) and Eisenberger (1977) looked at how school districts involve others in the decision-making process. They all see the management of decline as a "people problem" as well as a technical problem to be solved through rational processes. According to these theorists, effective decisions will only be made if proper processes for making decisions have been put in place prior to the time decisions need to be made. Even if the proper processes are put into place and followed, poor decisions can still be made, the theory goes, if the decision-makers don't rely on participatory decision-making with efforts made to include many groups of people in the decision-making process.

Berman and McLaughlin (1978) and Dembowski et al. (1979) state that any retrenchment must be attempted through the involvement of those that will be affected by the retrenchment decision(s). It is through this involvement that support can be generated for any changes that would occur as a result of the retrenchment; however, evidence on 
community involvement (most notably the works of Morgan and Wofford (1977), Nuttall (1976) and Yeager (1979)) does not show that involvement brings support in all cases. In fact, in Nuttall's work, conflict is not shown to diminish either. So, this leaves decisionmakers with no sure-fire strategy to implement when working through retrenchment. On one hand, there is research that suggests that shared decision-making is the only way to successfully work through retrenchment. On the other hand, there is research that shows no correlation between shared decision-making and increased levels of success or decreased levels of conflict. As the previous section shows, research on public sector (specifically, public school) retrenchment is neither recent nor conclusive. Is there any current research that can shed light on the issue of retrenchment? For that answer, we look to the private sector.

According to Boyne (2006),

It is important to stress at the outset that public and private management are significantly different in several respects. For example, public organizations are generally more bureaucratic, public managers have less discretion over organizational missions and personnel, and staff in public organizations are less likely to be motivated by financial incentives ( $\mathrm{p}$. 366).

This distinction is important when comparing private and public sector management, because financial retrenchment in the private sector is focusing, in general, on profitability, while public sector financial retrenchment is generally focused on breaking even. Boyne goes on to say that, when looking at private sector responses to financial turnarounds, the performance of these institutions is measured through indicators of financial success such as profitability and return on investment (Winn, as cited in Boyne, p. 373). 
These measures neglect important performance criteria in the private sector such as corporate social responsibility, welfare of staff, and impact on the environment. In the public sector, the definition and measurement of performance is even more complex (Boyne, p. 373).

Public sector entities have different stakeholders, as compared with private sector entities. In addition, these public sector stakeholders use different measurements for success, other than profitability. Often, these goals are political in nature (Rainey, 2003, as cited in Boyne, p. 373). Since the researchers cited above do not specifically target public schools, it is difficult to compare public schools specifically with private sector entities; however, we can attempt to narrow the scope even further and look at only the decision-making that takes place in private sector retrenchment.

According to Mintzberg, Ahlstrand and Lampel (1998), there is a huge amount of literature on strategy formulation in private organizations; however, there is almost no literature that speaks to the strategy process that should or should not occur (Shook, 1998).

Should the search for a turnaround strategy be rational and analytical or incremental and intuitive? Should it be centralized and secretive or decentralized and participative? Studies of turnaround in the private sector have few lessons to impart on these issues to public management researchers or practicitioners (Boyne, p. 375).

According to Hambrick (1985), there is only one important point that emerges from the literature on private firms: Action has to be quick to salvage a failing company, and it needs to be right the first time because there will probably not be a second opportunity. This would imply that any strategy for confronting the issue of financial retrenchment in the private sector must be reliant upon a compressed time schedule. This would imply that speed is desired over diversity of opinions and/or broad participation. 
In the public sector, too, agencies that are highly visible and politically salient are likely to be under pressure to rapidly produce a recovery plan. Organizations that are not in the spotlight, by contrast, may be able to adopt a more analytical and consultative procedure for formulating a turnaround strategy (Boyne, p. 375).

In terms of public schools, they are constantly in the spotlight of the community. It can be inferred from this research, then, that since schools are in the spotlight, they will more than likely be under pressure to rapidly produce a recovery plan. But once it is decided that a plan should be made, how should those decisions be reached?

According to March (1994) and Quinn (1996), decision-makers all too often rely on past experiences without truly considering all the other alternatives that could have happened. Instead, managers assume that their past successes will help guide them to a rational conclusion. These authors argue that, in most cases, decision-makers tend to believe they can make authoritative decisions, even though the potential outcomes are unknown. While it is certainly possible that sound decisions will be made, research shows that success may very well be an act of random occurrence, rather than preordained by human will.

Argyris (1992) states that decision-makers will also go out of their way to avoid causing themselves embarrassment or stress, so they purposely avoid discussing issues that may reflect poorly on themselves. If this type of decision-making occurs, a true examination of a district's budget may be all-too often ignored.

The research that is available gives no clear direction for a practitioner. Should the community be involved in the decision if there is no guarantee that their involvement will neither serve to generate desirable alternatives nor will it reduce the amount of conflict between and among interest groups within the community and school districts? 


\section{Study Problem and Purpose}

Although there is great concern about the adequacy of funding for schools, few researchers have examined how school district administrators manage the fiscal retrenchment made necessary by budget reductions. The research that does exist is dated and examines the impact of relatively small reductions in revenue streams over time and does not provide insight into how districts cope with significant budget cuts that result from a change in the mix of revenue sources on which they are dependent. Therefore, the purpose of this study is to understand how the leaders of two school districts in the same community dealt with the closure of a local power plant that had accounted for approximately $45 \%$ of the districts' revenues.

\section{Research Questions and Method}

To gain a better understanding of the problem of how two school districts within one community dealt with drastic budget cuts, the following question will guide this study.

From the perspective of board members and administrators...

How did these school districts react to the closure of a large source of revenue (the power plant)?

Interviews were used to gain a better understanding of how the problem was perceived by the school board, administration and community. The case study analysis approach was the preferred method of inquiry in this study, for a qualitative case study "is an intensive, holistic description and analysis of a single instance, phenomenon, or social unit" (Merriam, 1998, p. 27). To better understand what happened in this community, I needed to gain a deeper understanding of the community itself. As Stake (1995) states, "A case study is expected to catch the complexity of a single case" (p. xi). 
For our purposes here, the single case is the community and its two school districts responding to a financial change in reality.

Beyond interviews, I collected district and public documents that refer to the districts' financial troubles. Examples of documents collected include board minutes, newspaper articles, annual financial reports, budgets, and board presentations. These documents were used to help place the comments of the interviewees into some sort of context. It was important to review these documents, for they reflected the public stance of the school districts in regards to how they said they were dealing with the need for financial retrenchment. These statements were then compared with the statements of the interviewees, where special attention was placed on comparing what each district said they were going to do and what each district actually did to financially retrench each district.

\section{Research Validity}

"Internal validity deals with the question of how research findings match reality." (Merriam, p. 201) As previously stated, the collected documents were used, primarily, as a means of comparing what the districts claimed they were doing to address the financial retrenchment issue with what they actually ended up doing. The documents helped verify what the interviewees said happened in their community. In addition, Cresswell (2003) suggests that a case study researcher should also enter into the practice of conducting multiple session interviews so that follow-up questions can be asked (p. 196). I followed this particular type of protocol in one instance, as new, unforeseen information was gathered in an interview with the high school district superintendent. 
The second interview was needed to clarify issues and to delve further into this newfound information.

\section{Researcher Subjectivity}

I have been a district superintendent for seven years. Prior to becoming a superintendent, I served as building principal at two different high schools. My eleven years of administrative experience allowed me to relate and empathize with the administrators in their reflection of the process of retrenchment. At the same time, I sometimes found myself second-guessing these people, as I feel that I have the requisite background to carry out these tasks and I very well may have carried them out in a different manner and with a different goal in mind; therefore, my first subjective lens is that of a current school administrator.

My second lens of subjectivity will be that of neighbor. The community under study is relatively near to my home. I have read about the retrenchment process while it has gone on. I work with people who live in this particular community and I have discussed the details surrounding the plant closure with many of them; therefore, I not only carry my own biases, I carry some of theirs, as well.

\section{Conceptual Framework}

The purpose of this study is to understand from the perspectives of school board members and school administrators, what happened in a particular community, to two separate and distinct school districts, after they learned of the closure of an electric generating plant. The closure necessitated action from both schools, as property tax revenue dropped precipitously for both school districts. The units of analysis are the 
respective school districts, focusing on those who were directly responsible for carrying out the cuts (namely, the boards of education and administration).

In addition, part of my understanding of this problem is informed by theories of the symbolic nature of schools (coupled with theories of organizational politics), and resource dependency theory. The main source of organizational political theory comes from Bacharach and Lawler (1980), who postulate that any attempt to understand organizational politics must understand two issues: the formation or mobilization of interest groups into coalitions; and the nature or pattern of conflict between different coalitions (p. x). And the main source for discussions on resource dependency theory will be based on the work of Pfeffer and Salancik (2003), who develop many theories based around the central theme of the importance of the environment or the social context of organizations for understanding what decisions got made (p. xi).

\section{Research Design}

The case study approach is most appropriate for this study because, in case study research, "we emphasize placing an interpreter in the field to observe the workings of the case, one who records objectively what is happening [or, in our case, what happened] but simultaneously examines its meaning and redirects observation to refine or substantiate those meanings." (Stake, pp. 8-9) It will be important to attempt to interpret what happened, because it will be useful to learn from each district's successes as well as their mistakes throughout the process of retrenchment. In order to answer "how" and "why" things happened the way they did, an explanatory case study approach is appropriate.

According to Yin (1994), an explanatory case study approach is appropriate for answering "how" and "why" questions regarding activity within a context where the 
researcher has little, if any, control over the events. Since the focus of this study is to discern how two separate school districts in one community responded to a calamitous reduction in sustainable revenue, and how these districts evolved once these decisions were made, the case study approach seems appropriate for this research.

Case studies have been described as particularistic, descriptive and heuristic (Merriam, 1998, p. 29). This case study is particularistic because it focuses on a particular set of issues...the closure of the electric generating plant and the ensuing financial difficulties of the school districts that derived revenue from the plant. This case study is descriptive because it will provide a varied and rich description of what happened in and to a small community when the electric generating plant closed its doors. It will provide documentation of events, quotes, samples and artifacts (Wilson, as quoted in Merriam, p. 30). Finally, this case study is heuristic because it will "illuminate the reader's understanding of the phenomenon under study" (Merriam, p. 30).

The flexibility inherent in case study design precluded the use of highly structured interviews, because such a format may not have allowed the researcher to achieve an accurate picture of the participants' experiences and understandings of the districts being studied. Instead, a semi-structured interview format was followed to ensure that certain topics were explored, while allowing for differences in each interviewee and to allow the interview to explore as many of the issues as possible, given the relatively narrow scope of the situation (we will not be examining any other factors relating to the plant closure other than the loss of property tax revenue).

My experience as a school superintendent has allowed me the opportunity to make budget cuts. I know from personal experience that it is difficult, at best, to 
eliminate opportunities for students. These efforts are met with hostility and frustration from the faculty, staff, students and community. Throughout my efforts to determine what cuts should be made, I was pressured by board members, teachers and parents to avoid recommending cutting certain programs. There was no way I could please everyone. In the end, the school board and I were lucky: we were able to solve most of our financial problems through an unexpected increase in revenue. We were spared the fate of deep and lasting cuts. We never had to cut entire programs and adversely affect the lives of employees and students alike. One of the districts under study was not spared the same fate.

\section{Definition of Terms}

The terms listed below are included to give the reader a better understanding of the issues pertaining to public school funding in Illinois.

Average Daily Attendance (ADA): The average number of students who attend a school district in a day. This number is used when calculating a district's level of financial assistance in the form of state aid.

EAV (Equalized Assessed Valuation): The total taxable value of property within the boundaries of any taxing body in the state of Illinois (Education Funding Advisory Board (EFAB), 2002, p. 4).

Foundation Level: The minimum amount of money a school should spend per student in a given school year. This number is used when calculating school districts' state aid allocations. 
General State Aid: The amount of money school districts receive on a formula basis regardless of the programs being offered. Components of the formula include pupil attendance, the district's EAV and a foundation amount.

Per Pupil Expenditure: The total amount of money a school district spends divided by the number of pupils the district serves. It is often used to illustrate the relative wealth of a school district.

Property Tax Extension: The total amount of tax money distributed to a taxing body.

Property Tax Rate: The percentage at which a taxing body can tax the property within its borders.

Property Values: The taxable value of a piece of real estate.

Resource Dependency: To survive, organizations need resources. Typically, acquiring resources means the organization must interact with others who control those resources (Pfeffer and Selancik, 2003, p. 258).

\section{Significance of the Study}

As previously stated, the literature is rich in data on the fiscal impact of decline, but is generally less rich in examining the processes that have been taken when a calamitous drop in revenue occurs in a relatively short period of time. And, as previously written, if schools existed within a vacuum, cuts could be made based on academic impact and cost/benefit analysis alone. But schools do not exist in vacuums and there are societal pressures placed on school boards to protect certain programs that are seen as having greater value to the community...even if the program provides little or no academic benefit to the children in the school district. 
The study will present much of the available literature relating to this subject; however, in truth, there is little literature available. This particular area of study has been largely ignored, so the true significance of this study will be that it will be virtually the first of its kind and it will provide a foundation for future study.

The study consists of on-site fieldwork in the two participating districts to interview the aforementioned administrators and school board members. These interviews did not occur until their anonymity was guaranteed and an agreement was signed.

The administrators were asked to provide the researcher with copies of district budgets and annual financial reports for the past five years, which encompassed time before the cuts were made, during the cuts, and through the retrenchment process. In addition, the researcher asked to be provided with board minutes and agendas from the same time period.

\section{Organization of the Study}

Chapter I has provided an introduction into the financial problems that faced two separate school districts that serve one community in Illinois. Also included were the definition of key terms, conceptual framework, research questions, design of the study, assumptions and limitations of the study.

Chapter II presents a review of the literature pertinent to understanding public school finance in Illinois, and some literature dealing with school leadership and the symbolic nature of schools. Finally, a summary of research pertaining to decisionmaking and retrenchment is included. Since there is no recent research pertaining to this particular issue, an additional section on private sector retrenchment is included, as well. 
Chapter III presents the research methodology and a detailed account of the districts under study.

Chapter IV presents the data and an analysis of the data for the high school district under study.

Chapter $\mathrm{V}$ presents the data and an analysis of the data for the elementary district under study.

Chapter VI presents an interpretation of the findings in light of the literature and suggests implications for further research and policy development. 


\title{
CHAPTER II
}

\section{REVIEW OF THE RELATED LITERATURE}

\author{
Introduction
}

The literature contains a great deal of information on organizational management and behaviors regarding the distribution of monies in a school district. The literature is virtually absent when discussing drastic cuts that must be made over a very short period time. No substantial research or commentaries have been made regarding PK-12 public education since the late 1970's. We must look to research and commentaries on the private sector to review any recent thoughts on the subject of retrenchment. It is also important to consider any pertinent theories on decision-making and how decision makers go about working through problems before any large-scale decisions are made. But first, in order to truly understand the districts under study, it is important to offer a summary of the system of public school funding in Illinois.

Public School Finance in Illinois

The following section is broken into several sections. The first section offers a brief overview of the property tax system in Illinois. The following three sections illustrate how different school districts in Illinois are impacted in disparate ways. The sections are organized without regard to district size. Instead, the sections are broken down by their geographical base, be they rural, suburban or urban districts. Finally, the last section summarizes how property tax revenues and general state aid are related to one another as they pertain to a school district's revenue stream.

A Brief Overview of the Illinois Property Tax System 
The two districts under study were forced to deal with a precipitous drop in revenue as a result of the closure of a power plant in each of their districts. In order to more clearly understand each district's predicament, it is necessary to possess a basic understanding of how Illinois funds its public schools. The following is an explanation.

Four major factors determine the amount of money available for a school district. They are as follows:

- Property Values - The total property value in a school district determines how much revenue a school can generate locally (via property taxes). Some school districts have extremely high property values, sometimes including industry, shopping malls, or generally expensive homes. Some school districts have low property values. The Illinois finance formula is designed to account for the disparities in property wealth between school districts. This comes through state appropriations, which will be explained later.

- Tax Rates - Maximum tax rates are established by the state of Illinois, and these values can only be changed by local referendum. The voters of the district would have to approve raising their local taxes beyond the statutory limit. "Like property values, tax rates play a key role in determining the amount of a school board's local revenue. Also like property values, tax rates are usually beyond the school board's control" (IASB, 2002, p. 3). Property values are set by the market and the local assessor, and, as previously stated, tax rates are generally the control of the state of Illinois.

- State Appropriations - General State Aid is designed to funnel the greatest amount of money to districts with the lowest property values. The amount of 
money that a school district receives in general state aid is determined by how much money can be generated locally when considering how many students a district enrolls.

- Pupil Enrollment - "The Illinois resource equalization system - which involves two out of three school districts - assumes that school costs go up or down precisely with pupil enrollment, that it costs exactly twice as much to educate two pupils as it does to educate one. The school board's revenue budget, therefore, goes down when enrollment declines" (IASB, p. 4). Basically stated, a school district will see its state appropriations decline if its enrollment declines, and vice versa.

So how is state aid allocated to schools? In order to understand this process, another term needs to be introduced: the Foundation Level. This number, set by the state, is the minimum amount school districts will receive, per pupil. For example, let's assume the Foundation Level is set at $\$ 5000$. Also, for this assumption, a school district has an average daily attendance of 1000 students. According to the state, that school district should receive at least five million dollars (five thousand times one thousand). If a school district can generate four million dollars locally through property taxes, the state will send one million dollars in state aid to the school district.

There are three different formulas through which a school district can receive state aid funds. This is only important to note to show that the state of Illinois attempts to funnel state dollars to the most needy of school districts. A comprehensive examination of the three formulas is not necessary for the purposes of this study; however, it should be noted that the formulas are based on the ability of a district to generate funds at the local 
level. The greater amount of money a school district receives at the local level, the less money the state will transit to the school (Illinois State Board of Education, 1999).

The processes and formulas are based on a district's aggregate property wealth and the total number of students in the district. If a school district can raise substantial dollars on its own through property taxes, the district should not receive as many dollars per student as a district that does not have the property wealth to do so. The state of Illinois is very diverse, with rural, suburban and urban school districts. The impact of the state funding and property tax formulas affect each in a different way. While not all rural, suburban or urban districts are the same, we will attempt to generalize the impact of fiscal decline for these groups of schools. In addition, a section the property tax cycle in Illinois is also included, as this process impacted both districts under study.

\section{Impact on Rural Districts}

"Illinois has 249 school districts serving fewer than 500 students. The latest census figures show that in more than 200 of those districts, about 80 percent, the number of school-age children within those districts' borders will drop..." (Kelley, 2002, pp. 12). Not all of the small school districts in Illinois are rural, but the majority are. As more and more people leave the rural areas for the urban and suburban, the rural school districts feel an economic burden. Using the examples of the Foundation level associated with state aid from above, let's assume a rural school district that had 1000 students that generated five million dollars now has 800 students, due to declining enrollment. Using the same figures from above (although the Foundation Level rises almost every year), that's 200 fewer students. Take those 200 students times five thousand dollars and you will quickly see that that is a drop in revenue of one million dollars. At a time when 
farmland assessments are dropping or staying static, rural school districts are experiencing a drop in overall revenue.

\section{Impact on Suburban School Districts via the Property Tax Cycle}

Suburban school districts, while typically the wealthiest in terms of total property value, suffer from tax caps (a subject deserving of further study, but, for the purpose of this study, neither district is under the property tax cap; therefore, the issue will be purposely ignored) and another problem, rapid growth. In order to understand this particular issue, you have to understand the property tax cycle of Illinois.

This cycle takes twenty-one months (unless you are dealing with farmland assessments, and then the process is longer). If the assessment process is on schedule, counties have their prior year equalized assessment information by the spring. School districts, now knowing the prior year's assessment values, can begin to calculate how they will ask for money (through the levy process). Taxing districts prepare their levy ordinances by the last Tuesday in December. The money they are levying is for taxes collected in that year. So, for example, a school district levies in December of 2005 for money that will be collected in 2006. That money is then dispersed in 2006 (Taxpayers Federation, 1994). A fast growing district can add as many as three thousand students per year. Most of these students are moving into newly developed homes. These homes won't be part of the then current extension. So, taking the Foundation Level example, three thousand students will each cost five thousand dollars to educate. Three thousand times five thousand is fifteen million dollars. Where is a school district going to find an extra fifteen million dollars to fund teachers, buildings, supplies and materials? This cycle is problematic. 


\section{$\underline{\text { Impact on Urban School Districts }}$}

Urban school districts face many of the same problems as rural and suburban districts. Tax caps erode an urban district's ability to collect the appreciating value of property within its boundaries. Urban districts have seen both growth and decline in enrollment, depending on the district. Many of the same problems listed above apply to urban school districts, as well. An acute problem in many urban districts is poverty. "Research has consistently shown that variation in achievement is largely accounted for by poverty. Student achievement at each school level has a significant impact on later success. A child who hasn't learned to read by the end of the third grade may never be able to catch up and could have difficulty throughout his or her school career..." (Education Funding Advisory Board (EFAB), 2002, p. 2).

Poverty also impacts the dropout rate. Fifty percent of Illinois welfare recipients are high school dropouts. Like most states in the nation, Illinois data show several disturbing achievement gaps, especially for low-income students. "Nearly $70 \%$ of the variation in test scores can be attributed to income status" (EFAB, p. 3).

In general, it costs more to educate students who come from poverty because, statistically speaking, these students are at risk of academic failure. These students need more intensive support to help them succeed. "Students in poverty are estimated to need 1.2 times as much money as other students do" (EFAB, p. 4). The problem is greater in urban districts because these districts have fewer local resources per pupil. Poor people generally live in homes of lesser value, economically speaking. "In fact, districts in Illinois that have low concentrations of poor students have approximately 1.5 times more EAV (Equalized Assessed Valuation...the total value of property in a district) and 
property tax revenues than districts with high concentrations of poor students" (EFAB, p. 4).

The state of Illinois attempts to counter this reality with a different state appropriation called the Poverty Grant. In short, this poverty grant weights the ratio of low-income students in a district and attempts to deliver even more state funds to those districts. The Department of Human Services determines the number of low-income students. So, if a school district has a high ratio of low-income students, that school district receives a greater amount of money from the state separate from General State Aid. The problem with this formula is that high-mobility students are often missed in the count. If a school district has even $10 \%$ of its students moving in and out of the district, the DHS counts may not be responsive to this reality.

If an urban district has 20,000 students, and $75 \%$ of them are low-income, then the state should recognize this in the Poverty Grant; however, if $10 \%$ of this $75 \%$ are not counted, the district could lose a great deal of money. Let's say, for instance, that a district receives $\$ 355$ dollars for each low-income student; then take 20,000 times 75\%: 15,000 . Now take the $10 \%$ of 15,000 that the state has not counted for that district $(15,000$ times $10 \%): 1,500$. Now take 1,500 times $\$ 355: \$ 532,500$. That is a substantial amount of money that the urban district did not receive that it desperately needs to provide adequate support for the children from low-income families.

\section{Property Taxes and General State Aid}

To better understand the plight of the districts under study, a further examination of the property tax cycle, as it is related to disbursement of general state aid is needed. 
As described above, using similar figures, suppose a district has 1000 students and the foundation level is $\$ 5000$. The state assumes that the school district should receive at least $\$ 5$ million. If that school district can raise $\$ 4$ million through its levy process, the state will then appropriate $\$ 1$ million to the district. If a school district can generate more than the $\$ 5$ million above, then that district receives a flat amount per student, depending on the district's wealth. So, it is possible in property wealthy districts to still receive money from the state, even though you can raise enough local dollars to reach the foundation level of spending per child. In the case of the districts under study, at the time of closure, each district was considered to be among the wealthiest districts in the state, so each received a flat grant amount from the state (Illinois Local Education Agency Retrieval Network, (ILEARN) 2009). Once the plant closed, the value dropped significantly the year after the plant closed, and the value was completely eliminated by the second year. As a result, both districts went to the foundation level of state appropriations; that is, neither district could raise enough local dollars to reach the foundation level of expenditure per child. The state then began directing more dollars to each district, but the total appropriations only added up to the foundation level amount. Neither district received a combined appropriation that exceeded the state minimum. So, in sum, the property tax cycle, combined with the state foundation level for appropriations, caused a two-year lag in fully impacting the districts under study.

Much of the above shows how rural, urban, and suburban districts can be financially harmed in today's economy/reality, as each area of the state can be hit hard by precipitous drops in local resources. At some point in time, every school district will be faced with cutting expenditures, but what to cut? And how are decisions made when 
faced with such a problem? The following is an examination of the related literature on administrative reactions to budget cuts.

\section{Responding to Retrenchment}

The research and commentaries available for this study, it should be noted, are almost entirely from the late 1970s and early 1980s. (It bears noting that a correlation can be drawn between the national economic situation of the 1970s and 1980s and today. Both eras experienced sharply increasing fuel costs, which spread rising costs and increased inflationary rates to all spectra of the economy. While there is little research or commentary regarding retrenchment at the current time, I strongly believe that other researchers will more closely examine the issue of retrenchment in the near future.) While it would have been helpful to use literature that is more recent in nature, the claims that are made in the following can still be made today.

The following is broken into sections that relate to particular issues that arise in retrenchment. The first several sections offer the reader a survey of literature on issues such as leadership, planning and involvement. The final section is devoted to prior research on the subject of retrenchment. An attempt was made to review only retrenchment practices in education; however, there is so little research on the subject that, in order to use more current works, a subject on retrenchment in the public sector was added, as well. To start, though, we will look at the issue of rationality vs. politics.

\section{$\underline{\text { Rationality vs. Politics }}$}

Are schools seen as rational purpose-driven organizations in which decisionmaking responds to creative leadership and follows objective-technical processes? Or are schools best seen as "polities," - coalitions of internal and external interest groups - 
whose decision-making procedures more closely mirror a process of interest group bargaining rather than objective fact-finding? (Zerchykov, 1982, pp. 163-164) No doubt there are instances where both realities are true. This reality is seen in the work of Sargent and Handy (1974) who interviewed over 100 school districts in forty states. Their report dealt directly with how future population numbers are calculated and discussed the strategies and procedures that follow when a population is too small for existing school facilities. It is also evident in the work of Keough (From Abramowitz and Rosenfeld, Ed., 1978), who conducted a case study of a particular suburban New York school district that was dealing with a significant population decline. And it is also evident in the work of Eisenberger (1977), who took a quantitative approach by examining the enrollment trends of the fifty largest school districts in the country. All of these researchers see the management of decline as a "people problem" as well as a technical problem to be solved through rational processes.

$\underline{\text { Involvement }}$

Berman and McLaughlin (1978), who summarized the collective studies, both quantitative and qualitative on fiscal retrenchment in education in the 1970s; and Dembowski et al. (1979), who surveyed 320 school districts across the country concerning the effect of enrollment changes on staffing patterns, state that any retrenchment must be attempted through the involvement of those that will be affected by the retrenchment decision(s). It is through this involvement that support can be generated for any changes that would occur as a result of the retrenchment; however, evidence on community involvement (most notably the works of Morgan and Wofford (1977), Nuttall (1976) and Yeager (1979)) does not show that involvement brings support in all cases. In 
fact, in Nuttall's work, conflict is not shown to diminish either. So, this leaves decisionmakers with no sure-fire strategy to implement when working through retrenchment. On one hand, there is research and commentary that suggests that shared decision-making is the only way to successfully work through retrenchment. On the other hand, there is research and commentary that show no correlation between shared decision-making and increased levels of success or decreased levels of conflict.

Planning

Few would argue against rational planning in response to an apparent need for retrenchment. Keough ((1978) as quoted in Zerchykov (1982)) tells of a frightening scenario for districts that do not plan for retrenchment. It bears repeating here:

Districts caught in a financial crunch have only a few possible alternatives: reduce staff and cut program(s), consolidate facilities, raise local taxes, or operate under deficit budgets...[if] tax increases are just not possible, the alternatives are reduced to making trade-offs between program and facilities. Given these basic alternatives most administrators view facility contraction as the lesser of all evils. When districts do not plan ahead, however, they are forced into what many term "austerity conditions," across-the-board cutbacks in program and personnel...The district may launch a community information program and concentrate its efforts on closing under-utilized facilities. The emphasis, timeline, and planning focus on this alternative. Frequently, community opposition is strong enough to prevent the board from carrying out the plan to close schools. This dead end, when it happens, usually occurs late in the school year and well along in the budget process. The financial crunch is imminent, the facility plan is dead, a referendum not possible, and quick decisions must be made. Only program[s] [are] left - and here lies the real threat. Program cut decisions are made under pressure, quickly, and usually without a well-thought-out plan. (pp. 165-166)

To summarize: districts that do not plan ahead for necessary cuts may often end up cutting programs that should not be cut, because buildings that could be closed will not be closed because community members will rally against any building closures. The community pressure will force the board to go against the recommendations of 
administration and force other cuts to be made. When facility cuts are not allowed, the next area to be eliminated will almost have to involve personnel in the form of program cuts. While students can learn equally well in any district building, it could be argued, they cannot learn equally well if entire programs of study are eliminated.

Unplanned cuts are to be avoided, since the requisite amount of thoughtful planning to mitigate the impact on students would not have been accomplished. Bellon (1977) echoes the thoughts listed above through his paper that was presented to the University of Kansas that concludes that school districts will more likely succeed through sound management practices. He asserts that the essentials of sound management are ...dependent upon clarity of organizational responsibility authority, and expectations. When this clarity has been accomplished, unity of purpose can be achieved. When there is unity of purpose, it is much easier to focus on and allocate resources to the high priority goals (p. 14).

But can effective leaders transform organizations by themselves, through the virtue of their ingenuity and persuasive skills?

\section{$\underline{\text { Leadership }}$}

According to Culbertson (1977), the answer is yes. He believes and espouses the belief that organizations can be given a unity of purpose and that strong leadership and leaders can capitalize on this unity of purpose and translate it to the community-at-large and lead them towards a desired end. In addition, he goes on to say that this unity of purpose can create an opportunity for leaders within a school. The opportunity arises as a result of the adversity the organization is facing. According to the author, most people are satisfied with the status quo, but when the status quo must be altered as the result of financial necessity, it becomes possible to challenge the inefficiencies and/or problems the district has ignored. 
According to Berman and McLaughlin (1978), the answer is no. Schools are a combination of many different interest groups who co-exist peacefully as long as no group is individually threatened by change. When a district must investigate and implement cost-cutting measures, this peaceful co-existence is disrupted, since there is no unity of purpose uniting the groups.

So, who is correct? The researchers and theorists who assert that effective leaders can lead a school district through retrenchment, as long as there is an identifiable unity of purpose which serves to unite everyone? Or those who believe and attest that school districts are simply a conglomeration of small interest groups who live peacefully in the same structure as long as no one is threatened by change? While there is no clear answer to the preceding questions, what is clear is that organizations that wish to successfully navigate the process of retrenchment need to have leaders who are effective decisionmakers.

At best, making decisions when you are constantly under the watchful eye of the public is difficult. It becomes even more so when long-lasting determinations must be made in a very short period of time by people who have never been forced to make such choices. March (1994) speaks to this reality when he discusses how decisions are made in the face of an uncertain or ambiguous future outcome. In particular, he illustrates three distinct biases when human decision-makers interpret history:

1. Belief conservation. Decision makers conserve belief. That is, they tend to interpret new experiences and information in ways that make them consistent with prior beliefs. Since experience tends to be ambiguous and beliefs tend to be strong, this effect is substantial.

2. Even certainty. Decision makers overestimate the probability of events they have actually experienced and underestimate the probability of events that might have occurred but did not. Thus, they tend to learn too much from the precise event that happened and learn 
too little from the many things that almost happened. They construct theories of history that make observed historical outcomes necessary, certain, and obvious, rather than a draw from a large pool of possible outcomes.

3. Anthropocentric focus. Decision makers construct anthropocentric theories of history. That is, they attribute events to the actions and wills of human beings. They attribute history to factors of intention and competence, rather than chance or happenstance. If something happens, they imagine that it happened because someone wanted it to happen or someone made a mistake (p. 183).

So, to summarize the three biases, human decision makers tend to hold onto rigidly held beliefs, even though their collective past experiences should have caused them to question some of those beliefs. These decision makers also tend to rely only on those experiences that actually happened, rather than contemplating how reality could have been different if different variables were in play at the time. And, finally, these decision makers tend to believe that the world as it is has been created by a collection of certain activities that were strictly controlled by human beings, rather than seeing life as a random sequence of actions that may or may not have been controlled at times by men and women.

According to March, then, decision makers tend to not be very inquisitive folk who tend to see life as a linear process and who also tend to believe that they know what to do, in most cases. He goes on to say that the decision maker is further doomed because they have more than likely risen to their position due to prior successes in their professional life.

Success tends to confirm beliefs and make them less vulnerable to contradictory evidence. Success tends to make it easier to see history as lawful and determinate rather than chance like. And success tends to reinforce the notion that history is due to human agency. Thus top-level decision makers are particularly likely to exhibit these interpretive biases (pp. 183-184). 
Those interpretive biases may cause those that make decisions to blind themselves to possible alternative solutions.

Quinn (1996), while providing meaningful discourse on organizational learning and how to make meaningful, long-lasting decisions, states that

[o]rganizational and personal growth seldom follows a linear plan. This is an important principle to remember. When people recount a history of growth, they often tell it in a linear sequence, suggesting a rationality and control that never really existed (p. 83).

As you can see, Quinn agrees with March on the subject of man's ability to control the potential outcomes in life. People, in general, believe that they can realistically predict what will happen based on what has happened in the past. In reality, it would be much better for decision-makers to realize that learning must take place all along any process of life, including times when decisions must be made. Quinn refers to this process as "building the bridge as we walk on it" (p. 83).

Another theorist, Chris Argyris (1992), stated that organizations, in general, when making decisions, attempt to control embarrassment or threat. These attempts are carried out in four distinct behaviors:

1. Bypass embarrassment or threat whenever possible.

2. Act as if you are not bypassing embarrassment or threat.

3. Don't discuss 1 or 2 while these decisions are happening.

4. Don't discuss the undiscussability of the undiscussable. (p. 134)

Essentially, what Argyris asserts is that, when confronted with difficult decisions, it is of paramount importance to the organization that embarrassment or threat should be minimized or eliminated. In order to accomplish this goal, decision-makers must work around or ignore any situation that could cause potential harm or humiliation. In the case 
of school districts and retrenchment, this could emerge when budgetary items are discussed for potential cutbacks. It is quite possible that some items within a budget could be considered wasteful or unnecessary spending. Items such as administrative salaries and benefits would need to be avoided, lest the community discover what the administrators earn. Other items, such as administrative travel or expenditures in programs that may be excessive, would also need to be avoided if it could be perceived that the administrators had a hand in creating such largesse.

Argyris goes on to theorize about the process of creating a budget. He states that budgets and budgeting can be related to at least four important human relations problems:

1. Budget pressure tends to unite the employees against management, and tends to place the supervisor under tension. This tension may lead to inefficiency, aggression, and perhaps a complete breakdown on the part of the supervisor.

2. The finance staff can obtain feelings of success only by finding fault with the rank and file personnel. These feelings of failure among supervisors lead to many human relations problems.

3. The use of budgets as "needlers" by top management trends to make each supervisor see only the problem of his own department.

4. Supervisors use budgets as a way of expressing their own patterns of leadership.

When this results in people getting hurt, the budget, in itself a neutral thing, often gets blamed (p. 191).

In other words, those that oversee the budget often feel they are not doing their jobs if they don't find fault with, in education terms, the teachers or non-certified staff. The staff, in turn, doesn't trust management to deal with budgetary issues in an ethical manner.

So, when you consider the works of Quinn, March and Argyris together, the role of the decision-maker is often filled by people who have an unfounded faith in their own 
abilities. They are often people who believe they can base decisions on past actions and that those past actions were rational and controlled by people. In reality, these decisionmakers are plagued by a narrow view of the situation, whereby they ignore potential consequences of past action and behavior. This often leads to a culture that is not based on organizational learning, but rather on organizational defense mechanisms that place a high priority on minimizing embarrassment or threat from the internal or external public. The budget is, then, a tool that comes under intense scrutiny when money is scarce. The rank and file personnel don't believe that management will be looking out for them and management chooses to view the rank and file personnel as people who need to be watched very closely, lest they waste the organization's money.

Effective leaders, then, would create a culture where organizational learning and adaptation would be ongoing and embedded in its daily operation. Rather than use the budget as a tool to control others, the budget would be created collaboratively and anyone in the organization who wished to have input into the budget's creation would have an avenue to do so. Decisions would be made by considering all potential outcomes, not just the same outcomes that occurred the last time a problem of this nature was confronted.

\section{Prior Research}

As previously mentioned, there is scant research on the subject of financial retrenchment in public schools. The research that has been done, is not current. There was a great deal of research performed on the issue of declining school enrollments in the 1970's, as the baby boomer generation left K-12 education. Out of that body of research, 
some studies were performed that looked at the decision-making processes during financial retrenchment. The following is a summary of that work.

Cuban (1979) performed a qualitative study of the retrenchment process in Arlington, Virginia in the late 1970's. His primary focus was the impact on the professional staff and their aspirations for promotion. In times of retrenchment, there is little opportunity for promotion, as administrative positions are among the first to be eliminated. This drives down the morale of the professional staff and may lead the best and brightest among the staff to look outside the district for professional advancement opportunities.

Freeman and Hannan (1981) used quantitative data from 823 school districts in California and 849 school districts in New York to compare organizational response in staffing patterns between declining and growing districts throughout the 1970's. Districts, in general, react more slowly in decline as compared to growth. When enrollments swell, teachers are added quickly to account for larger class sizes. When enrollments drop, layoffs do not happen as quickly. This research mirrors that of Berman and McGlaughlin (1978) who reviewed and synthesized the findings of a four-year, twophase study conducted by the Rand Corporation to examine and evaluate a national sample of educational innovations funded by Federal programs. These authors found that educational cutbacks during decline are not processes of a reversible nature, compared with add-on processes during expansion.

District expansion was frequently accompanied by organizational growth in which new activities became part of the ongoing school operations. Some of these activities constituted a new level of organizational functioning that were added on to the system in ratchet-like fashion. District officials and policymakers risk a possible long-term erosion of the 
quality of educational delivery by assuming they can simply subtract-out that which was added-on during expansion (p. 13).

Boyd (1979), in his qualitative study of eight suburban Chicago school districts, focuses on the policy making process during times of decline. His primary area of interest deals with the politics of school closings and how districts tend to choose schools to close. Typically, in multi-building district, school leaders will close the schools with the least amount of public support. For example, one high school district under study had four separate campuses, grades 9-12. When the district experienced a substantial contraction in population, the newest building was closed. This would seem curious, as the newest building was the least expensive to maintain; however, it was also the building with the smallest alumni following. After surveying the community, the board elected to close the most efficient building, as it was the most politically expedient decision.

Nowakowski (1980) conducted a qualitative study of two school districts in Illinois that were experiencing drops in enrollment. The loss of student population corresponded with a sizeable drop in revenue. He found that both districts looked to their management structure and took efficiency measures to eliminate some administrative positions.

While it has been noted that there is scant research in regards to retrenchment in the public sector, we can look to studies on retrenchment in the private sector, as they can shed some light on more recent observations on the issue.

\section{$\underline{\text { Retrenchment in the Private Sector }}$}

According to Boyne (2006),

It is important to stress at the outset that public and private management are significantly different in several respects. For example, public organizations are generally more bureaucratic, public managers have less 
discretion over organizational missions and personnel, and staff in public organizations are less likely to be motivated by financial incentives ( $\mathrm{p}$. 366).

This distinction is important when comparing private and public sector management, because financial retrenchment in the private sector is focusing, in general, on profitability, while public sector financial retrenchment is generally focused on breaking even. Boyne goes on to say that, when looking at private sector responses to financial turnarounds, the performance of these institutions is measured through indicators of financial success such as profitability and return on investment (Winn, as cited in Boyne, p. 373).

These measures neglect important performance criteria in the private sector such as corporate social responsibility, welfare of staff, and impact on the environment. In the public sector, the definition and measurement of performance is even more complex" (Boyne, p. 373).

Public sector entities have different stakeholders, as compared with private sector entities. In addition, these public sector stakeholders use different measurements for success, other than profitability. Often, these goals are political in nature (Rainey, 2003, as cited in Boyne, p. 373). Since the researchers cited above do not specifically target public schools, it is difficult to compare public schools specifically with private sector entities; however, we can attempt to narrow the scope even further and look at only the decision-making that takes place in private sector retrenchment.

According to Mintzberg, Ahlstrand and Lampel (1998), there is a huge amount of literature on strategy formulation in private organizations; however, there is almost no literature that speaks to the strategy process that should or should not occur (Shook, 1998). 
Should the search for a turnaround strategy be rational and analytical or incremental and intuitive? Should it be centralized and secretive or decentralized and participative? Studies of turnaround in the private sector have few lessons to impart on these issues to public management researchers or practicitioners (Boyne, p. 375).

According to Hambrick (1985), there is only one important point that emerges from the literature on private firms: Action has to be quick to salvage a failing company, and it needs to be right the first time because there will probably not be a second opportunity. This would imply that any strategy for confronting the issue of financial retrenchment in the private sector must be reliant upon a compressed time schedule. This would imply that speed is desired over diversity of opinions and/or broad participation.

In the public sector, too, agencies that are highly visible and politically salient are likely to be under pressure to rapidly produce a recovery plan. Organizations that are not in the spotlight, by contrast, may be able to adopt a more analytical and consultative procedure for formulating a turnaround strategy (Boyne, p. 375).

In terms of public schools, they are constantly in the spotlight of the community. It can be inferred from this research, then, that since schools are in the spotlight, they will more than likely be under pressure to rapidly produce a recovery plan.

It appears that the most recent research on retrenchment would offer only this advice...do something and do it quickly because people are watching and they want to see action. When you combine these thoughts with the research performed in the 1970's, it is also important to subtract the workforce as quickly as you added it. It will not be popular to eliminate teachers and programs, but whatever is done, should be done quickly, lest the community think that the problem is being ignored.

It is interesting that in the study of closing a building, the board of education ultimately made a quick decision but one that would appear to be the wrong decision. 
The board chose to close the most efficient building because it had the least amount of community support, as it was the newest building.

Also, when positions are eliminated, the opportunity for advancement can be eliminated, as well. The staff members that have aspirations of being promoted to administrative positions might look to other districts due to the elimination of administrative positions in their current district.

Finally, it is wise to look at financial retrenchment as an opportunity for change, as well. When the status quo must be challenged due to financial needs, the district and its leaders have a unique opportunity to solve personnel or efficiency issues while being able to place the blame on the financial goals that need to be attained.

\section{Conceptual Framework}

The purpose of this research study will be to understand what happened in two separate school districts in the same town in northern Illinois when that town's electric power plant closed its doors. The foundation of this study is based on two separate, yet somewhat interrelated conceptual frameworks. One framework is the idea that organizations (and, in particular to this study, school districts) are externally controlled by their environment (this theory is often referred to as "resource dependency theory"). A separate conceptual framework through which we can better understand the phenomena under study is the idea that school districts have a symbolic importance in the community. In order to better understand a school district's importance in a community, you need to understand the theories associated with the symbolic nature of schools.

\section{$\underline{\text { Resource Dependency }}$}


Pfeffer and Selancik (2003) attest that the most central theme of resource dependency theory is the importance of the environment in determining how decisions are made and for determining what decisions get made (such as hiring and the compositions of boards) (p. xi).

The idea was that if you wanted to understand organizational choices and actions, one place to begin this inquiry was to focus less on internal dynamics and the values and beliefs of leaders and more on the situations in which organizations were located and the pressures and constraints that emanated from those situations. (Pfeffer and Selancik, p. xi)

Prior research that we have reviewed delves into this issue, as well. In the work of Keough (1978), the scenario brought forth looked both at the decision-makers and the pressures placed upon them by the community-at-large.

Other researchers, such as Scott (1995) believe that institutions are "cognitive, normative, and regulative structures that provide stability and meaning to social behavior" (p. 33). His belief is that organizations provide structure through which social behavior can be better understood. In part, the theory of resource dependency echoes this belief; however, those scholars that align themselves with the resource dependency theorists would argue that social behaviors are more likely to define the organization than the other way around.

"To survive, organizations require resources. Typically, acquiring resources means the organization must interact with others who control those resources." (Pfeffer and Selancik, 2003, p. 258) The school districts under study are no different. They derive much of their revenue from local property taxes. The parents in the community send their children and their money to these two school districts. Those people who do not have children in the district still send their money. In return, these people expect 
certain things from the schools. To determine what these "certain things" are, the school district must interact with the stakeholders. It is almost a certainty that different people want different things from the schools.

Organizations are coalitions of varying interests. Participants can, and frequently do, have incompatible preferences and goals. The question of whose interests are to prevail in organizational actions is crucial to determining those actions. (Pfeffer and Selancik, p. 259)

To determine who has the power in an organization, all one needs to do is look to see whose interests are ultimately served.

So, how does the organization make decisions on what is best for the stakeholders while at the same time making considerations for who has the power to undo or confirm the decisions that have been made? For a better understanding of this conundrum, we look to the research on the symbolic nature of schools.

Prior to examining how and why decisions are made, it is important to understand how most schools operate. For that answer, we look to Pfeffer and Selancik's work (in Meyer \& Scott, 1983) on loosely coupled organizations.

In these organizations, high proportions of administrative or organizational management activity are disconnected with the actual work activities of schools, but are closely connected with the political and institutional structures of the environment (p. 183).

This is important because teachers work with students; they generally don't work with the budget. Parents see that the school is operating because they send their children to school each day. Administrators and boards of education are generally left to deal with the financial realities of the district. If teachers and the community are, in general, disconnected from the budgetary side of education, they may not appreciate that a new fiscal reality will change the way the district must operate. 
As stated earlier, Freeman and Hannan (1975) demonstrated that school districts act slower in decline than in growth. So, let's take this scenario forward. Teachers and the community go to work every day, the day proceeds much as most days proceed. This can continue for some time, even in times of decline. Meanwhile, the board of education and administration are aware of the precipitous drop in revenue, yet have done nothing. Very soon, the district will be in large financial trouble, yet most of the external and internal publics have seen no change. At what point does something change? Simple math will tell you that you cannot spend more than you take in forever. So, the board and administration decide to announce that cuts will have to be made. Immediately, people in the community and school district are put on the defensive, but why? For that answer we need to examine the symbolic/political nature of schools.

\section{$\underline{\text { Symbolic Nature of Schools }}$}

According to Bolman and Deal (1997), there are five components to the political frame of organizations:

1. Organizations are coalitions of various individuals and interest groups.

2. There are enduring differences among coalition members in values, beliefs, information, interests, and perceptions of reality.

3. Most important decisions involve the allocation of scarce resources.

4. Scarce resources and enduring differences give conflict a central role in organizational dynamics and make power the most important resource.

5. Goals and decisions emerge from bargaining, negotiation, and jockeying for position among different stakeholders. (p. 163)

Since this frame deals with scarce resources and their allocations, it is an appropriate frame to consider for our purposes here. In times of scarce resources, the notion of who has power becomes important.

Pfeffer (1992) defines power as "the potential ability to influence behavior, to change the course of events, to overcome resistance, and to get people to do things they 
would not otherwise do" (p. 30). For those people who have power within an organization, they will attempt to influence the change process to protect their interests. School boards and administrators are generally aware of who has influence within the community and also within the district. Attempting to cut programs that will adversely affect those power brokers can be problematic at best. For this reason, an understanding of the symbolic nature of schools is extremely important when attempting to understand the process of managing decline and retrenchment in schools. But why are symbols so important in schools? And how does the nature of symbolism play a role in cutting expenditures?

“Symbols embody and express an organization's culture..." (Bolman \& Deal, 1997, p. 217). From a symbolic perspective, organizations are judged by their outward appearances. The community only sees the school, for the most part, during athletic performances, plays, etc. It does not see the every day workings of the school. All organizations rely on myths or sagas to varying degrees (Clark, 1975).

A shared myth fosters internal cohesion and a sense of direction while helping maintain confidence and the support of external constituencies. At the same time, myths are stubbornly persistent, potentially blocking adaptation to changing conditions (Bolman \& Deal, p. 221).

When considering myths and symbols in schools, we think of the aforementioned plays and athletic events. In times of retrenchment, these peripheral programs, outside of the core content programs, are considered for cuts. This can create a sense of fear within the community, for these ceremonies and performances are precisely what the community identifies with the school. In general, the community doesn't identify with the Math or English departments, yet these programs must remain, in some form, in order for the school to remain accredited. 
The external and internal publics in a school district collectively establish the culture of the organization. But what is culture? Schein (1992) defines it as

[A] pattern of shared basic assumptions that a group learned as it solved its problems of external adaptation and integration, that has worked well enough to be considered valid and therefore, to be taught to new members as the correct way to perceive, think, and feel in relation to those problems (p. 12).

As previously mentioned, all you have to do is ask someone inside the organization what the important rituals of the institution are, and they can probably tell you. This is especially true if you ask someone who has been in the organization for a long time. The people who make up the culture are the people who make basic assumptions about what their school "is". In times of retrenchment, these assumptions can be placed in doubt. When doubt creeps in, people become defensive. When people become defensive, the issue of who has the power comes to the forefront. Those with the most power exert their influence over the entire process of cutting expenditures.

The symbolic nature of schools and the importance of these symbols/rituals make an already difficult process of cutting expenditures even more difficult. The culture of the school district is built on repetition and shared experiences. When people begin to share experiences that are unpleasant at best, the culture will more than likely begin to change.

...Millions live each day on the assumption that a reasonable degree of purposeful, effective action will be forthcoming from the many complex organizations on which they depend. Planned action, not random behavior, supports our daily lives. Specialized, controlled, patterned action surrounds us (Thompson, 2006, p. 8).

When an organization needs to make drastic changes, planning is needed. If the proper planning does not occur, random, unpredictable actions and behaviors will occur. This is 
disruptive and can damage the organization. So, any process that will result in making cuts, especially drastic cuts, that can harm, or at least alter the school culture, must be done through careful planning.

\section{Conclusion}

Chapter II has shown that, while there is some research available when dealing with the subject of budgetary cutbacks, the literature is scarce when it comes to the issue of retrenchment necessitated by a precipitous drop in sustainable revenue. This issue becomes even murkier when you factor in the fact that schools are symbols for the communities that they serve. The symbolic nature of schools is often built on the shared experiences of those who have been served by the school. When cutbacks need to be made, some of the programs on which those shared experiences were built could possibly be gone.

As previously stated, in times like these, school boards and administrators need to plan for the long-term impact of these cuts; however, in the case of the two districts under study, little time was given to make the necessary plans.

The methodology and research design of this dissertation provide a means to study what happened to two districts that undertook the tremendous tasks of retrenchment. Perhaps we can learn from their successes and failures for future knowledge and this knowledge can serve as somewhat of a roadmap for the next school district that shares this same calamitous situation. 


\section{CHAPTER III}

\section{METHODOLOGY}

This study was designed to investigate the processes used in determining what budgetary cuts were to be made in two school districts (one elementary and one high school) that served the same community. These cuts were made necessary by the closing of an electric generating facility that was part of both school districts' tax rolls.

This particular study is a qualitative case study. This type of study is appropriate, for, as Merriam (1998) states, "[a case study can be seen as] a thing, a single entity, a unit around which there are boundaries. I can 'fence in' what I am going to study” (p. 27). In our case, the "fence" is the district boundary line. The numbers of "players" within this fence are finite or bounded. In addition, a case study is appropriate because we are attempting to gain an understanding of what occurred within this bounded system. "A distinction between what knowledge to shoot for fundamentally separates quantitative and qualitative inquiry...Quantitative researchers have pressed for explanation and control; qualitative researchers have pressed for understanding the complex interrelationships among all that exists." (Stake, p. 37)

Case studies have been described as particularistic, descriptive and heuristic (Merriam, p. 29). This case study is particularistic because it focuses on two particular school districts and how these districts responded to the closure of the electric generating plant that was located within each district's border. This case study is descriptive because it provides a varied and rich description of what happened in and to a small community when the electric generating plant closed its doors. It provides documentation of events, quotes, samples and artifacts (Wilson, as quoted in Merriam, p. 
30). Finally, this case study is heuristic because it "illuminate[s] the reader's understanding of the phenomenon under study" (Merriam, p. 30).

The flexibility inherent in case study design precluded the use of highly structured interviews, because such a format may not have allowed the researcher to achieve an accurate picture of the participants' experiences and understandings of the districts being studied. Instead, a semi-structured interview format was followed to ensure that certain topics were explored, while allowing for differences in each interviewee and to allow the interview to explore as much of each district's particular situation as possible, given the relatively narrow scope of the study (there was not an examination of any other factors relating to the plant closure other than the loss of property tax revenue).

\section{Study Site Selection}

The districts under study were chosen for two reasons: (1) They were both affected by the closure of the power plant, and (2) They exemplify the peculiar nature of Illinois public schools. Even though both districts exist in the same relatively small town and serve the same families throughout their schooling, they remain separate entities. In the majority of states, individual school districts are responsible for all educational levels Pre-Kindergarten through $12^{\text {th }}$ grade (these types of districts are know as "unit districts"). In Illinois there are regional proliferations of "dual districts": one district is responsible for Pre-Kindergarten through $8^{\text {th }}$ grade (elementary districts) and a separate district is responsible for $9^{\text {th }}$ grade through $12^{\text {th }}$ grade (high school districts). This particular community offers parallel experiences of two school districts that serve the same community, yet they are separate and distinct entities that are responsible for different levels of public education. 
The two districts are parallel in that the power plant was responsible for over $45 \%$ of the overall revenue collected by each district. The two districts are also parallel because a family that has a child in the $5^{\text {th }}$ grade and the $9^{\text {th }}$ grade would have two children in two different school districts. That family pays property taxes to two different school districts that are overseen by two different school boards and superintendents. These separate school boards and superintendents reacted in a similar, but not identical, fashion.

The two districts under study serve a community of approximately 20,000 people. For years, these two districts, one elementary and one high school, operated under deficit budgets (expenditures outpaced revenues), using working cash bonds to augment the revenues in the education fund to operate their regular programs. The community that they served has been growing slowly for many years, so the two districts added and expanded programs to account for the growth in student population. Much of the money that supported this growth came from an electric generating plant a few miles to the east of the community.

In 2004, the community learned that the plant was to be closed. At the same time, the elementary school district had recently opened a new K-5 building, and the Superintendent was expecting to retire within the next two years. The high school district was about to face its own problems, as well. The high school building was completed in 1950, when the enrollment of the high school was much smaller. Fifty years later, the district had experienced a great deal of growth and had reached the point where the current facility was small, outdated, and expensive to maintain. 
To the community, the high school appeared to be doing a more effective job of living within its means, but the high school was going to have difficulty maintaining that appearance if it attempted to go to referendum to ask for money to build a new building. So, one district had already drawn the ire of many residents by building a very large elementary attendance center, and another district was reaching a point where the current building was not going to be sufficient in the coming years (assuming there was continued population growth). Couple these situations with the plant closing, whereby district residents would have to bear a greater percentage of the property tax burden, and you have the potential for creating a hostile group of taxpayers in one community.

\section{Participant Selection}

The participants for this research study were selected via the purposeful sampling method. This method assumes that "...the investigator wants to discover, understand, and gain insight and therefore must select a sample from which the most can be learned" (Merriam, p. 61). Purposive sampling is contrasted with random sampling, when interviewees are chosen at random. In purposive sampling, interviewees are hand selected to provide the interviewer the best, most detailed description of the phenomenon under study. For our purposes here, the people most able to provide these rich descriptions would be the decision-makers at that time: superintendents and members of the boards of education.

Initially, the superintendents that led each district at the time of the closure were interviewed. These individuals then provided names of others that were involved in the decision-making process at that time. In total, four high school board members were interviewed along with the superintendent. In regard to the elementary district, three 
board members and the district's business manager were interviewed along with the superintendent. Each interviewee was asked if they could provide any other names, and only three other names were given other than the names of people that were already interviewed. One high school board member declined to be interviewed and the other two board members named have died.

\section{Participants}

Cal

Cal was a high school board member. A native of Wisconsin, Cal has relocated from time to time as he has been promoted. He served one term on the high school board and decided to step down after his youngest child graduated from high school.

\section{Carrie}

Carrie moved to the community in the mid 1980's. She was asked to run for the elementary board after she became involved on an academic committee at the middle school. Carrie served one term on the elementary board.

Gayla

Gayla moved to the area in the 1980 's, as her husband wished to move closer to his family. She ran unsuccessfully for the high school board on one occasion before winning the subsequent election. Gayla is currently the high school board president. Karen

Karen only moved to the community five years ago. She spent most of her life in a neighboring community, but she decided to relocate when she was hired as the elementary district business manager.

\section{Laura}


Laura is a life-long resident of the community. She served two terms on the high school board, and was board president for her entire second term. Laura decided to leave the board at the end of her second term because her youngest child had graduated from high school.

Scott

Scott moved to the community over twenty-five years ago, when he became the director of the county's special education cooperative. He later was hired as the elementary district superintendent and remained in that position for eighteen years.

Susan

Susan was raised and educated in Minnesota, taught high school in Lake County, Illinois, and relocated to the community over twenty years ago. Susan was appointed to the elementary board and was later elected to two more terms. Susan served as the elementary board president for four years.

Ted

Ted moved to the community because his wife was born and raised there. His wife is also a teacher at the elementary school. He became involved with the school when the referendum committee for the new building was being organized. Ted served one term on the elementary board of education.

\section{Wanda}

Wanda was born and raised in the community. She was encouraged to run for the high school board because she works in a bank and has a finance background. She has served two terms on the board and she has decided to step down at the end of her current term. 
Wilbur

Wilbur was born and raised in the community, but he spent the majority of his educational career outside of the community. He was hired in the mid 1990's as the high school district superintendent. He retired from that position in 2006.

\section{Data Collection}

Following Creswell's (2003) model, multiple forms of data collection were used in order to complete a holistic view of the research problem (p. 185). In this particular study, two types of data were collected: Interviews and documents. As previously mentioned, the purposive study aimed to include interviews of board members, superintendents, and other school staff who had an active role in the decision-making processes of budget reductions in each district. The public documents collected focused on those documents that either communicate what cuts would be made, or what cuts were made. Such documents include newspaper articles, board minutes, board presentations, annual financial reports and district budgets.

\section{$\underline{\text { Interviews }}$}

The interviews were all face-to-face. The purpose of these interviews was to gain a better understanding of what happened in these two school districts after it was learned that the power plant was to close.

The interview protocols include the following:

[A] heading, instructions to the interviewer (opening statements), the key research questions, probes to follow key questions, transition messages for the interviewer, space for recording the interviewer's comments, and space in which the researcher records reflective notes. (Creswell, p. 190)

The goal of each interview was to gain a better understanding of what happened in each school district in regards to budget cuts that were necessitated by the closure of the power 
plant. It is important to mention that each interview contained different questions, because each person had a slightly different point-of-view of the phenomenon in question. While each interview began in the same fashion, and certain questions were asked of each interviewee, follow-up questions changed from interview to interview as the interviewer responded to each person as they answered the questions asked.

A list of questions used is given below:

1. Tell me about your history with the school district and how you became involved as a(n) administrator/board member.

2. Tell me about how you found out about the closing of Charlottesville Station.

3. Tell me how the district responded to the plant closure.

4. Please describe, as best you can, the steps that were taken to determine what budgetary items would be cut.

5. Knowing what you know now, what do you think the district could have done differently in response to the plant closure?

6. Was there any pressure from the community to save certain programs?

7. If I had attended board meetings shortly after the plant closure, what experiences would I see you having?

8. Looking back, what actions did the board of education take to respond to the pressure that was brought by the community?

After each interview, the researcher "prepare[d] a written facsimile, with key ideas and episodes captured" (Stake, p. 66). It wasn't so important to write down, word for word, what each interviewee said; rather, it was important to write down the meaning imparted by each person. Each person derived some sort of meaning from his or her experiences during that period in time. And it was up to the interviewer to glean that meaning and compare it to every other person's point-of-view. It should be noted that all 
interviews were recorded digitally. These recordings were loaded onto a computer and converted into digital transcripts. These transcripts were then analyzed to determine any emerging themes.

It came to pass that one follow-up interview was necessary due to a theme that developed. The follow up interview was conducted to gain further understanding on a certain issue as well as to confirm the themes identified through interviews.

\section{$\underline{\text { Public Documents }}$}

While interviews provided the researcher with the meanings ascribed by the interviewees, public documents provided a context through which to better understand the comments that the interviewees gave. According to Creswell (2003), the advantages to compiling public documents are:

- They enable the researcher to obtain the language and words of participants

- They can be obtained at a time that is convenient for the researcher - an unobtrusive form of information

- They represent data that are thoughtful, in that participants have given attention to compiling

- They serve as written evidence, and they save the researcher the time and expense of transcribing (p. 187).

As previously stated, these public documents included board reports, board minutes, newspaper articles, annual financial reports and district budgets. These documents allowed the researcher to gain a better understanding of the districts under study. In addition, these documents provided a context through which comments made by interviewees could be understood. 


\section{Data Analysis}

The preparation process for data analysis followed the initial steps recommended by Creswell (2003). Creswell instructs that the initial steps of data analysis involve reading through all the collected data and sorting it into different types. The two different types of data to be collected in this study are interviews and public documents.

\section{$\underline{\text { Analysis of Interviews }}$}

The first step in analysis was to read all of the transcripts and notes taken from the individual interviews. As previously stated, it was important to make notes almost immediately following each interview. This was important because each interviewee relayed what they personally remembered from that particular period of time. If I had waited until all interviews were conducted and then attempted to relay each person's meaning, all of the non-verbal cues and emotions of each person would have been lost or at least minimized by then.

Kvale's (1996) methods of coding, and developing categories and themes was used to condense each transcript into a meaningful analysis of what happened in and to these two school districts after learning of the power plant closure. The transcripts were reread and the audio recording was listened to at the same time that the transcripts were read. During this time, I looked for certain themes or commonalities to emerge. These themes were highlighted for analysis. Next the highlighted notes were condensed for further analysis and comparison with notes from the other interview sessions. When all notes were compared and analyzed, new themes emerged and they were interpreted, as well.

\section{$\underline{\text { Analysis of Public Documents }}$}


As previously stated, the purpose of collecting public documents was to have a context through which to better comprehend the meanings conveyed by the interviewees. To begin the analysis, it was important to read every word contained in the documents (at least the portions of the documents that directly or indirectly relate to the phenomenon under study). As each item was reread, pertinent details were highlighted for further study. The next step was to take all of the highlighted information and analyze it in its totality and to categorize the data to more easily discover any themes that emerge.

\section{$\underline{\text { Analysis Interpretation }}$}

"Two strategic ways that researchers reach new meanings about cases are through direct interpretation of the individual instance and through aggregation of instances until something can be said about them as a class." (Stake, p. 74) This study did not deviate from this philosophy. It was important to interpret both the individual interviews and the aggregate data gleaned from all interviews and collection of public documents. Through these analyses, patterns emerged and the end result was a comprehensive view of the districts under study and how they responded to the closure of the power plant.

\section{The Districts Under Study}

Tigertown is a community of approximately 20,000 (City Data, 2008, p.1). It is a community that has experienced some modest growth over the past decade (approximately 2500 new residents since 2000) (City Data, p.1). Its median resident age is 37.4 , as opposed to the state average of 34.7 , so it is a slightly older community than the state average (City Data, p.3). Its average household size is roughly the same as the state average, as is its average income (City Data, p.5). It has a smaller percentage of its population living in poverty than the state average, but it is, in many ways, a typical 
community in Illinois. Over the past decade, according to the county assessor, home values in Tigertown have risen over $\$ 80,000$, much of which can be attributed to the new home construction in town.

While Tigertown is similar to many communities in Illinois, it is somewhat unique in its number of school districts. There are three elementary districts within the city limits that all feed into the same high school district. The high school district has a student population of approximately 900 students $9-12$. The largest elementary district, District 208, has an enrollment of approximately 1100 students PK-8. The next largest district, Oneida, has a student population of approximately 600 students PK-8, while the smallest district, Ontario, has a student population of less than 100 students PK-8 (Illinois Local Education Agency Retrieval Network (ILEARN), 2009). Ontario students largely come from the affluent area of town, while the Oneida students come from the newer subdivisions to the north of town. This area is also where most new businesses are located, as well. District 208 is comprised of mostly residential areas, with a few businesses inside its borders. The high school district's borders mirror the combined borders of all of these districts.

So, a resident of Tigertown could either be a taxpayer to Ontario, Oneida, or District 208. All residents of Tigertown are taxpayers to the High School District, District 39. In many areas of the state, entire communities are part of these type of "dual districts", whereas, in many other areas of Illinois, communities are members of only one school district, a PK-12 Unit District. Each of these school districts has its own sevenmember school board, with separate school board policies, curricula, and property tax rates. The two districts that are the subject of this study are Tigertown Community High 
School District 39 and District 208, as they are the districts that benefited from the property tax dollars that were generated by the Charlottesville Electric Generating Station.

According to the county assessor, Charlottesville Station was an oil and gas burning electrical generation station whose construction was completed in 1978. At the time Charlottesville Station was placed on the property tax rolls, its taxable value was \$165 million. Due to this extreme spike in EAV for District 39 and District 208, both districts experienced a large spike in revenue. The high school district took quick action to build some amenities for its residents, such as a large aquatic and recreation center for the high school.

In the year 2000, Next Gen Power, an electric generating and distributing company, sold Charlottesville Station, along with several other power plants, to Southtown Power, an electric generating company out of California. Due to the sale of Charlottesville, the value of the plant rose far above the once-high value of $\$ 165$ million to $\$ 260$ million. This resulted in another spike in revenue for both districts... approximately one million dollars for each district. The sale of the plant, at such an elevated value, also seemed to indicate to the residents of Tigertown that Southtown Power had plans to keep the plant open in perpetuity. What many residents of Tigertown did not know, however, was that the plant was not profitable for Southtown Power. As a result, rumors began to swirl that Charlottesville may close.

The primary reason that Charlottesville was no longer profitable was the fact that Southtown's power purchase agreement with Next Gen had expired. When the plant changed hands from Next Gen to Southtown, part of the purchase agreement was based 
on a contract between the two power companies. For a period of three years, Next Gen agreed to buy the power that Charlottesville produced. At the conclusion of the agreement, Next Gen was under no obligation to continue to purchase its power from Charlottesville Station. Since the plant used the oil burning method of producing power, and that method was costly, Next Gen could buy its power from anywhere, so it looked for the cheapest price and Southtown/Charlottesville could not compete with other plants that could produce power more cheaply. As a result, Southtown Power announced in 2004 that it would close the Charlottesville Station in the spring of 2005.

The closing of Charlottesville Station was complete by the spring of 2005. At the time of Charlottesville' closing, District 39's EAV was approximately $\$ 500$ million, while District 208's was approximately $\$ 390$ million. These sizeable EAVs resulted in healthy tax extensions of approximately $\$ 9$ million for the high school and approximately $\$ 11.5$ million for the elementary (ILEARN, 2009, p. 1). Both districts received almost $90 \%$ of their total revenue from local sources, primarily from local property taxes (ILEARN, p. 1). By the end of the two-year period when the station was taken off the tax rolls, both districts had experienced an extremely large drop in EAV. The High School District went from an EAV of $\$ 500$ million that generated $\$ 9$ million, to an EAV of approximately \$325 million that generated \$7 million (ILEARN, p. 1). District 208 went from an EAV of $\$ 390$ million that generated $\$ 11.5$ million, to an EAV of $\$ 195$ million that generated \$9.5 million (ILEARN, p. 1). The closing of Charlottesville Station, under normal circumstances, would have created large problems for each district, but there were building issues that made the problem almost cataclysmic for the elementary district. 
In 2000, right about the time Charlottesville was sold to Southtown Power,

District 208 passed a referendum to close three of its schools and build an entirely new school, Centerville Elementary. Scott King, District 208's Superintendent, defended the decision:

We had three buildings. One was 100 years old, one was 75-80 years old and a third was about 30 years old. We had to do a life safety study and we found that we would have to spend in excess of $\$ 10$ million on the three buildings. We formed a citizens committee and we had all kinds of people helping and they studied everything: re-modeling, adding on, doing everything, and they finally came to the conclusion that the best option was to sell the three buildings and build one and combine all of them into one and this was in 1997 or 1998 and the building was completed in 2000. We went to the voters and the voters passed a referendum $65 \% \ldots$ Centerville alone was right at $\$ 20$ million because we combined Centerville and an addition onto Laird Middle School at the same time, so the total cost was around $\$ 23$ or $\$ 24$ million and the total cost to the district was in the vicinity of $\$ 18$ million financed over 20 years.

The High School District decided to take on a less costly, but expansive building project of its own: a $\$ 9$ million renovation to the existing building. But with the elevated EAV of Charlottesville Station, it seemed like a good time to take this on, as more money was flooding in and the district saw this new revenue stream, even with the building, as a chance to stop borrowing money. The district had gotten into the practice of using working cash bonds to partially fund the district's programs. When the additional money started coming in as a result of the spike in EAV from the sale of Charlottesville in 2000, the high school district elected to use some of the extra money to halt this practice.

When the word came that Charlottesville was going to close, it didn't take long to surmise that District 208, in particular, had a huge problem. The county assessor realized right away what the impact to the taxpayers would be. "If you were in District 208, after the closing, you saw your taxes go up 45\%, primarily due to the closing of Charlottesville 
and the bond payments that needed to be made for Centerville". The school board tried to move quickly to respond to this spike by refinancing the building bonds. Typically, when school districts refinance, it is to get a lower interest rate. In this case, though, district officials were seeking to lengthen the term of the bonds. Since the term was lengthening, the interest rate was forced to go up, not down. This angered the community's taxpayers.

The high school had problems, as well, but their most troublesome issue (in terms of time spent to deal with the issue) was not directly related to finances. The high school football coach was retiring, but he still wanted to remain Athletic Director and Head Football Coach. It should be noted that Tigertown is widely known for its powerhouse football program, and it was a very large source of pride for the community. The administration and school board were not in favor of allowing the coach to keep his athletic director position, as they had grown tired of his domineering leadership style. They wished to change the culture of the district to encourage more collegiality and they felt that as long as the coach was still running the athletic programs through his athletic director position, their aims would be thwarted. In addition, they were interested in absorbing the retirement in an effort to cut costs. Many people in the community thought the coach should be able to do whatever he wished, and those people were putting pressure on the board and administration to change their minds.

The teacher's union was also becoming more hostile toward the board and administration and much of this unrest was also related to the underlying issues with the coach. This issue was ultimately discussed in a special meeting of the board of education. So many people were in attendance that the meeting was moved to the high 
school gymnasium. And, apart from the issue with the coach, the high school board and administration had to go through the process of financial retrenchment. They knew that some expenditures would have to be reduced in order to keep the district financially viable.

So, both districts were facing issues where the community was upset and action needed to be taken to respond to each district's newfound financial problems. The following is an analysis of the time period right after Charlottesville Station closed, and how District 39 and District 208 responded to their financial plight.

\section{Summary}

The study consisted of on-site fieldwork in the two participating districts to interview the aforementioned administrators, school board members, and other employees of the school district. These interviews did not occur until their anonymity was guaranteed and an agreement had been signed.

The administrators were asked to provide the researcher with copies of district annual financial reports for the past five years, which encompassed time before the cuts were made, during the cuts, and through the retrenchment process. Other documents were collected as well (school board minutes, newspaper articles, board presentations). 


\section{CHAPTER IV}

\section{FINDINGS AT TIGERTOWN HIGH SCHOOL DISTRICT 39}

\section{A CASE ANALYSIS}

Introduction

This chapter will present the results from the case study analysis of Tigertown High School District 39. A detailed description of the study site will be followed by the answers to the research questions as they pertain to the school district. From these discussions, emerging themes will be identified.

Case Analysis I

\section{Tigertown High School District 39, Tigertown, Illinois}

\section{An Introduction to the District}

As mentioned in Chapter III, Tigertown is a community of approximately 20,000.

It is a community that has experienced some modest growth over the past decade. Tigertown has a vibrant downtown full of shops and stores. The locals populate many restaurants and taverns...especially before and after a Friday night football game. The pride of the school and its community is the powerhouse football program. The Tigertown Badgers have won two state championships and have advanced in the state playoffs almost every year.

The high school is also blessed to have a large recreation center and swimming pool on campus. These luxuries were built when Charlottesville Station came on the tax rolls in the 1970's. For over twenty years, Next Gen Power Company owned Charlottesville Station. In 2000, Next Gen sold Charlottesville Station to Southtown Power. The sale of the plant brought an increase in revenue to the district. 
The district's superintendent, Wilbur Johnson, realized that the additional money that flowed to the district as a result of the sale (via an increase in property tax revenue) would allow the district to halt its practice of using working cash bonds to help fund the regular programs that the district offered. This money could also be used, in part, to accelerate the district's plans to renovate the aging building.

Mr. Johnson was respected by the board of education for his financial acumen. He was also revered by the board for his efforts to challenge the previously unchecked authority of the football coach and athletic director, Coach K. Not everyone in town felt the same as the board, for Coach K. had experienced great success coaching the Badgers. The coach had developed a leadership style that was both domineering and intimidating. He often got his way through force of will and coercion, rather than cultivating a climate and culture of collegiality.

Some in town are concerned that football is given so much and that the coach has too much power. According to the superintendent, at one time, if you were a close associate of the football coach, Coach K., you got what you wanted. One of Coach K's best friends on staff at Tigertown High School was the band director. Several years prior to the sale of Charlottesville in 2000, a second full-time band director was hired, greatly reducing the amount of work for Coach K's friend. At about the same time, the school district decided that the French enrollments were low, so the teacher was let go and the program was eliminated. Considering the fact that the French teacher was let go at approximately the same time the band teacher was added, it gives the perception that the board listened to the coach. Some in town expressed concern over the loss of an entire language program, but the decision remained. Typically, programs are only eliminated 
when cost-cutting measures are being implemented. This decision seems curious when one program was increased for the convenience of the coach's friend, while another was eliminated entirely, thereby eliminating opportunities for students at a time when the district had enough money to double its staff in band.

\section{Coach $K$.}

Coach K. had enjoyed great success in the school and community. A graduate of Tigertown himself, he had worked in the district for over two decades and had been the athletic director for almost all of that time. Coach K. was somewhat of a lightning rod in the community, as he had a large group of supporters, but he also had his detractors. This could have come from his domineering leadership style. Many in the community and also within the school district felt that Coach K. had created a culture whereby the athletic department was able to bully and intimidate others in order to get whatever they wanted.

Superintendent Johnson described Coach K. this way:

He was more of a domineering type leader, rather than a collaborative style. So, what the board was trying to get at in their hiring practices [toward the end of Coach K's tenure] was to get people to get along with one another. But because of the length of time he had been there, he had developed his own style of leadership, and that came as a result of boards that he manipulated during that period of time. After he won his first state championship [in the 1980's], typical with a lot of coaches, he could do just about anything he wanted. His big M.O. was to go out and recruit board members, and, over time, he was able to stack the board in his favor, so he could basically do whatever he wanted to.

Coach K. was a very effective politician. He understood that as long as he had at least four (but preferably more than four) board members that were supportive of him, he could continue his domineering ways.

As years went by, Coach K. continued to enjoy the support of some board members; however, he no longer had a majority under his control. As a result, in the mid 
1990's when the superintendent's position became vacant as the result of the previous superintendent's retirement, another hometown man, Wilbur Johnson, entered the picture as the new superintendent.

\section{Superintendent Johnson}

Mr. Johnson, also a graduate of Tigertown High School, believes that he may very well have been hired to counter some of the power base that existed for Coach $\mathrm{K}$.

This opportunity [in reference to his employment at Tigertown] presented itself as a result of my hometown relationship and also as a result of how I think the perception of tension that existed between basically the athletic component of the school and the administrative side, the board side.

When he arrived at Tigertown, he detected that there were already some problems that existed between some teachers and the administration and board.

We had a union that was growing stronger in its attempt to discredit individuals in the administration and specific members of the board. And you had the whole cultural issue of the athletic department being bullies and expressing themselves as bullies...not only internally, but externally, as well.

When Mr. Johnson came to Tigertown, the animosity did not diminish. Instead, the tensions increased. As previously mentioned, Coach K. had been able to encourage his supporters to run for vacant Board of Education vacancies. For most of his tenure in Tigertown, the board was highly supportive of the coach. The administration during that time understood that in order to remain employed in the district, Coach K. should be given a sufficient amount of deference and respect. When Mr. Johnson was hired, the board was less friendly to Coach $\mathrm{K}$. and they were a board that wished to see the culture change. Consider the words of Board President Laura.

I think a little bit of it [the problems with the culture and with Coach K.] was they had had an administration that was kind of a roll over kind of administration. Then Mr. Johnson came in, and his administration was 
certainly more...Mr. Johnson is very black and white. And that's really one of the things that I like about him. But he wasn't going to play that little game with them.

\section{A Change in Culture}

Coach K., through his teams' success on the football field, had come to acquire a great deal of power within the community. Even though the makeup of the board had turned to one that was more inclined to change the district's culture, there were still a great many in the community that wished to see things stay largely the same. Tigertown was, and still is known as a community that places great value on its athletic programs. And the most influential and popular athletic program was and is football. Judging by the words of those who worked with Coach K., he chose to use much of his accumulated power to bully and intimidate those around him. The previous administration apparently felt it would just be easier to let him do what he wished. Mr. Johnson, though, did not play by those rules. His expectation was that he and the board ran the district. In fact, one of the reasons Laura ran for the board was because she could see that he would need support from the board in order to be successful. Mr. Johnson also believed that any success that he achieved while at Tigertown was due to, in part, the support that he did receive from the board of education.

That board was supportive of my recommendations and they were supportive of the big picture. They managed to have a grasp of finances and issues related to the plant. They'd been involved in the meetings with Southtown Power. They'd been involved with meetings with other school boards so they were aware of what was going on as they were also the targets of harassment from the community based upon our athletic department and they became entrenched in doing the right thing for kids overall. So they were very supportive of recommendations that I brought forward. 
At almost the same time that Southtown was purchasing Charlottesville, Coach K. approached the board concerning his retirement. He wished to sign a contract that would give him hefty raises his final three years with the district: $13 \%, 15 \%$ and $17 \%$ raises, to be exact. As a condition of his raises, he signed an irrevocable letter of resignation as teacher and athletic director. Even though he planned on retiring, he made it clear that he wished to remain the athletic director and head football coach. The board and superintendent, though, made it clear that they had no intentions of allowing him to keep these positions. Instead, they told Coach K. that he could remain as football coach, but his other positions would be given to someone else. When Coach K. signed his contract with the board, he said, at the time of signing, that he would concede to those terms. Later on, he had a change of heart. That issue will be explored in the coming pages, but, for now, other issues need to be addressed.

\section{Repairing the Building and the Budget}

Tigertown High School District 39 contains only one attendance center, Tigertown Community High School. The high school building, itself, was completed in 1950. It sits on a quiet street, on the southwest side of town. Many homes that were built in the $19^{\text {th }}$ century share the neighborhood with this three-story structure. Over time, as the needs of the students have changed, and as mandated programs have been added, the building has required renovation. One such renovation was planned for the building right about the time that the Charlottesville Electric Generating Station was being sold to Southtown Power. As previously stated, Charlottesville Station is an electric generating facility built in 1978. The energy that Charlottesville Station produced was sold to different distributors, for the purpose of redistributing that power to electrical consumers. 
Prior to the sale to Southtown Power in 2000, Next Gen Electric, an electric generating and distributing company, owned Charlottesville Station. Next Gen owns a fleet of power stations, and, in 2000, Next Gen sold a portion of its fleet to Southtown Power. Charlottesville Station was one of the plants that was sold in that agreement. As a result of the sale, the EAV of Charlottesville Station was increased by over $\$ 100$ million. This spike in EAV resulted in an additional \$1 million of annual revenue for District 39.

The sale of the plant was a sign of good fortune for the high school. With almost one million dollars in additional revenue coming in, it was time to renovate the building and to eliminate the practice of using working cash bonds to operate the district's regular programs. Prior to the sale of Charlottesville Station, the district had gotten into a habit of using working cash bonds to fund regular programs. Each year, money was transferred from working cash to the education fund, because the education fund did not generate enough money each year to support the annual expenditures.

With the elevated EAV of Charlottesville, it seemed like a good time to take on the building project. More money was flooding in and the district saw this new revenue stream, even with the building, as a chance to stop borrowing money. After all, the elevated value of the station would seem to indicate that Southtown Power had no intention of leaving. It had been reported to the board and superintendent that the Charlottesville Station was the most valuable plant that Southtown Power purchased from Next Gen Power. Remember, Charlottesville was one of several plants that were purchased at the same time. As the superintendent himself said:

The reassessments had come through approximately...this was like I said a chance for us to quit borrowing money...so we were able to basically level our tax rate...It was a conscious effort on the part of our board and 
myself to take a look at what we had and use what we have coming in rather than having to go through debt.

Laura, the board president, seemed to feel that this new stream of money was going to aid the district in its ability to take care of building needs and allow them to stop its indebtedness at the same time. Previously, the board had planned to renovate the building over a period of fifteen years. But with this newfound revenue, those plans could be accelerated.

There were some things that needed to be done to that building if we were going to be able to stay. Then, Charlottesville sold to Southtown Power, and sold for an inflated price, but our thinking was, my Lord, if they paid that kind of price for it, they must be staying. And, so, we all of a sudden had an influx of money through the elevated EAV, so we thought, let's get this building done. So, instead of doing it over... we had a plan in place where we were going to do it over a period of fifteen years. Well, here, now was an opportunity where we could get some of the important things done, and not have to wait on some of the things we thought needed to be done.

In a close analysis of the high school district's finances, the records show that the high school was, indeed, eliminating its debt. As the superintendent stated, this newfound revenue stream allowed the district to buttress the education fund so that regular revenues slightly exceeded regular expenditures. This was a positive turn of events for District 39.

Storm Clouds Approaching...Charlottesville Station is Rumored to Close

In order to understand the context under which rumors began to circulate, it is important to understand some details surrounding the sale and taxation of Charlottesville Station.

When Next Gen Power Company (an electric generating and distributing power company that owns many different power plants) sold Charlottesville Station to 
Southtown Power (a different electric generating power company) in 2000, part of the purchase agreement called for Southtown Power to sell the power they generated to Next Gen. This arrangement expired in 2003. When the power purchase agreement expired, Charlottesville Station no longer had a buyer for the power it was producing. The oil burning method of generating electricity (which was the method used at Charlottesville Station) was more expensive than nuclear generation, and there are two nuclear power stations located within fifteen miles of Charlottesville Station that produced cheaper power.

A second problem was that Haynes County, where Charlottesville Station is located, is the only county in the state that has a machinery and equipment tax. This tax makes the taxable value almost double what the taxable value of an identical plant would be in the neighboring counties. This extra tax, combined with the expired power purchase agreement, combined to force the officials of Southtown Power to strongly consider closing a plant they purchased only three years earlier.

In 2003, representatives from Southtown began to grumble that they were not able to make Charlottesville profitable. Some in the area began to hear that Charlottesville might close. One board member, Wanda, had a husband and nephew who worked for a neighboring power plant owned by Next Gen (the company that had previously owned Charlottesville) and they had heard these rumors.

My husband was an employee of Next Gen power, not there, but at another station, so, of course, the rumor mill constantly goes amongst the plants, and he had indicated that it looked like they were going to close down. And then I had a nephew working there, too, so he was concerned about his job, so there was some background knowledge that wasn't for 
sure, but there were rumors stating that this was going to happen, it wasn't going to happen.

But Tigertown is a relatively small town, and rumors can spread easily. It is quite possible that many people heard the rumors, but, considering Southtown Power had paid so much for the plant, most people discounted them.

Charlottesville Station representatives were upset with many factors that dealt with the profitability of the station. Despite their protestations, the taxing bodies didn't believe Southtown Power when they said that they couldn't afford to pay its taxes. The taxing bodies' incredulity was based on a few historical factors. First, as reported earlier, it had only been three years since Southtown Power had purchased Charlottesville Station. Second, the taxing bodies had grown accustomed to the officials at Charlottesville Station protesting their taxes. And third, the officials from Southtown Power even admitted that the taxes weren't the largest issue for them...it was the fact that the power purchase agreement had expired and they had no one to buy the power that they were producing. But, as Mr. Johnson said, it was still important to try to maintain a positive relationship with Southtown Power. After all, Charlottesville did provide approximately $45 \%$ of the school district's property tax revenues.

Even so, it is best to make plans for the worst. So Mr. Johnson began to plan for a life the district did not want to live... a life without Charlottesville Station. "[W]e knew something was up, so we were reading the tea leaves and basically beginning to plan for the loss of this revenue." It is important to mention here that Mr. Johnson went about his plans without informing the board. At that time, no board members were made aware of Mr. Johnson's fears. 
Mr. Johnson's plan was based on an examination of the entire seniority list in the district. He saw that several faculty members would be retiring by 2006 . He saw staff attrition as the preferred method of reducing the district's budgets. He also created a new five-year revenue and expense forecast based on the closure of Charlottesville Station. That forecast showed that the district would be able to make minimal cuts to its programs and, assuming typical EAV growth in all other property, would be able to maintain all current programs, but that some staff positions would have to be eliminated. In addition, the district would be forced to begin charging fees for extra-curricular activities (known as "pay to play") and the district would also be forced to charge students a fee for taking classes at the area vocation center. But since the plant was still open, the plan would not need to be carried out. The reduction plan would only need to be enacted in the event of Charlottesville's closing. And while the plant was open it was also important for Superintendent Johnson to maintain close ties with representatives from Charlottesville Station, in order to be kept abreast of the plant's future viability.

One way that the district attempted to maintain a positive relationship with Southtown Power was through attending negotiation sessions with the plant. The power company requested that meetings be held, and all taxing body representatives were invited. Superintendent Johnson summed up the negotiations with Southtown Power, where plant officials admitted that the plant's property tax bill, while an important factor, was not the primary reason for the potential closure:

We met as a joint Board with the school boards and officials from Southtown Power and basically heard their plea to consider their dire straits and at that time what came out was the worldwide economy changed significantly and impacted their power purchase agreement with Next Gen. It no longer was in existence, so they had no one to buy power that they were generating. There were five things that came out of that 
meeting. We weren't number one...the tax rates from the school districts was not the issue... but it was these other extraneous things that happen outside in the world that we had no control of and quite frankly they didn't either.

\section{Building Open House}

In the early months of the 2003-2004 school year (a year prior to Coach K's retirement), more and more rumors began to swirl regarding the potential closure of the plant. At approximately the same time, the school district held an open house for its renovated facility. To recap, after the sale of Charlottesville Station in 2000, district officials decided to stop borrowing from the working cash fund to operate its regular programs. The district also accelerated their plans for renovating the building from a plan that would have spanned fifteen years to a plan that spanned three years. The influx of revenue as a result of the sale of the plant had freed up additional funds to fulfill both goals. The renovations were concluded in the fall of 2003. Announcements for the high school open house were placed in the district newsletter and in the daily newspaper in town. The board felt that the community would want to see the renovations that had been done, and the board also knew that they had spent nine million dollars on the renovation, so it was logical to assume that people would be interested. The night of the open house, the board found out that there was, in fact, little interest in the project. Board President Laura remembers this bitterly:

[W] had this remodel done on the school, we had this wonderful open house planned, and we invited the whole community and we had twelve people come. Twelve people, and we spent nine million dollars! Why wouldn't you want to come and see that?

This evening left a sour taste in the mouths of the board and administration. They had spent millions of dollars and countless hours working on the building and only 
twelve people came to see the end result. In hindsight, though, it may not be that surprising, considering the fact that only two or three people showed up for the meetings when the project was planned, or when the bids were let out, or even when the bids were accepted. In fact, according to the board and administration, there was almost never a turnout for any board meeting that took place. The only board meeting that was well attended was in the winter of 2005. It was a special meeting that was called solely for the purpose of hearing from the public regarding Coach K's desire to remain athletic director. The meeting was so well attended that it was moved to the high school gymnasium. That meeting will be discussed in the coming pages, but for now, the issue at hand was the fact that the rumors of Charlottesville's closing would soon be proven true.

\section{Charlottesville Station Closes its Doors}

It was wise to begin planning for the closure, as Wilbur Johnson had done, because in 2004, Southtown Power announced it would, in fact, close Charlottesville Station in 2005. The full effects of the closure would not be felt for two full school years. As was illustrated in Chapter II, the system of property taxation in Illinois calls for property taxes to be paid in one calendar year, but those funds are not dispersed until the following calendar year. In the case of Charlottesville Station, the plant would remain open through calendar year 2004 and halfway into calendar year 2005. As a result, the district would still receive property tax revenue from Charlottesville Station until calendar year 2006. Considering the fact that the station only remained open for a portion of 2005, the tax bill to Southtown Power would be considerably less than the bill that was paid for 2004. This resulted in a ramp down of the property tax revenue received by the district. 
As previously mentioned, rumors of the closing had been floating around the community, but the board of education and community were stunned. When asked what her response to the closure was at the time, Gayla, a board member, put it simply. "Oh no! It was just doom and gloom, and everyone said the school is now going to go to pot." The board president, who said she learned of the closure from the superintendent, remembered that the community immediately turned to the school and began pointing an accusatory finger. Community members felt that the school district should have seen that the plant was going to close. And when you consider the fact that the school district had just recently spent nine million dollars renovating the high school, many in the community now felt that the district officials had been wasteful. They felt that the money used for renovation should have been saved to protect the district in the event the plant shut its doors. Laura recalls:

They felt, for some reason, we should have known that the plant was going to close. Back to my other statement, we figured since they paid such a huge price for it, they were going to be here. So it didn't make sense to me that we should have had any kind of ...you know, the crystal ball wasn't lit up, we didn't have any kind of idea. It was money we were going to spend over a period of time anyway, so it was...it looked like we were out spending every buck we had [in reference to the building renovation]. I think certain people in the community thought that we should have had some kind of foresight that that was going to happen. And, the fact that we didn't, you know...they were disappointed; however, at our board meetings, when we signed all the paperwork to do all that big remodeling, we had, maybe two people in attendance. So, we always heard about it on the back end, you know, shoulda, woulda. If we could have known, that would have been something we couldn't have done, of course. But we didn't know, and we were in the middle of it when it happened. And Mr. Johnson called and said, oh boy, guess what we just heard. So, myself and another board member came in and we talked about it...there was really nothing we could do at that moment but present it to the rest of the board. 
Board member Gayla remembered the community's response this way. "The District is going to go to pot, and we don't know what we're going to do, and people in the community were getting upset and were saying, well, you had all this money all this time, why didn't you put some of it away?"

\section{Learning to Live with Less}

The board began meeting in earnest to determine what expenditures could be cut in order to make the district financially viable. At this time, Mr. Johnson's plans for budgetary reductions were shown to the board. Board member Wanda recalled what the board's mindset was at the time.

So, it was like, OK, now we have to seriously look and regroup, because we were not in a borrowing phase. We were in a kind of even keel. We didn't have much in savings, but yet we weren't in borrowing mode. So that, kind of threw us into, OK, now what are we going to do, because we have to make up this funding, plus, at that time, housing was booming, so also we were looking at an influx of students. So, thank God for Wilbur Johnson, he had a good overview of what was going on, and we actually were invited to a meeting with the attorney and we were all at the high school...all the taxing bodies were at a meeting, and we had a group meeting, per se. The attorney went over a lot of the things that were happening out there at the time.

District 39 was fortunate that they had made the decision in 2000 to begin the process to eliminate their operating debt. The closing of the plant, while troublesome, at best, was not going to spell the financial doom for the district. But still, the district knew it would have to cut some expenditures and make an effort to increase revenues, where possible. Board member Cal put it this way. "As I recall, we were in the black, or close to the black, so we knew we had to go into deficit spending. So, we looked for things to cut." 
Board President Laura said that the board looked to Mr. Johnson for guidance.

She remembered that the board, through Mr. Johnson's recommendations, placed a high priority on being as financially transparent to the public as possible. Board members were hopeful that people in the community would attend board meetings so the board would have an opportunity to explain the district's financial situation. In addition, the board did not want to limit opportunities for the district's students; nevertheless, some cuts would have to be made. The board looked at all programs for reductions, but they ultimately didn't feel that much would need to be changed, but they did accept the fact that a few teaching positions would have to be eliminated.

Well, Mr. Johnson really, of course, led that, and his feeling was to be as transparent as we could be... about where we were going to be, and how this would affect a person in a median household. Our first response, we looked at staff, because, of course, when you're paying insurance and everything like that, that's the biggest savings you can make. So we looked at our extra-curricular programs and looked at staff. We ended up cutting two positions...it was two or three. We had some teachers who were retiring, so we did some shifting. But we had two positions that were in the art field, and we felt we could re-direct students to more core subjects, and it needed to be done anyway, because, it just seemed like we had...I had two students back then that were nearly out of Tigertown High School and I could take from that personal experience what they thought when they went to college...you know, how did they feel they were prepared. I talked to their friends, we did a little survey to try to see where we were weak and where we were strong, so we knew we really needed to re-direct, anyway. [It should be noted that the board president's recollection of cutting teachers in art was inaccurate...no art teachers were eliminated as a result of this process.]

So the board, in a sense, took the new financial situation as an opportunity to more closely examine the school's curricular offerings. Since the district had made the decision four years prior to eliminate its debt, the board didn't feel that drastic changes would be in the offing. Board member Wanda echoed these feelings: 
I think as a full board we sat down and really looked at our curriculum. We looked at our teachers. We didn't really want to trim any programs out of the school that we really didn't need to, and don't think we really did. I think we just tightened the belt any way that we could without cutting any programs. We just looked at what was successful...looked at what was mediocre and what we could change and make better, so I don't think we really, other than internal housekeeping by cutting supplies or some of the equipment we didn't replace. Just making do with what we had.

Since the board did not feel that any particular programs needed to be eliminated, they looked at what paid positions could most easily go. Board member Gayla remembered that attrition and trimming excess paid sponsor positions were the most popular solutions. In fact, she recounted the decisions years earlier to eliminate the French program.

Through the years, we've lost, like, French because of students not taking it as much or low attendance, so we kind of cut back on that. There were teacher cutbacks through attrition...through older teachers retiring and then getting younger teachers in. As far as programs, we cut back some paid positions like, that were for speech team, mathletes. We cut back like one paid sponsor position for each group.

Superintendent Johnson recalled that the administrative team took on the task of detailing what could be cut and how long it would and should take the district to implement these retrenchment practices. The administration felt that extra-curricular programs should be the first areas to be considered for reductions. He also recalled that the teachers were not supportive of any recommended cuts. In the end, though, staff attrition and reallocation, primarily in the driver's education department, seemed to be the most effective means to reduce district expenditures.

We began to meet...the administrative staff began to meet...to come up with ideas for ways in which we could cut back incrementally over a period of years rather than all at once because the ramp down for Charlottesville Station wasn't going to happen all at once, it was going to be phased in over three years. So we prepared a list...well, how are we 
going to do this, and we had criteria where attrition would be our first means of making reductions and tightening of programs reducing the number of games that kind of stuff. On that side we began looking at issues in our clubs and activities. Where can we cut? Well, they didn't want to cut. We said well you have some clubs and activities that may have three sponsors...let's reduce the number of sponsors. So we went through that process. We looked at driver's ed... a huge cost to us because at that time we had five maybe six teachers where three of them were at the upper end of the scale and it was costing us a ton of money and they have a sweet deal where everything was done during the school day and they didn't have to work after hours and they were making huge bucks. We began moving that to after school on the weekends and in the summertime and we began to reassign them to their secondary responsibilities...history, PE, etc.

In the end, the district was fortunate that they had a few senior teachers that were nearing retirement. The district was able to reassign two driver's education teachers to teach physical education and history. Students were encouraged to take driver's education in the summer and fewer periods were scheduled for teaching the class during the regular year.

The driver's education position that was eliminated was the part-time load previously filled by Coach K. In addition, the second band teaching position that was created several years before was eliminated, as well. All told, two full time equivalencies were cut as a result of the reallocation of teachers. Mr. Johnson made reference to the fact that slight alterations were made to the assigning of teachers, and that made sense financially; however, he also made mention of the fact that the teachers didn't like these changes.

In addition, a certain segment of the teaching staff began to bring up another issue...Coach K. did not want to give up his athletic director position. This issue ultimately came to the forefront and caused a great deal of trouble for the administration and board of education. 


\section{Growing Discord among the Teachers}

Board president Laura went even further to express the animosity that was

growing between the teachers and the board and administration.

Our teachers didn't buy in. They just wanted what they wanted. We got nothing...I hate to say it that way, but it's true. They did not see the need to cut back. There was no concessions, in anything. And that was tough to swallow, because I figured, maybe we could have a little community, you know, let's put our heads together and let's cut back where we can, everybody will do their part and we'll get through this. But they didn't have any part of it, so that made it tough. And then that strains relationships, of course, because we were trying to make the community see what we were doing, and they wouldn't even buy.

It should be noted that the district and the teachers were in the middle of a collective bargaining agreement at the time. In order for the teachers to adjust their pay, the contract would need to be opened and negotiations would need to take place. When asked to renegotiate, the teachers declined. When Laura was asked to elaborate on her feelings, she continued:

I think it's the unions. They had no sympathy for where we were coming from. I thought we were being clear, we were being honest, we told them exactly how we thought it was going to be and we asked their opinion... do you have another way to do this? I would love for them to have gotten together as a group and said, you know what, let's just freeze everything, can we keep these two people? That's a Pollyanna view, I know it is, but they didn't care. They wanted more money, and they didn't care that we were having to lose two people because of it. I went home and said to my husband, it's like they ate their young tonight....and that's what I felt like. I don't know, I don't know. A little bit of it is with everything else that was going on at the school at the same time.

The last statement speaks to the issue of Coach K. He, and others, through the teachers' union, were voicing their displeasure over the board's decision three years prior to stipulate that the coach needed to resign his athletic director position upon his retirement from teaching. The board still maintained that Coach K. could stay on as head football 
coach, but that was to be the extent of his responsibility within the school. As previously mentioned, Coach K. led by intimidation and by his mere presence. Many of the teachers on staff simply wished to stay out of the entire situation; however, the athletic department and other veteran teachers in the district, including the senior band director, stood firmly behind the coach and they were speaking to people in the community. By mid-winter of the 2004-2005 school year, right at the time the board was considering cuts due to the closure of Charlottesville, the community was demanding that the board address this issue in their presence.

In February 2005, the board of education met in a special meeting in the varsity gymnasium. This meeting was held to allow the public's input on the decision to contractually bind Coach K. to his resignation from his athletic director position. The gym was mostly full that evening...over 800 in attendance. While not everyone in the audience was in favor of allowing the coach to stay on as A.D., most were. A microphone was placed in front of the board table and people were allowed time to speak in favor or opposition to Coach K. The only people who spoke that evening were those in support of the coach. The board sat patiently and listened, but they never waivered. They held fast to the agreement that Coach K. had signed three years prior. Superintendent Johnson remembered the evening well.

That board, since they had committed to these hefty salary increases, said they were going to stick by it. When the board was confronted in the meeting in the gym, it was all orchestrated by Coach K. and his supporters, but they didn't give in. These people threatened everybody.

At the conclusion of the evening, the board declared publicly that they were not going to change their mind and that they were going to hold to the terms of Coach K's retirement agreement that had been signed three years prior. The board explained that 
some of their reasoning was based on the fact that they were currently trying to cut costs, as they knew their revenue stream was shrinking. By eliminating his driver's education position and shifting that work to the summer, another position would not need to be created. Also, someone who was already on staff could handle his position as athletic director, and that position would not need to be filled. Most of the people in the gymnasium were upset, and the board was certainly aware of that fact. Coach K. was so upset that he resigned his head football coach position as well. This caused even more hard feeling within the community. The board admitted privately, though, that they were ultimately pleased that Coach K. would no longer be affiliated with the school. The board also stated publicly that they had a larger problem to tackle, and that was the problem of how to handle the district's declining revenue as a result of the closing of Charlottesville. The board knew that they had to carry out some unpleasant decisions and they braced for the unpleasantness that they were sure was coming.

\section{Community Pressure...or Lack Thereof}

As previously mentioned, there were some community members who voiced their displeasure at the board for spending so much money on the renovation of the high school. It was believed that the board should have known that Charlottesville was going to close. It is interesting, though, that so few people showed up for the signing of the contract that committed the board to the remodeling project... or maybe it isn't interesting when you consider how many people showed up for meetings after the closing of Charlottesville.

According to the administration and board members, very few people showed up for the meetings when cuts were being discussed. Gayla guessed that, perhaps, five 
people regularly attended these meetings. Laura put the number lower. "Very few community members ever attended. We had a board meeting ... we might have had two or three people at every board meeting...that was it...which was very disheartening." It was disheartening because the board members had hoped that large crowds would come to the meeting, thereby giving the board an opportunity to explain the district's financial situation to them. The board had placed a high priority on financial transparency, but their plan for broadcasting their message was being short-circuited by the dearth of attendees at the board meetings.

When asked if they felt any pressure during that time, the results were mixed.

Board member Cal remembered it this way:

I never felt a lot of pressure from the community to do one thing or another. I'd talk to some people and they would say don't cut programs, but that was never our intention. I talked to people and said we were going to have to set fees, but I would say the majority of the people I talked to said they could live with that, even kids who were participating in stuff.

Wanda indicated that the issues that were arising from Coach K's retirement took more of the board's time than did the issues arising from the closing of Charlottesville. It's interesting that her recollection was that the board did not cut band, because they did, in fact cut one band teacher. It is possible that she is referring to the fact that the program itself was not cut.

Unfortunately, at that period of time, we also had the big issue of the football coach going on, and, unfortunately, that took a lot more precedence than the Charlottesville Station closing, and that's not right, but that was the hot issue that was going on in town at that time. People were concerned about... are you going to cut band? Are you going to cut sports? Which we didn't do any of. But that was pretty much it of the people concerned, because they were all concerned about that other item. 
"That other item", though, seemed to be at the forefront of the community's mind, when you consider Laura's thoughts.

Oh, there's always pressure... about sports... always about sports. We never talked about cutting a particular level of sports, but we talked about, maybe, having there be cuts. At Tigertown High School, if you joined the team, you joined the team...we never cut. So, we thought, well, maybe that would be a way to save uniforms, transportation, that kind of thing, so we thought that might be a way to go. But, we never, ever said we were going to cut a level, and that was the rumor out there...they're cutting freshman sports. It was all about sports. There really was no other pressure about anything else.

Gayla, when asked if she ever felt any pressure to save certain programs, was unequivocal: "Yes, football. Mainly football. They did somewhat cut back, but we had another situation going on at that same time that made it really bad." When asked if she could elaborate on that other issue, she said that she could not. It is important to mention that Gayla is still on the high school board and is, in fact, the president now. Most of the other people interviewed, save Wanda, are off the board now, and Mr. Johnson is retired. Perhaps they feel as if they can speak more freely than Gayla feels she can. It does show that the effects of Coach K's departure are still being felt, even though it has been four years since his retirement. He even lives out of state now, but his influence is still felt in the community.

\section{The Board Takes Action}

The board embarked on a two-pronged approach to regain financial stability: 1 .

Cut expenses, and 2. Increase Revenues. As previously mentioned, the preferred method of cutting for the board and administration was through staff attrition. As teachers retired, some were not replaced. Some teachers were assigned to their second certified position, and, ultimately, two teachers were released. One of the teachers that was 
released was the second band instructor that was hired several years prior. An existing staff member taught coach K's driver's education responsibilities, and those classes were moved to summer school. A separate staff member took on his athletic director responsibilities. In addition, some superfluous paid sponsor positions were cut. The district augmented its revenues via fees for students to take part in extra-curricular activities, they established fees for driver's education, and they began to charge students to take classes at the area vocational center. These cuts and revenue enhancements would certainly help the district maintain its positive financial stance, but more revenue would be needed.

The community voiced its criticisms and concerns about the athletic department, in general, and, specifically, the football program. But the board was mixed on the issue of the existence of pressure from the community. The fact that few people showed up for board meetings would give some indication that the level of community indignation hadn't reached a critical mass after Charlottesville closed.

At the board meetings, the plans being discussed didn't completely deal with cuts in expenditures. They also dealt with plans to increase revenues. Cal remembers where they planned to find the increased revenue.

I know that we decided to charge fees for sports participation that we hadn't charged before. We also started to charge fees for driver's education that we hadn't charged before. We also started to charge fees for kids who wanted to go to Haynes Vocational Center, so things that, previously, we paid out of taxes, we asked participants to take up fees for participation.

Increased fees can help, but more revenue would be needed than those elevated fees would provide. Laura recalled an additional strategy that was ultimately acted upon by the board, the issuance of Tax Anticipation Warrants. 
Our experiences then were, really, trying to figure out how we were going to get...short-term, how we were going to keep the high school open, and then, long-term, how we were going to get out of our debt, because that was the only way out. If we were going to take debt on, what was going to be the goals, how were we going to get out. And Mr. Johnson was really good at educating us, because, of course, all of us came from a nonschool life. Trying to figure out...prioritizing. He would prioritize for us, in his mind, this is what I think the priorities are for the district...this is what they are going to cost. So he was really good about showing us different ways to go...different avenues to take. We had a lot of discussion, and we learned a lot. He was, really, really good about bringing in...in fact, we had a gentleman come in and help us with the sale of bonds. It was actually not bonds, but tax anticipation warrants. What was good about that and what was bad about that and how short-term that was, and what we can do after that. It was really trying to define goals and how we were going to pay for them. And, I think, the one thing Mr.

Johnson always tried, and we tried to back him up on, we tried to be as transparent as possible, so that, if anybody asked, we would have something in place to show them, so that...these are the steps we are going to take. We're going to try to be... by this year, we're going to try to be here.

Tax anticipation warrants are a loan against property tax revenue that you will receive in the coming months. Think of it as a large-scale payday loan. You know you are going to get some money in the near future, and you know how much money you are going to get. The problem is, you don't have enough money to pay your bills from this point to when the tax money is dispersed. So you take out a loan for no more than $85 \%$ of the tax money you will be receiving. Once the tax money comes in, you then pay back the loan with interest.

It is not advisable to continue this practice in perpetuity, as the interest that you are paying reduces the amount of money you can use to operate the district. The board and superintendent understood this axiom, so they endeavored to run a referendum to increase their overall tax rate. Mr. Johnson recalled the outcome. 
We tried a referendum at that time...we asked for 35 cents in the education fund and 15 cents in the building fund. Both issues were defeated by $65 \%$ to $35 \%$.

The defeat is somewhat easy to understand, when you consider that the majority of taxpayers that would have voted on this issue were also asked to approve a referendum for District 208. When Wilbur was asked if he believed running concurrent referenda might have hurt the high school's chances, he had this to say. "That's correct, and a lot of them [residents/voters] are voting that live within the elementary district and so those are the issues of running referenda at the same time." As a result of the failed referendum, the board decided to issue tax anticipation warrants in order to meet their monthly financial obligations.

\section{Reflections}

So, by 2006, the building renovations had been completed for almost three years, the Tigertown High School District had implemented most, if not all, of the cost saving measures they planned. The referendum attempt was soundly thwarted, the district was forced to issue tax anticipation warrants and Coach K. had retired and had become the head football coach at a neighboring school. His tenure there was brief and he ultimately moved out of state.

When asked if he had any second thoughts about what had transpired, Mr.

Johnson responded confidently.

I don't think we could have done anything differently as our decision wasn't from us...it was a corporate decision made at the site because the loss of their repurchase agreement. It was a corporate move out of our hands out of our control and they were trying to posture themselves within the community to make like, well if it hadn't been schools taxing so much or the county charging so much we might have survived, but I have a statement from an official from Southtown Power that stated that their taxes was about the fifth most important reason for closing the plant. 
When asked the same question, though, Laura had a different response. She wished the board and administration had made a larger effort to help people understand the financial reality the district faced. Remember, the board had hoped for larger audiences at board meetings so the board could explain the district's financial situation. When few, if any people showed up for meetings, the board never made any formalized plans for broadcasting their message via other channels of communication.

What would have been great was to have had some kind of a community meeting and said if you are a District 39 voter, come and let's talk about it. Let us tell you what our position is. But, I think, from past history, when we had this remodel done on the school, we had this wonderful open house planned, and we invited the whole community and we had twelve people come. Twelve people, and we spent nine million dollars! Why wouldn't you want to come and see that? So, I think there was a little bit of that, you know, we didn't know how... but I think we could have tried harder there. I think Mr. Johnson put an article in the paper, possibly, about what had happened. But, if you don't get the Tigertown paper, or if you don't read it...you know, I'm sure we missed people. And, as you know, in a small town, one little thing circulates, and pretty soon, that's the truth. Mr. Johnson and I went to a couple of community meetings, where we had some folks out at one of the subdivisions call and want us to come out to a neighborhood meeting. They were up in arms, their taxes were going to go up and they were retired folks and people with young kids. And so, we tried to attend a couple of things where folks had questions, but it was very small-scale.

Wanda agreed with Laura. She, too, wished the district could have been more proactive in attempting to raise the community's awareness off what had transpired and how it ultimately impacted the district.

Sometimes I feel, maybe as a district, we could have been a bit more proactive in terms of getting out to people how this was really going to affect the school district. I think it was hindsight and by that point they were leaving...they were pulling out and we were like, oh my, now we've just got to keep sure we keep everything we have intact. So, I think, probably be a little bit more proactive in the sense of actually letting the community know how this was going to impact the school district. 
Because, to this day, I don't think people really realized to the extent it did.

\section{Review of the Timeline}

In 2000, Southtown Power purchased the Charlottesville Electric Generating

Station. The sale caused the EAV of the plant to rise by over $\$ 100$ million. This EAV spike also caused a spike in revenue (approximately one million dollars) for the

Tigertown High School District. The board decided that they would use that money to halt their practice of using working cash bonds to fund their regular programs. In addition, the board also decided to use the influx of money to accelerate their plans to renovate the fifty-year old building.

At approximately this same time, Coach K. signed a binding agreement with the board that gave him three sizeable raises his last three years with the district. A stipulation of the agreement was that the coach would resign his teaching and athletic director positions, but he would be allowed to remain as head football coach.

In 2003, rumors began to swirl that Charlottesville may close its doors. Superintendent Johnson, along with representatives from the other taxing bodies that derive funds from Charlottesville, attended a series of meetings where Southtown Power officials complained of many factors that were contributing to the plant's inability to remain profitable. Mr. Johnson also began to make plans for the possible closure of Charlottesville Station and to analyze the closure's impact on the district's budget. At about this same time, the renovation of the high school was nearing completion. Also, Coach K. was beginning to publicly voice his displeasure over being forced (even though he willingly signed the agreement, he portrayed the situation as he was being forced out) to give up his athletic director position. 
In 2004, Southtown Power officially announced the closure of Charlottesville. As a result, school officials began to review plans for retrenchment at the high school. Since the board had made the decision to stop borrowing in 2000 , the financial situation was not as dire as it could have been. The Superintendent felt that no drastic cuts would need to be made and that staff attrition would be the preferred method of cutbacks. One of the staff positions that was eliminated was that of Coach $\mathrm{K}$. The teachers' union was growing more and more hostile toward the administration and board. Much of this hostility is believed to be the result of Coach K's ability to manipulate people to support his efforts to break his contractual agreement and keep his athletic director position. This hostility spread to a significant portion of the teaching staff, which damaged the relationship between the union and the board. Since the board and teachers were in the middle of a collective bargaining agreement, it was the union's stance that the contract should not be opened and that their pay raises would still be received the following year. The teachers did not feel that cuts would need to be made.

In February 2005, the board held a special meeting in the gymnasium to hear from the community regarding Coach K's situation. Many people approached the board that evening and voiced their strong opposition to the board's position that his letter of resignation would stand. The board reiterated that the coach could remain as head football coach, but that his athletic director position would be given to another staff member who was not retiring. Out of anger, Coach K. resigned his position as head football coach, further upsetting many members of the community.

All other regularly scheduled meetings of the board, two or three people would be in attendance. The board outlined their plans for restructuring, which did not call for the 
elimination of any programs. Instead, it called for the creation of pay-to-play fees for extra-curricular activities and to attend the area's vocational center. In addition, the board moved most of the driver's education classes to the summer, so the current driver's education teachers could teach other subjects. Also, one of the two band directors at the high school was released, but the band program, itself, was allowed to remain.

The board also attempted a referendum in the spring of 2005. This was done, in large part, because the board was now forced to issue tax anticipation warrants. It is not advisable to issue these warrants each year, as the payment of interest greatly erodes the property tax base over time. The referendum failed, and the board was forced to continue the practice of tax anticipation warrants for a few more years.

\section{Emerging Themes}

An analysis of underlying patterns has provided evidence to suggest several emerging themes relevant to Tigertown High School District 39.

\section{Theme \#1 Established Hierarchy vs. de Facto Hierarchy}

When you retrace the sequence of events well before Charlottesville was closed, or even before it was sold in 2000 , the seeds of discontent in the district had already been sown. There was an established hierarchy in the school district, and then there was a de facto hierarchy...one that was led by Coach $\mathrm{K}$. The coach had cultivated a climate and culture in the community whereby he was able to get board members elected that were sympathetic and loyal to him. The previous administration had allowed Coach K. to do what he wished because they had determined that life would be easier for them if they simply acceded to the coach. 
When Wilbur Johnson came to the district, the board had changed enough that Coach K. no longer had a majority of members that were sympathetic to him. Wilbur was the type of leader that believed that the school district would only be successful if the positional leaders were actually in charge, rather than just figuratively in charge. The board of education was firmly in Wilbur's corner, and this bond between the administration and board emboldened both groups.

\section{Theme \#2 Board/Superintendent Relationship}

Every board member interviewed expressed admiration and loyalty to Wilbur. They all felt that he was financially astute and that he had the best interest of the district in mind when he made decisions. Consider these statements from the board members:

Board President Laura:

Mr. Johnson was really good at educating us, because, of course, all of us came from a non-school life. Trying to figure out...prioritizing. He would prioritize for us, in his mind, this is what I think the priorities are for the district...this is what they are going to cost. So he was really good about showing us different ways to go...different avenues to take. We had a lot of discussion, and we learned a lot.

Board member Wanda:

So, thank God for Wilbur Johnson, he had a good overview of what was going on.

Board member Cal:

The high school district is in pretty good shape. Wilbur was pretty good at managing money and we got into the black.

Shortly after Charlottesville's sale in 2000, it was Wilbur who recommended that the district halt its practice of using working cash bonds to partially fund its regular programs. He was also instrumental in the planning of the building remodeling project. 
The board and he decided that they could accelerate their remodeling plans, due to the extra money that came in on a yearly basis after the sale of the plant. And it was Wilbur who foresaw the closing of Charlottesville and he began plans to prepare the district for its closure.

When Wilbur began examining all the possibilities surrounding Charlottesville's viability going forward, he decided that it would be in the district's best interest to begin outlining plans for how the district would need to operate if the plant closed. One of the more perplexing issues that arose as a result of the research is the discrepancy in the response to when the board members and Wilbur knew the plant was going to close. Some board members said they had heard rumors of its closing, and other said that they were shocked when the news hit. When asked if he saw the closing as an inevitability, Wilbur Johnson had this to say:

So out of that period of time for years we began to hear from them through various conversations that times were tough and getting tougher and that their lease was coming to an end, their lease power agreement they had with Next Gen, which was a part of the sale, so consequently they began putting more local pressure through the [local economic development commission] to reconsider [their tax rate].

In addition, Mr. Johnson said that he had been examining the situation and had begun making plans months before the announced closing. No board member ever stated that plans were made prior to the announced closure. In fact, when further questioning was done to reconfirm this reality, each board member said that they did not begin making plans for retrenchment until after Southtown Power announced that Charlottesville would close in the spring of 2005. It's curious that the superintendent 
would keep such information from the board, especially in light of the fact that Charlottesville accounted for $45 \%$ of the school district's property tax revenue.

Perhaps this all makes more sense when you consider a comment from Wanda, when considering pressure from the community.

I think Wilbur, pretty much, was the spokesman. He handled any questions that came up. As far as I know... he probably could have told you differently, because they would have contacted him directly, more so than board members. He was as vocal as he could be about it. I think he handled it very well. As a board member, I think was pretty seamless in terms of interaction with the community. Maybe Wilbur did and maybe Wilbur didn't. He pretty much handled $98 \%$ of it.

Earlier, Wilbur was quoted as saying the board was very supportive of him. He felt that his influence in the community was strengthened by the board's support of him. Laura said that she ran for the board so Wilbur could be supported. Each board member had great praise for Mr. Johnson and it is clear that they felt and still feel that he did great things for the district.

The last statement from Wanda is telling. The board clearly leaned on Wilbur to guide them through most, if not all issues. Superintendent Johnson did not feel that he needed to inform the board, because they were going to follow him regardless of what happened. He had proven to them, quite possibly through his strong leadership style, that he was in full control of the school district. The board members had no reason to question him, in their minds, as he always had the best interests of the district at heart.

When you consider the work of Chris Argyris as it relates to this situation, what transpired may be even easier to see. According to Argyris, management will avoid looking at situations that may cause stress or embarrassment. In the case of Charlottesville's closing, it could be argued that Mr. Johnson carried out his scenarios in 
secret because discussing the possibility of the plant's closure in public may have caused more people in the community to take notice. It is possible that in Mr. Johnson's mind, he was preparing the district for the closing without having to deal with any potential stressors that would arise as the result of making his plans public. Why bring up the problem if the closure never occurs? District officials had grown all too accustomed to hearing rumors that the plant might close...why was this year any different? Superintendent Johnson said he felt that the officials from Southtown were being honest with him when they explained why the plant was not profitable. But, when considering the context of the situation at that time, the administration and board were already dealing with problems arising from Coach K's wishes to remain as athletic director. It may be as simple as the administration's desire to avoid any unnecessary stress.

So, in the 2004-2005 school year, the board and administration had to make some quick decisions, and they were hopeful that the certified staff would take part in the process of retrenchment. The board quickly found out that the union wanted no part of it. Theme \#3 Plant Closure acts as an Accelerant and Presents an Opportunity

It has been well established that Coach K. had created a de facto hierarchy within the community and school district. For most of his tenure at Tigertown, he was allowed to do what he wished. When Wilbur Johnson took the district's reins, he and the board began the process of taking back the power that Coach K. had wielded.

The administration and board that was in place at the time of Charlottesville's closing, apparently did not wish to accede to Coach K's wishes to break the terms of his contract and keep his athletic director position. In fact, it could be strongly argued that the closing of the plant even provided the administration and board with an opportunity to 
rid them of Coach K. by eliminating his position. As Gayla said, the preferred method of saving money was through attrition, or by hiring young, less expensive teachers when more senior/higher paid staff retire. "There were teacher cutbacks through attrition...through older teachers retiring and then getting younger teachers in." One of those older teachers was Coach K.

According to Laura, many of the teachers were upset, but others simply wanted to stay away from any problems.

We were in the middle of Coach K. thinking that he was getting kicked to the curb, and we were in the middle of all that, and the teachers that had followed him...there was a real division between the administrators and the board and most of the teachers, not all of them. I think some of the teachers just were afraid to say anything.

It's interesting, but all of the interviewees stated that the Coach K. issue was more problematic at the time, as compared to the closing of Charlottesville...more problematic in the sense that the football issue as opposed to the budgetary cutback issue generated more unrest. It is suggested here that the two issues were more intertwined than was mentioned by the interviewees. Much of the teacher unrest, arguably, would have occurred whether or not Charlottesville closed, as there was much history to suggest that competing issues within the district would, at one time or another, have collided. It's just that the closing of Charlottesville happened at almost the exact same time that Coach K. decided to retire. As was argued here, the board simply used the Charlottesville issue as a means of removing the coach. In essence, the closing of the plant accelerated hostilities that had lain relatively dormant while the district was in better shape financially. 
When asked from where most of the pressure came, in regards to protecting certain programs, those who had opinions were unequivocal: sports and specifically football. It has been included throughout this chapter that the Tigertown football Badgers were and are the pride of Tigertown. It is not uncommon for communities to rally around successful athletic teams, and Tigertown is no different.

While one board member mentioned someone wishing to protect band, it was almost as an afterthought. And when you consider that one of the two teaching positions that were cut was in the performing arts arena, you could argue that the school district's decisions of where to cut were in line with what the community valued least. Cal summed up his experiences at that time with the following:

We asked for a school referendum and that would have helped. We had the big thing going on at that time with Coach K.... a big brew ha ha, so that took most of our attention and effort. That was a lot more of a big deal, in terms of time spent, than Charlottesville was. Obviously, Charlottesville was a much bigger deal in terms of the operation of the school, but it seemed to take up less time than the Coach K. thing.

It could be argued that once the community discovered that no cuts would take place in athletics, there was no need for a referendum. When only twelve people come to an open house for a building that just underwent a $\$ 9$ million renovation, yet the parking lot is overflowing on a Friday night for a football game, it is even less surprising that there was much community consternation aimed at protecting academic programs. And when an entire language program, such as French, is allowed to die on the vine, but freshman football is protected from cuts, it is clear that academics often takes a back seat to athletics at Tigertown High School. Ultimately, the successful football coach was pushed aside, but that had more to do with a power struggle than evaluation of a specific 
program. Put simply, band, and foreign language were cut or at least downsized, while athletics was left virtually unscathed.

When considering the research question, (How did the District react to the closure of Charlottesville?) it can be summarized fairly simply. The board wished to involve the teaching staff in the process of determining what should be cut. The teachers were already divided and many distrusted the board and administration due to the issues with Coach K. and his impending retirement. The community, through its actions, had demonstrated that the Coach K. issue was of greater importance than the retrenchment efforts. This left the board in a position where they needed to find some direction, and they looked to Wilbur Johnson to provide the structure for their efforts.

Wilbur had earned the trust of the board during his tenure in the district. He had proven that he was financially savvy and that he intended to empower the board and administration to lead the district by way of diminishing the power that Coach K. had accumulated. He also was wise to maintain close ties with officials from Southtown Power to better determine the fate of Charlottesville Station.

Months before the announced closure, Wilbur began making plans for what cuts would need to be made if Charlottesville did close its doors. When the official word of the closure was given, he already had detailed plans in place that he could use to help guide the board's efforts toward balancing the district's budget.

The board was fortunate that one of the elementary districts in town, District 208, was also going through the retrenchment process, and their actions were drawing the ire of the community. Very few community members ever attended a high school board meeting, and there was little pressure exerted on the high school district board members 
to save certain programs. The only consistent pressure came from people who wished to see Coach K. remain as Athletic Director.

The board held a special meeting for the purpose of hearing from the public on the issue of Coach K. At the conclusion of the meeting, the board said that they were not going to change their minds and that Coach $\mathrm{K}$. would have to relinquish his Athletic Director position. They were thrilled that evening when Coach K. informed them that he would also resign as head football coach. The board was wise to use the closing of Charlottesville as an opportunity to rid themselves of the coach. As Culbertson (1979) said, financial problems enable the board to re-examine issues that they have previously wished to remedy, but were afraid to challenge the status quo. In times of retrenchment, the status quo is already challenged, as financial needs must be met in order to keep the district viable.

Finally, the district attempted a referendum in an effort to make up for the lost revenue from Charlottesville. The elementary district ran a referendum at the same time and both referendum questions were defeated by large margins. After the defeat, the board elected to issue tax anticipation warrants. They knew that they would have to use these warrants for a time, but that they would attempt to do whatever they could to make this a short-term solution rather than a long-term one. 


\section{CHAPTER V}

FINDINGS AT TIGERTOWN ELEMENTARY SCHOOL DISTRICT 208

\section{A CASE ANALYSIS}

Introduction

This chapter will present the results from the case study analysis of Tigertown Elementary School District 208. A detailed description of the study site will be followed by the answers to the research questions as they pertain to the school district. From these discussions, emerging themes will be identified.

\section{Case Analysis II}

Tigertown Elementary School District 208, Tigertown, Illinois

\section{An Introduction to the District}

As mentioned in previous chapters, Tigertown is a community of approximately 20,000. Within the community, there are three elementary districts: Oneida, which encompasses the northern side of town and straddles the interstate, and enjoys the most industrial and residential growth in Tigertown. Ontario is a small elementary district of fewer than 100 students. It sits to the west of town and its students come from upper income neighborhoods that include a private golf course. District 208 is the largest elementary district in Tigertown. Its district borders stretch from the eastern border of Ontario and the southern border of Oneida. It then extends through the older parts of town all the way to the rural areas south and east of town.

The district offers a full complement of curricular offerings for students PK-8. In addition, prior to the closing of Charlottesville Station, the district offered a wide array of athletic and fine arts programs for the district's students. The District 208 band was the 
largest feeder program for the high school band, and the sixth, seventh and eighth grade athletic teams all played full schedules and each team had a full complement of paid coaches.

In the mid 1990s, the powers that be in District 208 decided that the three elementary buildings in the district needed repair. Further investigation showed that it might very well be cost effective to build a completely new PK-5 structure. As a result of this building study, the district organized the Kids 2000 committee. This group disseminated information regarding the desire to build a new PK-5 building, as well as a planned renovation of Laird Middle School. Scott King, the Superintendent of District 208 at the time, recalls what happened.

We had three buildings. One was 100 years old, one was 75-80 years old and a third was about 30 years old. We had to do a life safety study and we found that we would have to spend in excess of $\$ 10$ million on the three buildings. We formed a citizens committee and we had all kinds of people helping, and they studied everything: re-modeling, adding on, doing everything. And they finally came to the conclusion that the best option was to sell the three buildings and build one and combine all of them into one. And this was in 1997 or 1998.

The Kids 2000 Committee had done its part. And in 2000, Centerville School opened its doors.

Centerville School is a large brick and glass structure that is located on the extreme northwest corner of District 208. It has spacious classrooms, two large gymnasiums, and it houses the central office for the district. The board meeting room is a large, carpeted area with a kitchen and office complex. The vaulted ceilings give it a grand look that is both impressive and lavish. The Centerville School houses all of the PK-5 students in District 208. 
An addition was also added onto Laird Middle School, a 1960's era building that houses the 6-8 students of District 208. This building is located very close to Tigertown High School, the building to which all students in town matriculate. All told, the cost of construction and renovation to the buildings was approximately $\$ 24$ million, but the state provided a construction grant for $\$ 6$ million, leaving the taxpayers of District 208 with a bond payment of roughly $\$ 18$ million. This was to be financed over twenty years. All told, it raised the tax rate in District 208 by seventy-two cents. So, a taxpayer with a $\$ 150,000$ home (which was the average house value in Tigertown at that time) saw their taxes rise by $\$ 360$. While those that ran and supported the referendum had no way of knowing at the time, each individual taxpayers' burden was going to go down under what was projected.

Charlottesville Station is Sold and the District Expands Programs

In 2000 (right about the time Centerville School opened its doors), the Charlottesville Electric Generating Station was being sold to Southtown Power. As was previously stated, Charlottesville was reported to be the most valuable station among the several that were purchased by Southtown Power. The exact sale price attached to Charlottesville was never actually determined, but the Haynes County Assessor placed a markedly higher value on the plant after the sale was completed. The increase in EAV lessened the burden of each homeowner in District 208. This is due to the fact that Charlottesville is located within the borders of the district. When the Assessed Valuation increased by over $\$ 100$ million, Southtown Power assumed a much larger burden of the bond payment. In fact, the taxpayers of District 208 saw their tax rate go down by sixtysix cents. In essence, Southtown picked up all but six cents of the original increase in the 
tax rate as a result of the sale. The taxpayers saw their increase go from $\$ 360$ on an average priced home to $\$ 30 \ldots$ a savings of $\$ 330$ a year.

At that time, the board of education was jubilant that the sale would alleviate some of their financial concerns. For years, district officials had been using working cash bonds to partially fund the district's programs. District officials had run several referenda in the hopes of increasing the education fund rate. These referenda were run with the message to the community that if the referendum were successful, the district could stop its practice of borrowing from working cash. Consider then Board President Susan's words:

One of the things that was so hopeful for us when we passed a referendum to build Centerville and put the addition onto Laird was that Charlottesville Station had been sold by Next Gen, as a package deal and it was the gem of five or six plants that were sold in that deal. Now, the problem was that they did not reveal to us what the price was attached to Charlottesville Station. It was one big sale and they would not divide that out and say what are we paying for this and what are we paying for this. But our understanding was at the time that Charlottesville was the best of all of them. So when the county assessor attached a number to it...I believe we thought it was too low, but it certainly was higher than it had been. So we thought that some of our financial concerns were going to be addressed and be bettered by the sale of the Charlottesville Station.

When your district EAV goes up over $\$ 100$ million in one year, as it did in this case, signs of better times would seem to be indicated. Since Southtown paid so much for the plant, it was inconceivable that they would think of closing it down. So, the board decided to embark on the addition of all-day kindergarten, rather than halt the practice of borrowing from working cash. The board's thinking at the time was that, in time, they could stop borrowing, but, for now, they would expand programs. Once again, Susan explains: 
We believed that it would have a significant impact on the amount of money that we were going to have to borrow, and if the plant continued to improve, because it was valuable, that situation would be resolved. And so it would allow us when we passed a referendum (to build Centerville) to do things that we wanted to do like put in all-day kindergarten and some of the other things that we thought we would be able to do.

The reason the district had not yet put in all-day kindergarten was threefold: 1 .

There is a greater cost assumed when you run an all-day kindergarten program as opposed to a half-day program. In many districts this wouldn't be true, because half-day kindergarten students are only counted as .5 students in a district's ADA. By compelling the students to attend all day, you get to count the students as 1.0 students. This effectively doubles your state aid for kindergarten. In District 208's case, they were a flat-grant district. This means that they had such great property wealth, that they only received around $\$ 250$ per full-time student per day. So, in the case of kindergarten, the move from half-day to full-day kindergarten would only garner the district an additional $\$ 30,000$. When you consider that the district would have to double its teachers in kindergarten from three to six, the costs would far outweigh the added revenue. 2 . The district had been using working cash bonds to operate its daily activities. This means that they were borrowing money on a yearly basis to simply run the programs they had in place. 3. Prior to the construction of Centerville, no district building had the room capacity to add extra classrooms of students. In a half-day program, you only need half the number of rooms as you would in a full-day program, as each room is used by two different groups of students in a half-day program.

The district, then, made a conscious decision to expand programs, specifically moving to all-day kindergarten, as a result of this influx of money. As previously stated, district officials felt that the sale of the plant would help them in their efforts to expand, 
as the district's EAV was assumed to be on the rise. There was no effort at that time to eliminate the practice of using working cash bonds to operate the district's programs. As Susan had said earlier, though, they assumed the rising EAV in the district would eventually allow for that to happen.

Storm Clouds Approach...Charlottesville is Rumored to Close

In 2003, rumors began circulating around the community that Southtown was unhappy with the lack of profitability of Charlottesville. As was reviewed in Chapter IV, there were many reasons that the citizens and district officials chose to largely ignore these rumors. Superintendent King made reference to one of the reasons they didn't buy into the rumors...the plant always contested its taxes and they felt that this ploy was no different.

They would always protest their assessed valuation and we would obviously hire someone to fight that protest with someone who is familiar with industrial assessments.

This was a yearly occurrence in the life of the district. Each year, representatives from the power plant, whether it was owned by Next Gen or Southtown, appealed their tax bill to the Haynes County Assessment Board. The district grew very accustomed to hiring an attorney to aid them in defending the value of the plant, or even arguing that the value of the plant should be higher. The fact that Southtown was once again appealing their taxes was not unexpected. But what Superintendent King saw first-hand was.

\section{The Closing of Charlottesville}

Superintendent King was accustomed to hearing the rumors. In fact, he made mention of this all-too often occurrence when he described a meeting he attended that was hosted by officials from Southtown Power. The intent of the meeting was to discuss 
the plant's difficulties in remaining profitable. All taxing bodies that derived revenue

from Charlottesville were invited.

We had heard rumors that they were going to close and a year or maybe a year and a half before it all took place, we had heard the rumors but nothing really happened. Then all of a sudden through the Haynes Economic Development Counsel in various meetings that myself and the high school superintendent attended, we found out that this is going to be serious and it was going to happen. We set up actual meetings with representatives from Southtown Power and they flew in their corporate representatives from California to talk to us.

When Scott got to the plant in the fall of 2004 (this was his first visit, as he had not been previously invited), he saw that this time, the rumors were true:

We had heard the rumors but we hadn't been out there. While we were out there, we actually observed that they dismantled all the boilers in the plant, so we knew that obviously they dismantled them to prove to the assessment board that they're no longer functioning so they can't tax them. A series of things occurred and they just continued to just totally dismantle the plant and they notified us probably somewhere in October 2004 prior to the March that they were going to totally shut it down.

Scott immediately called his board president, Susan, who happened to be out of town on vacation. Susan remembered the situation very well:

I happened to be at my cabin at Boundary Waters in Minnesota when I got a phone call from Scott King who said I hate to ruin your vacation but the word came down this morning that they were going to close Charlottesville Station.

When asked if she had had any prior warning that the station might close, Susan was almost certain. “Maybe I'm wrong about this, but I don't remember hearing anything." Board member Ted, who works at a neighboring power station owned by

Next Gen, when asked if he had any prior warning, had this to say:

I don't have a very good recollection then. I think I read about it in the newspaper reports. I work for Next Gen and I remember when Charlottesville was sold to Southtown Power. I read the newspapers but it could have been from the superintendent knowing some things because 
of the lawyers. We had been working on the taxing of Charlottesville Station...they were always under litigation so it might have been from an update on that.

Ted's recollection seems to fall somewhere in between Scott's and Susan's. While Ted worked for an electric utility, he certainly did not have any inside information and seemed to rely on newspaper reports, just like most citizens would. He made reference to the ongoing litigation regarding the plant's value, as Scott had done, yet he didn't seem to indicate that he had much foreknowledge of the situation.

Board member Carrie had a slightly different, yet similar memory of what transpired. She recalled the disputes with Southtown over the value of the plant, and she also knew of the power purchase agreement that played a large part in Charlottesville's demise.

The Board President or Superintendent told us at a meeting. We'd always had disagreements through the years about the assessments disputing the value. And when Next Gen sold to Southtown Power, we felt that would give us a better idea of their true value based on the purchase price, but Southtown kept telling us it wasn't worth what we thought. We could never find out exactly what they paid for it and at some point Southtown Power decided to close because they were selling electricity to Next Gen and it would cost them more to produce than they were making and so they decided to close. We didn't really think they would do it, but obviously they did.

Carrie's thoughts echo much of what was illustrated above, yet she remembers being told in a board meeting. Carrie made reference to an issue that was discussed in Chapter IV, the issue of the power purchase agreement's expiration, which was a major factor in Charlottesville's closing; and she also made mention of the fact that district officials had grown accustomed to Southtown objecting to its taxes. While each board member had a slightly different recollection of how they learned of the closing, everyone can remember clearly what impact the closing had on the district and their lives. 


\section{Escalating Tax Burdens}

Board President Susan returned home from her trip so she could quickly aid in the decision-making process. While many issues would need to be discussed, there was one issue, in particular, which needed immediate attention...the building bond repayments and how that would impact the homeowners.

The first thing, I think, we really looked at was what was it going to do not only financially to the district because we knew that certainly would have a significant impact and began looking at programs that would have to be cut. But the real thing I think we addressed immediately was what was it going to do to the taxpayers in this district, because we could cut programs... we could do that and take that money away, we could not take away the building bond payments. What we were going to have to pay...still going to be able to pay. So the assessor was still going to be able to access that money. So, people's taxes...that's when Scott and Karen (the business manager) began doing some calculations...estimating what that was going to impact the average tax payer. Because that burden...if I remember right in closing the plant it was somewhere around, I'll be conservative, it was about $45 \%$ of our income. So what was it going to do to those building bonds, and the burden that it was going to shove on the taxpayers was going to be so significant and we felt it would actually put people out of their homes. So that's when we began to look at the options.

At the time of Charlottesville's announced closure, Centerville School had only been open for four years. The payment schedule called for a twenty-year payback on the bonds that funded the construction. District officials quickly understood that a significant portion of the revenue for repayment was going to disappear. As Susan said, Charlottesville paid roughly forty-five cents of every dollar spent on the bonds. Since bond payments needed to be made for sixteen more years, that burden would be passed on to every other taxpayer in the district.

The year of the announced closure, 2004, the total tax rate for District 208 was 2.7935. In order to make up the shortfall in bond payments, the tax rate rose dramatically 
in 2005 ... all the way to 3.3941 . By 2006, when all of the EAV for Charlottesville had vanished from the tax rolls, the rate climbed much higher, to 4.3577, a two-year increase of 1.5642. Using the same $\$ 150,000$ home, the tax bill increase for that two-year period alone was $\$ 782$. This new heightened bill was actually less than what the impact would have been if not for the much-criticized efforts of the board and administration to lengthen the term of the bonds to expire in thirty years. Susan explains the thinking at the time:

Now we have been highly criticized since then for restructuring those building bonds because we knew, I mean, we knew...they make it seem like we didn't know what we were doing. We absolutely understood that over the term of those bonds, we were now going to spend more money. It was simply the difference between could you afford a 30 year mortgage or a 15 year mortgage and we all know we would rather pay cash for our homes. We know we can't do that. So, you look at when you can reasonably pay off your debt and make those payments. And so you know if you take out a 30 year mortgage, obviously, it's going to cost more money to the bank, but that's the way it is. We understood that fully. As we were having to look at taking on the burden of $45 \%$ drop in our income...not all that because we knew we could eliminate some programs. If I was going to have even a $\$ 2000$ increase in my taxes and people that were on fixed incomes we knew no way...no way could that happen. And so, we restructured some of those bonds so that we could push the impact down the road so it wouldn't be so significant to people.

The board made a very difficult decision to refinance the building bonds for Centerville and Laird and lengthen the term. Originally, when the bonds were sold in 1998, they were set to retire in 2018, as the district taxpayers' bills were being held at a lower level as a result of the value of Charlottesville Station. When Southtown Power could no longer be counted on to pay for any of the bonds, the district officials were fearful that people would be forced out of their homes as a result of the spike in their property tax bill. Consequently, in 2005, the board refinanced the term of the bonds to expire in 30 years, or 2035. So, in essence the bonds were extended 17 years, as a result of adding ten 
years onto a bond payment schedule that was already in its seventh year. This made the community very upset. The community was incredulous to hear that district officials were actually going out to raise the interest rate on the bonds that were sold. Karen summed up the feelings at the time:

One thing the board did do, which in the end result later they were terribly criticized for is our bonds for the building. We refinanced and we knew that the rate was going to go up. You only refinance to get a better rate, but this was to save people's homes so that they weren't taxed out of their homes, so we elongated the payment schedule and, you know, like we said, in retrospect we received horrific criticism for that, but I don't think most people understood the reason that the board did that. And so what it did was reduce personal real estate taxes because, of course, what Charlottesville paid was now on the backs of the taxpayers and they really didn't understand what it could have been like.

As if that wasn't enough trouble, the district also needed to quickly determine how to slash expenditures, as Southtown's tax payments were a significant portion of the district's revenue. It was quickly discovered that approximately two million dollars of yearly revenue would vanish as a result of the closure. Meetings with staff and administration were held to explain the district's weakened financial position. Scott recalls the process:

When we found out that they were definitely closing and what impact that was going to have upon it we set out upon a very sequential process by which we met with staff, we met with the principals on all of this... first of all the board said we had an idea of how much we're going to have to cut and it was horrendous. We were going to be losing in excess of close to $\$ 2$ million in revenue... that's horrible.

In 2004, the year of the announced closure, the district was running a budget of almost \$15.5 million. Even with all of the revenue from Southtown, the district was still running a deficit budget of over $\$ 2$ million. As was previously mentioned, the district had gotten into the habit of using debt (working cash bonds) to operate its programs. As 
was also previously mentioned, district officials assumed that rising EAVs would allow the district to eventually halt this practice, so instead of using the influx of money (after the sale of Charlottesville in 2000) to eliminate debt, as the high school district had done, the district elected to expand programs, on top of constructing a new school and remodeling another school. When the announcement of the closure came, it became evident very quickly that the district was going to lose an additional $\$ 2$ million in revenue the first year after the closure. Quick action was needed.

\section{Retrenchment}

Beyond the issue of escalating tax rates, District 208 had a spending problem. The District was going to have to determine a way to cut expenses, and do it quickly. The board had a great desire to keep the core academic curriculum intact, but it was going to be difficult to determine how to even keep the core and keep class sizes to a manageable level. Board member Carrie had this recollection:

If I remember right, we asked the administration to come up with multiple scenarios, prioritizing to them what things they thought were most important and we knew personnel was going to be the biggest expense, therefore, the biggest cut. But we really felt strongly...there were certain issues like kindergarten class size and certain academics that we felt very strongly about that we asked them to keep in mind when they made their recommendations. And based on our priorities, we went through several scenarios, trying to come up with one that was never the best scenario, but was at least the least harmful scenario.

The administration was asked to create multiple scenarios from which the board could choose. Board member Ted concurred that class size was important, as was keeping the core curriculum intact. Ted also recalled that sports and music would have to be cut in order to maintain the board's priorities.

We wanted to maintain the core. We had an idea of looking at the student population per classroom...classroom size. We wanted to maintain at 20- 
22 but we knew that wasn't going to be possible, and we knew the classrooms in the new building had a maximum occupancy of 28 so we began to look at reducing the staff. We looked at tenure for teachers and the seniority list; that's where we started to cut in the core. We did make cuts in sports and music and that was really, believe me, a tough thing because I have two daughters who went to the district and it was a tough decision that we decided to cut the specials for the arts and music programs and the sports.

The board knew class sizes would rise to an almost unacceptable level, and they also knew that entire programs would have to go to be able to make deep cuts. As Ted said, it was getting very difficult.

District 208, in the first year of cuts, went from a staff of 178 to a staff of 169.

Class sizes rose and programs were cut. Susan remembers one program elimination, in particular. The recently added all day kindergarten program was added to the list of cuts.

We took out all day kindergarten, which was a costly program so we eliminated that. And I understand about how the average daily attendance and all that other stuff, I understand that, but at the time, the money just wasn't there, so we eliminated all-day kindergarten and the extracurricular activities. Those were the two main things we did and band and chorus to keep our core curriculum as it was.

The board ultimately chose to eliminate all day kindergarten, all extra-curricular activities, and the least senior teachers were let go, making class sizes rise. In addition, band, choir and art, three curricular programs, were completely eliminated. The board knew that the community would not be happy. While Susan remembered the consternation over all-day kindergarten, what most other people remember was the community's unrest over the elimination of extra-curricular activities. Carrie shared her feelings on the issue of community pressure in regards to protecting programs and the direct question of whether or not that pressure existed: 
Unfortunately, yes, and the reason I say unfortunately is because people were more concerned about their coaching and their sports than they were about the academics.

While Susan was more personally concerned about all-day kindergarten, she had a similar recollection regarding the community's concern:

When we found the parents come to the meetings and start protesting about the cuts, particularly extracurricular activities...it's funny how that's it...it was more like it was providing a babysitting service, and so they were concerned about not having that babysitting service.

Ted agreed with Carrie and Susan:

Well, yeah, I mean I never got approached personally; it was always at the meetings as a board. We didn't want to cut anything but the town seems to be sports minded and they didn't want to get rid of that. Also a number of people didn't want to increase the population in the classrooms.

So, apparently, the board felt that extra-curricular programs were a priority of the community, but the administration had a slightly different experience. Consider Business Manager Karen's response to the existence of pressure: “Yes, they didn't want any of them (programs) to be cut. They wanted it all but they didn't want to pay for it." Superintendent King's memories are different from all the above comments. He doesn't recall any organized pressure, only shock.

Not an organized pressure, because of the shock that came. I think after it was all said and done there was some pressure, for example, to bring back the all-day kindergarten program and those kinds of things. But at the time it was like when they heard the numbers and they realized what we had to do there wasn't a whole lot that they could argue about. Obviously there were people who had strong feelings and afterwards I heard through the grapevine because I was gone that they had some strong feelings about not doing what we did, but did they present an organized effort toward saving anything? No, not at that time. It was interesting; I was surprised.

All of these individuals have different memories and experiences regarding community pressure, but that is understandable. The administration experienced more 
day-to-day interaction with people at school, while the board members only formally

dealt with these issues one time per month. The rest of their interaction with the community came by living and working in Tigertown. While each person had a different version of what type of pressure existed, they all agreed on how the pressure was addressed.

\section{Community Resurrects Athletics}

During the spring of 2005, the Tigertown District 208 school board held many board meetings that were attended by tens, if not hundreds of people. Not only did the board have to let the community know that their taxes would rise sharply due to the district's reduced EAV and their commitment to bond payments, they also had to confront the issue of larger class sizes and the elimination of programs. In all, the board chose to eliminate all-day kindergarten and revert to the half-day program they had had before 2000. They also eliminated band, choir, art and athletics. As mentioned above, the board seemed to feel that the pressure from the community was aimed predominantly at the elimination of athletics. That feeling may have come from the fact that an organized group presented the board with a plan to save the athletic programs. Board member Carrie summarizes the issue:

The first year of the layoffs included all extra-curriculars and a parents' organization ended up being formed to save them (athletics). And it was kind of an argument among the board to let them do that or not. Because we felt strongly that we couldn't pay for it, yet there were music and other programs that no one stepped up to save. We had overwhelming, no seats, all crowded rooms because they were concerned about sports. And we understood that people were angry, but they seemed to be more angry about sports than about the teachers. We still had to cut some teachers, but that first year it wasn't as many. And it was just disappointing, it was almost like we wanted to say, hey, we laid off some teachers, does anybody want to talk about that? We understand that sports and extra- 
curricular activities are important, but the stuff that goes on in the classroom has to come first.

An organized parent group approached the board in late spring of 2005 in an effort to save the athletic programs. They proposed that all athletics could be run outside of the purview of the school and that all coaches would volunteer their time and parents would pay for officials, scorekeepers, uniforms, etc... all costs associated with running athletic practices and events. The only expense the school district maintained, apart from the utilities in the building and the upkeep of the grounds, was they retained an athletic director. But this became problematic. It was the board's intention to have the athletic director oversee all of the sports and to make sure the games were scheduled without conflict, but since the coaches were not employees of the school, the athletic director did not have much control over what they said or did. Ultimately, though, the board relented and allowed the parent booster club to take on this project and athletic seasons were never cancelled as a result of the retrenchment process. As Carrie alluded, no organized effort was made to save any of the other eliminated programs, such as band, choir or art, but a few people did volunteer their time to see that some attention was given to band and choir. Susan remembers:

Music and choir, we had some other people, and that was still...that was handled differently. They had a pay-to-play thing, where they had a band that was set up. There were some people that still took some lessons. They put together a sort of community band to just keep the flavoring and interest just high enough that it didn't completely just disappear.

Beyond the idea of establishing pay-to-play for band and choir, where lessons were given and a community band was created, one building principal took matters into his own hands to make sure other children could have some exposure to music, as well. In the Centerville School, the Principal organized and ran a winter and spring concert for the 
children (this program was not among the fee-based programs mentioned above). While it was not as large a program as the children had had in the past, it was at least an attempt to salvage something from the cuts that had to be made. While all of this activity was occurring, a separate form of pressure was being exerted on the board and administration, as well...increased scrutiny of expenses.

\section{Scrutiny}

Scott King stated that there was not an organized pressure from the community to save certain programs (which has been debated here), but he did feel pressure from an organized group. This group was a collection of business people from the community that wished to see the district's financial records. They spent a few months poring over financial records and reports. Scott remembers:

There was a group that was put together by the economic development committee that was put together to look at our entire operation to see if we were doing anything wrong, to see if we had mismanaged money and all that stuff. And they spent a long time looking at every single thing we had done through looking at our paper records because one of the things that I said you look at us for four months upside down and backwards and you haven't spent five seconds looking at our classrooms to see what we do on a day-to-day basis. And their response to me was we didn't want to get emotionally involved. I was at a point in my career where I could say anything I wanted to say and I did and I just could not understand that, but the long and short of that is that was published...it was in the paper...there were a lot of articles written about it and basically they found that we didn't do anything wrong. But they just disagreed with what we did; they disagreed with how much money we spent over the years doing the things we did. That's kind of like being a Monday morning quarterback, secondguessing everything you've done. When all of a sudden you don't have to deal with it at the time.

This economic development group did, indeed, publish an article in the paper. It was asserted that the district did not conduct itself illegally or improperly; however, the group issued a strong objection to the fact that the district had grown so accustomed to 
borrowing money to operate the district. While the superintendent was not specifically blamed, he felt that the burden was being placed squarely on his shoulders. "Being the person in charge and responsible for all that, the fingers got pointed in one direction, which I expected, and you know you deal with that."

Board President Susan had a more difficult time controlling her emotions when she recalled those difficult months.

I would break down and cry at meetings, because it's not like I didn't feel the effects of what was happening. A lot of frustration; a lot of really not knowing what to do. If I thought there was something we could have done something differently, we would have done it...I just didn't know. There wasn't a whole lot that we could do.

When asked her opinion as to why she thinks the community turned so much of the blame for the district's economic plight onto the school board and administration, Business Manager Karen did not hesitate:

I think some of it was disbelief. They had had this power plant pay the bulk of the way for so many years that it was an expectation. It was kind of like social security. People look at it as a right and a privilege, and again I think it was disbelief that it was really going to happen...you know, why would a company buy that place and then in just a few years later turn around and say, you know, this is really a bad deal, we shouldn't have done that.

So, rather than blame Southtown Power for making a bad investment, the district officials at District 208 took the brunt of the community's frustration. Most of the time, these officials were able to understand the community's feelings, but sometimes, their emotions got the better of them. Ted recalls one particularly contentious evening when he finally confronted a community member at a board meeting:

I think at the time I was probably about half way through my term...well, I guess it was right before I left. I was a little more confident as a board member, so I could speak up a little bit more... not to be confrontational to some of the members in the audience. They were asking us to do different 
things or wanted to see different things or asking why you didn't do this before, and it was almost my last meeting there was a gentleman there who had been to a lot of our meetings who asked good questions most of the time. It was after the meeting, I was confrontational, I didn't back him into a corner, but I was confident enough to tell him he had all his information he was asking me for. I tried to conduct myself professionally in the business meetings. When we did have people there, we tried to address the audience in a non-confrontational manner. We did have some other meetings that were spirited. It was a tough time for the community, and we were doing the best we could.

By the spring of 2005, the school board had considered and implemented approximately $\$ 800,000$ worth of cuts to the education fund. They had endured heavy criticism for refinancing the building bonds so that people would not be taxed out of their homes; however, even with the elongated schedule, tax bills climbed quickly. Given this reality, what the board did next seems strange.

\section{Attempted Referendum and its Aftermath}

The board attempted to run a referendum to raise the tax rate even further. With

all the difficult decisions that they were forced to make, it seems curious that this

decision was made, but Karen explains the board's mindset that the staff needed to see an effort on the part of the board that something was done to try to save the programs and teachers that had been eliminated.

We did a referendum, but it was pretty much just one to...there wasn't a whole lot of push behind it because they had done so many referendum attempts that failed, but we had to show our staff that we would go to the public and say if we didn't have this money this is what was going to happen. Actually, Charlottesville gave us money assisting with that referendum. They fed us some bucks...not us directly, but they hired an agency to do that referendum for us. Of course it failed miserably; worse than any of the other referendums.

The board asked for an increase in the education fund to offset the loss of revenue from Charlottesville. As was mentioned in Chapter IV, the high school district ran a 
concurrent referendum for the same reason. The results for District 208 were almost identical to that of District 39: 65\% against, $35 \%$ for. As Karen explained, the district officials were almost certain the referendum would fail, as the past eight attempts (over 20 years) had (save the building issue of 1998), but they felt that they needed to make an attempt for the staff. It is interesting that officials from Southtown Power helped pay for the referendum, which they did not have to do. But even with the added help, the results spoke volumes for the district officials...the community was not in favor of an additional tax increase.

With no hope of an influx of money, the district continued in its quest to balance its books. More cuts were recommended for 2006... an additional \$1 million. These cuts came in the form of additional teacher cuts. Classroom sizes grew even higher and the district continued to struggle to make ends meet. Even with the additional cuts, which now, over two years totaled $\$ 1.8$ million, the district was running a deficit budget. The revenue stream had been reduced by over $\$ 2.5$ million and the district was operating in the red by over $\$ 3$ million. Without the cuts that were made, the district's deficit would have been closer to $\$ 7$ million, when you consider contractual raises for employees that would have been called for, had their positions not been eliminated in year one of the retrenchment process.

\section{Reflections}

It has now been almost four years since Charlottesville closed its doors. None of the board members or administrators in place at the time are still formally associated with District 208, although all of them are still taxpayers in the district. When each of them 
considered what they could have done differently during that difficult period, the answers

are almost unanimous. Susan had this to say:

I really don't know what we could have done differently. I might be accused as not being an out-of-the-box type thinker. I just don't know that we had that many options. We had tried, and when I say we, it wasn't necessarily me...this district had tried eight times or nine times I don't remember exactly...to pass a referendum prior to all of this happening, because you never should be borrowing routinely...I mean, we all know that. But if you cannot get your tax payers to realize... you know, for whatever reason...it wasn't packaged correctly, we didn't explain it right... whatever the reason was...we could not make this community realize that they needed to just increase the tax rate and eliminate the borrowing. And so, the combination of borrowing for your budget and the closure it was like the perfect storm.

Carrie's thoughts are very similar:

We didn't have the power to stop it. It was our biggest source of revenue. I don't know if any district would ever expect for that to happen. Industry doesn't come to the area very much because of the county's machinery and equipment tax. Even if it does, the high school may get it and another elementary school. Our district isn't really in a position to accept other industry, due to our geographical boundaries. Our one hope was that when Charlottesville closed, something might come into that same spot, but we knew there were going to be gaps. Sometimes I don't know if maybe we handled it as far as explaining it to the community better as far as what has been going on historically.

Both Carrie and Susan felt that, perhaps, the district could have done more to convince people that you can't borrow forever and that all those failed referenda in the past were the result of some sort of breakdown in communication. Neither women felt that the district could have done much differently when it came to the immediate response right after the plant's closure was announced. Ted, though, isn't quite as certain.

I don't know how we could have accomplished it, but I think somehow that just retreating back to the core and having no specials, I think maybe we could have reduced everything across the board and still maintained some of that. There was no way of getting around reducing the staff with the way our budget was working. I helped run one referendum and was involved in others but we never did get the results we needed except for 
building the school. If we didn't take the opportunity to run that last referendum the community would have asked why we didn't take that chance. It was a rock and a hard place. I knew it was a no-win situation but in hindsight we could have reduced across the board. You're not going to please everybody at any time but I think keeping a limited amount of specials probably would've at least showed the community that we were trying.

While Ted would have rather cut more across the board in an attempt to save

some of the special programs, Scott had a different regret.

I just wish we had been more aware. The community people, some of the economic development people, were kind of critical of us for not seeing it because they claim that they knew about it a long time before we did; we really didn't. We knew the possibility existed but until they actually started going in there and physically tearing things down...I mean they were still operating and when they did that they did it in a hurry. They hired people and they were in there and so I wish we would have known a little sooner so we could have maybe made better plans. It was a shock to all of us I think, and if people were really truthful they would admit to that.

\section{Review of the Timeline}

In the mid 1990's, district officials organized a group named Kids 2000. This group disseminated information regarding the district's goals of building a new PK-5 building and renovating the existing middle school. The referendum was successful, which is remarkable in a community that had defeated the previous eight referendum attempts.

By the time Centerville School was opening its doors for the first time, the Charlottesville Power Station was being sold to Southtown Power. The sale caused the EAV of the plant to rise by over $\$ 100$ million. This spike in EAV corresponded to an additional one million dollars flooding into the district's coffers on a yearly basis. The spike also lowered the tax rate for the district's taxpayers, who were just beginning to pay 
for the building bonds that paid for the construction of Centerville and the renovation of the middle school.

For years, district officials had hoped the voters would approve a referendum that would have allowed the district to access more money in the education fund each year. The added dollars would have allowed the district to halt the practice of borrowing from the working cash fund each year to fund the district's programs. When the influx of money finally came, not in the form of a successful referendum, but due to the sale of Charlottesville, district officials did not halt the practice of borrowing; instead, they an added all-day kindergarten program, which cost the district many thousands more than the half-day program.

By 2003, rumors were beginning to swirl that Southtown Power was threatening to close Charlottesville, as the plant was not profitable. District officials ignored these rumors, as they had grown used to Charlottesville officials downplaying the profitability of the station for years. They believed that this was just another attempt to lower the property tax bill of the station.

In the spring of 2004, Southtown officially announced the closure of Charlottesville. District 208 officials quickly understood that two very large issues confronted them. 1. The county clerk would still schedule the building bond payments, but the district's homeowners would now pay a much larger portion of the bill. 2 . The district would quickly experience a $\$ 2$ million drop in revenue. Quick action would be needed.

The board decided to lengthen the term of the building bonds to a thirty-year term, effectively lengthening the payment schedule by seventeen years. By lengthening 
the term, the district also had to negotiate a higher interest rate on the building bonds. The community was outraged. More outrage ensued when district officials announced that several programs would be eliminated: all-day kindergarten, art, band, choir and all extra-curricular activities. In addition more classroom teachers would be cut in other grades and the class sizes would be rising.

The community began to attend board meetings by the tens and hundreds. Board members and administrators remember the stressful evenings that they experienced. Many tears were shed and the board was left with a feeling of helplessness. Some parents in the community quickly organized a group that approached the board to resurrect all the athletic programs. The board was hesitant to allow this to happen, but the community persisted. No formalized effort was ever made to save the other eliminated programs, and that was of large concern to the board. Nevertheless, the board relented and allowed sports to be brought back under the auspices of the parent booster club. The school district did not pay the coaches, but the district did maintain the playing fields and the district also kept an athletic director, who scheduled the events and hired the officials. By 2006, none of the other eliminated programs had been revived, but athletics remained.

In the Spring of 2005, the district placed a referendum issue on the ballot. This issue was asking the taxpayers to raise the tax rate in the education fund to offset the loss in revenue from Charlottesville's closing. The referendum was defeated by $65 \%$ to $35 \%$. District officials claimed that they ran the referendum even though they knew it would not pass. They felt that they needed to try to keep the positions that were being eliminated and this was their effort to do just that. 
After the defeat of the referendum, district officials continued to cut more teaching positions, and by the spring of 2006, an additional $\$ 1$ million had been cut from the education fund; however, the district was still operating an unbalanced budget.

\section{Emerging Themes}

An analysis of underlying patterns has provided evidence to suggest several emerging themes relevant to Tigertown Elementary School District 208.

\section{Theme \#1 Tenuous Relationship with the Community}

The Tigertown community had not placed a great amount of faith in District 208

for years. Board member Carrie alluded to an underlying theme of historical community distrust:

I moved to Tigertown in 1989 and before I even had kids in the school my babysitter told me that the school board wasn't very trustworthy and people tended to suspect anything the board said. People seemed to ignore the fact that it was a total different board. Every two years, new members come on and still the board couldn't shake this reputation that we couldn't be trusted. People just seemed to want to assume the worst about us.

This distrust could very well have come from the fact that the school district had gotten into the habit of using debt in the form of working cash to operate its daily activities.

It was widely reported in this chapter that District 208 officials had, for years, attempted separate referenda in an effort to halt the district's practice of using working cash bonds to partially fund the district's regular programs. All of these referenda failed. When the district needed the community's support for a new building, though, a largescale effort was made to include community members in the process of planning and running a referendum to build and renovate these buildings. When the community was involved, they seemed to respond. When district officials failed to live up to their promises, though, the community took notice. The board had promised, for years, that if 
the district could only bring in more money, they could halt their practice of using working cash bonds to partially fund programs.

In 2000, Charlottesville was sold and a great deal of money flooded into the district's coffers. Instead of living up to their promises, the district went in the exact opposite direction. Rather than live within its means, the district took on even more expense to add all-day kindergarten.

\section{Theme \#2 Ignoring the Warning Signs}

Fast forward to 2003, officials from Charlottesville began to claim that they were having difficulty keeping the station profitable. Superintendent King attended meetings with other taxing body representatives. These meetings were held at the behest of Southtown Power. The plant officials were attempting to show these taxing body leaders that the plant was having financial difficulties. Superintendent King and the members of the board assumed that these meetings were only being held to aid in Southtown's efforts to reduce their tax bill.

Scott King said very assertively that he really had no idea that Charlottesville Station was going to close. None of the board members in District 208 indicated that they had any strong inclination of its impending demise, either. But Superintendent King did say, at one point, that he knew it was a possibility. Why, then, did he choose to ignore that possibility? Why didn't he educate the board that if Charlottesville closed, the District could not sustain the programs they had in place? After the closure was announced, administrators were forced to quickly put together scenarios that the board could use when deciding what programs would need to go and what programs would be allowed to remain. These scenarios could have been created in 2003, when rumors were 
swirling that Southtown was unhappy with the profitability of Charlottesville Station, yet nothing was done.

The community voiced its displeasure to the board and administration that they should have known that the plant was going to close. Both district's boards and administrators spoke of that type of accusation. But the high school administration took a much more proactive stance, in the fact that they began to create scenarios that used the assumption of no EAV from Charlottesville. At District 208, no communication to the board took place, and no scenarios were created.

As has been stated previously, it is quite possible that District 208 administrators had grown all-too comfortable with the rumors that had been swirling. Remember, officials from Charlottesville always protested the value of the station and district officials were forced, on a yearly basis, to hire outside counsel to challenge Charlottesville at the county level (to the Haynes County Assessment Board). This type of reaction is almost identical to the behavior to which March refers when he theorizes that those that make decisions are too often biased by past events...but only those past events that actually happened, and not by any of the events that could have happened if certain variables had been altered.

It's impossible to know what might have happened if District 208 officials had begun making plans prior to the announced closure of Charlottesville Station. Perhaps, different decisions would have been made. Perhaps, the district could have held meeting with the public informing them of what might happen to their tax bills if Charlottesville closed. Then, when the closure occurred, people might not have been as upset. 
Similar to the findings regarding the high school district, it is helpful to review the work of Argyris in this case, as well. Decision-makers tend to avoid situations that might cause embarrassment or stress. Typically, important issues are ignored rather than confronted, lest people discover what is actually going on in the organization. Superintendent King said that he had no idea that the plant was going to close, but it's possible that he simply did not wish to confront the issue, so he put it out of his mind. The board seemed sufficiently shocked, as well. It is likely that they did not wish to confront this reality, especially in light of the stress that it eventually caused when the rumors turned out to be true.

\section{Theme \#3 The Duplicitous Face of the School District}

When officials from Southtown Power announced that the Charlottesville Station would close in the spring of 2005, District 208 officials had to act quickly. They needed to make deep cuts in their programs and they needed to find a way to keep the tax rate low enough that people would not be taxed out of their homes. Remember, the bond payments for the building construction and renovation would still need to be met, and it was now up to the remaining taxpayers to make up for the loss of Charlottesville's obligation. This caused the board to lengthen the bond payment schedule so that the yearly obligation would be reduced, but the overall payment would grow. District officials also decided that they should run one more referendum in an attempt to avoid making the cuts due to the loss of property tax revenue from Charlottesville.

Argyris asserts that management typically looks for ways to avoid discomfort or stress. It is very important for organizations to "save face" in the eyes of its external and 
internal publics. In the case of District 208, the board attempted to give one message to the staff, but give a different message to the community.

Over the course of the past two decades, the district had attempted separate referenda in the hopes of increasing the amount of money brought into the education fund on a yearly basis. The board of education attempted to explain to the community that an influx of money would allow the board to stop its practice of borrowing from the working cash fund to support the education fund. Each attempt failed. The community had repeatedly sent the message to the board that they did not wish to raise their taxes. The only exception came in the late 1990's when the voters approved a building bond referendum to construct Centerville School and to renovate Laird Middle School. When an opportunity arose for the district to use a large influx of tax dollars to stop borrowing, the board went in entirely the opposite direction and expanded programs.

Only four short years later, the board was forced to reverse course and cut the allday kindergarten program they had just created. In addition, they were forced to cut other programs in an attempt to keep the district financially viable. The community was outraged at the fact that the homeowners' tax rates would rise so dramatically, and because so many opportunities for children would be eliminated from the school's daily programs. An outside group of businesspeople even came to the central office and examined the district's financial records because these businesspeople didn't have trust in the administration or board.

At the same time that drastic cuts were being made so that the school could be financially responsible to the public, the school district ran a referendum so they could show the staff that they were trying to keep everyone employed in their same positions. 
Put simply, the board and administration were doing what Argyris claims most decisionmakers do...attempt to avoid unpleasant situations.

When speaking to the public, the district officials made the case that they were trying to be responsible managers of taxpayer dollars. When speaking to the staff, these same people made the case that they would do whatever they could to find more money so that they could keep the teachers that would otherwise be cut due to the lack of revenue from Charlottesville Station. When looking through this lens, it becomes clearer to see why the community did not have a great amount of faith in the school district to properly manage the district's finances.

\section{Theme \#4 Community not Supportive of Education}

Similar to District 39, officials in District 208 complained that the community was not supportive of education. The actions described above could lead a person to the same conclusion. First, the community had voted eight different referenda down. The only referendum that had passed in the previous twenty years had been the referendum that called for the construction of Centerville and the addition onto Laird Middle School. District officials, for years, had attempted to explain to the community that their practice of borrowing could be eliminated if the education fund could bring in more money. But, as was argued above, it is possible that the community had grown weary of the district's promises, as they did not live up to them when a great deal of money flooded into the education fund in 2001 (via the sale of Charlottesville in 2000).

When you look at what programs were revived, though, you begin to see why district officials felt, and feel, the way they do. The community only organized an effort to save athletics. Different concerned community members brought up band, choir, art 
and all-day kindergarten, but no organized effort was ever given to save them. It took a great deal of effort, money and organization to revive the sports programs, and all of it was done between April 2005 and August 2005. This type of organization is impressive, but it goes to show that the community will rally behind what it loves most, sports.

At Tigertown High School, no cuts were even made in athletics... at least at District 208, district officials made those programs among the first to be eliminated. But when the community pushed back, the board relented and allowed those programs to be revived. Previously, it was mentioned that the district attempted to absolve itself from any financial responsibility associated with athletics, but they never eliminated the athletic director position. They also paid for the utilities in the buildings when athletic events were held. They also paid for the athletic fields to be maintained. While these costs are not as substantial as completely operating a vibrant set of athletic programs, it is also not free. The district ultimately supported one set of extra-curricular activities, while they allowed all activities in the arts to go by the wayside. It is commendable that one building principal put on two musical performances at Centerville School. It is also commendable that the district found a way to keep band alive in a very minimal way. But the costs associated with band and choir were not as substantial as the costs that were incurred for athletics. It appears that the District supported what the community valued.

The community's support for athletics almost certainly played a hand in the resurrection of the sports programs. It is evident that the community valued sports because they organized an effort to keep the programs. It is also evident that the board wished to do something positive, and reviving the sports programs seemed to be the easiest method of doing just that. But when the board members all expressed a large 
amount of concern over the fact that only sports was brought back, yet they did nothing to reverse that course, it says something about the board's decision-making, as well. In the end, when the community threw its collective weight behind athletics and nothing else, athletics was saved. The arts were all but eliminated from the school system, and the board members mentioned that they valued those programs as well. The problem is nobody confronted the board with an organized effort to save the arts, so nothing was done.

When considering the research question, (How did the District deal with the closure of Charlottesville?) it can be summarized fairly simply. The board felt that the bond payments for the building construction and renovation would need to be lengthened in order to avoid taxing people out of their homes. Even though the board knew that this decision would be roundly criticized, they felt a moral obligation to make that decision.

In addition, the board sought the counsel of the superintendent and business manager. These administrators created different scenarios through which the board could better understand the impact of the cuts that would need to be made. The board gave the administration its priories of keeping class sizes as small as possible, and to keep the core curriculum intact. Since no planning was done prior to the announced closure, these decisions were made quickly. Instead of trimming back programs, entire programs were eliminated. The all-day kindergarten program that had only been created a few years prior was among the first programs to be recommended for elimination. All band, choir, art and extra-curricular programs were recommended for complete elimination, as well.

When the board announced the planned cuts, an organized parent group approached the board in an effort to save the extra-curricular programs. The board 
members expressed strong reservations regarding the support of the parents' plan. In the end, though, the board allowed the extra-curricular programs to be re-established, but the board said that they would not fund any of these programs and it would be the parent group's obligation to find a way to pay for the coaches, uniforms, travel, etc. The board did ultimately keep an athletic director, and they agreed to maintain the athletic facilities. No board member was happy with this decision, but they felt that they needed to allow the parent group's request because they wouldn't have to eliminate those opportunities for students.

An attempt was made at raising the tax rate in the education fund via referendum, but that question failed by a wide margin and the board was forced to continue cutting the following year. 


\section{CHAPTER VI}

\section{CONCLUSIONS, DISCUSSION, IMPLICATIONS,}

\section{AND RECOMMENDATIONS}

Chapter VI serves as a general overview of this entire research project. It commences with a restatement of the research problem and briefly describes the research design. Next, this chapter summarizes the findings and presents the researcher's conclusions to the research question that directed the study. Also these findings will be compared to the current educational literature on the subject. Finally, this chapter will convey the implications of this research project for educational practitioners and researchers and for those faced with the challenge of financial retrenchment that must be implemented over a short period of time.

\section{Overview of the Study}

\section{Statement of the Problem}

Although there is great concern about the adequacy of funding for schools, few researchers have examined how school district administrators manage the fiscal retrenchment made necessary by budget reductions. The research that does exist is dated and examines the impact of relatively small reductions in revenue streams over time and does not provide insight into how districts cope with significant budget cuts that result from a change in the mix of revenue sources on which they are dependent.

\section{Design of the Study}

This study was designed to investigate the processes used in determining what budgetary cuts were to be made in two school districts (one elementary and one high 
school) that served the same community. These cuts were made necessary by the closing of an electric generating facility that was part of both school districts' tax rolls.

The districts under study were chosen for two reasons: (1) They were both affected by the closure of the power plant, and (2) They exemplify the peculiar nature of Illinois public schools. Even though both districts exist in the same relatively small town and serve the same families throughout their schooling, they remain separate entities. In the majority of states, individual school districts are responsible for all educational levels Pre-Kindergarten through $12^{\text {th }}$ grade (these types of districts are know as "unit districts"). In Illinois there are regional proliferations of "dual districts": one district is responsible for Pre-Kindergarten through $8^{\text {th }}$ grade (elementary districts) and a separate district is responsible for $9^{\text {th }}$ grade through $12^{\text {th }}$ grade (high school districts). This particular community will offer parallel experiences of two school districts that serve the same community, yet they are separate and distinct entities that are responsible for different levels of public education.

The two districts under study are parallel in that the power plant that closed was responsible for over $45 \%$ of the property tax revenue collected by each district. The two districts are also parallel because a family that has a child in the $5^{\text {th }}$ grade and the $9^{\text {th }}$ grade would have two children in two different school districts. That family pays property taxes to two different school districts that are overseen by two different school boards and superintendents. These separate school boards and superintendents reacted in a similar, but not identical, fashion.

The flexibility inherent in case study design allowed for a semi-structured interview format that used a list of questions or issues to be explored. The format 
allowed for follow-up questions to be asked, depending on the individual responses of the interviewees. This semi-structured interview format provided the researcher the opportunity to explore the different experiences that each interviewee had, in order to gain a more accurate representation of their ideas and feelings with regards to their experiences associated with the retrenchment process as a result of the closing of the power plant.

District Reactions to the Loss of Revenue

Tigertown High School District 39

Prior to the sale of Charlottesville in 2000, the high school had grown accustomed to using working cash bonds to supplement the district's yearly shortfall in the education fund. In essence, the district was using debt to operate its programs. After the sale of the plant, the school board, at the direction of the superintendent, began to use the excess dollars that flowed into the education fund (as the result of the increased EAV) to halt that practice. At the same time, the district began a remodeling project for the building.

Once the superintendent began hearing rumors that the plant may close, he began to lay out plans for what the district may need to do if the plant did, indeed close. This planning began a full year prior to the announced closure. While the superintendent did not communicate this activity to the board of education, he did work in earnest so that the district would be prepared.

When the officials from Southtown Power announced in 2004 that the plant would close in 2005, the superintendent revealed his plans to the board. Since the district had already stopped borrowing money and had created a small reserve, the cuts did not have to go very deep. No programs were eliminated, but some positions that were left 
vacant by retirements were not filled. Two teachers were released, and students had to pay a usage fee in order to participate in after school activities and to attend the area's vocational center. The district did have to issue tax anticipation warrants, but the superintendent created a long-term plan to eventually stop that practice.

At the same time that all of these financial issues occurred, a separate issue was taking a large part of the board and administration's time. A long-standing coach in the district was nearing retirement. Three years prior to his retirement, he had signed an irrevocable letter of resignation in return for three consecutive large annual raises. This coach had been a powerful and influential person in the school and community for over two decades. In the end, he did not wish to relinquish his role as athletic director, as he had contractually agreed to do. A large segment of the community rallied behind the coach. The board held a special meeting in the high school gymnasium to give the public an opportunity to address the board regarding their disdain for the fact that the coach would no longer be allowed to be athletic director. The board reiterated its stance that the coach could remain the head football coach, but that he would have to relinquish his role as athletic director, per the contractual agreement signed three years prior. In anger, the coach resigned his position as football coach, as well. It appears that the board achieved what Culbertson (1977) stated was possible: Opportunity for change arises when financial retrenchment practices are initiated. It is typical for school leaders to avoid making unpleasant decisions (as Argyris attests), but when the status quo must be questioned as a result of financial needs, the opportunity arises to make desired changes. The financial situation can be used as an excuse for making these changes, which is precisely what the district officials did in this case. 
There were themes that emerged during the course of studying Tigertown High School District 39 that could help explain why the district behaved the way it did during the retrenchment process.

First, there had been a quiet power struggle taking place for a few years prior to the close of Charlottesville. Coach K. had managed to control several different boards of education and superintendents, but this board and superintendent did not allow that to happen. As a result, the coach began sowing seeds of discontent within the community and also within the school. There was a faction of the faculty that did not trust the administration and board. The district leaders were trying to change the culture of the school to allow for more collegiality and these leaders felt that as long as Coach K. were still around, their efforts would be thwarted.

Second, the superintendent and board of education had a very strong relationship. So strong, in fact, that the board relied very heavily on the superintendent to make almost all of the decisions for the district. When Wilbur Johnson first began making plans for the potential closure of Charlottesville, he did not inform the board. Later, when he quickly produced plans for cutting expenditures, the board only expressed gratitude for his work. He was never questioned as to how long he had had these plans, nor was he questioned as to why he never informed the board of his fears.

Third, the plant closure acted as an accelerant in regard to the animosity between Coach K. and the administration and board of education. For far too long, Coach K. was given whatever he wanted. He was allowed to bully and intimidate others in order to further his own agenda. The superintendent and board at the time of the plant closure no longer wished to allow the coach to behave this way. The drop in revenue forced the 
district to look at all programs to see what cuts should be made. The board attempted to work with the teachers, but they did not want any part of the discussions. The teachers' response is not surprising when you consider 1 . The teachers were in the middle of a collective bargaining agreement and did not wish to forfeit their contractual raises; and 2. The teachers did not wish to step in the middle of a fight between the coach and the board and administration.

The board and administration were ultimately able to use the district's financial problems as a means of removing the coach/athletic director via retirement. The board was even more fortunate when the coach, in a fit of rage, turned in his resignation as football coach, even though the board had told him he could keep that job.

Finally, the community, in general, was not supportive of education. This was evidenced by the small turnout at board meetings and the small turnout when the district held an open house for the renovated building. It was also evidenced by the community's voiced concern over what programs were in danger of being cut. Each board member stated that sports were the focus of the community during that time, not academics.

When the board held a special meeting to discuss Coach K's situation, there were hundreds of people in attendance. When the board held public meetings to discuss the ramifications of the plant closure, there were fewer than ten community members in attendance.

In addition, the school board did not place a large focus on academics during the retrenchment process. According to the board president, a small survey was given to a few high school students to help the board determine how effective the academic programs were for the students. No large-scale study was done. There was no 
examination of the district's mission, no cost/benefit analysis of district programs to determine their effectiveness. In the end, the board truly didn't retrench. They simply trimmed around the edges of the current academic system in place. According to Culbertson (1977), retrenchment offers an organization with an opportunity. An opportunity to re-examine district priorities and re-focus the efforts of the whole. It appears that the only opportunity taken in this case was the opportunity to rid the district of Coach K. While this effort is laudable, it is disappointing that no more was done. In the end, the students were not deeply affected by the closure... and that can be seen as a positive or a negative.

\section{Elementary District 208}

In 1998, the district ran a referendum to close three elementary buildings and build a new PK-5 structure. That referendum also called for an addition to be built onto the existing middle school. That successful referendum raised the tax rate at the time by sixty cents.

In 2000, when Charlottesville Station was sold, the district did not halt its practice of using working cash bonds to operate its daily programs, as the high school had done. Instead, they expanded programs, including adding all-day kindergarten.

In 2003, when rumors began to swirl that Charlottesville may close, the superintendent and board ignored those warnings, as they had grown accustomed to hearing them each year at the county assessment board hearings, when Charlottesville officials would protest the taxable value of the station. The superintendent and business manager did not put together any scenarios that would plan for what expenses would be cut in the event of a plant closure. 
When the announced closure came in 2004, district officials were stunned. Not only would they have to quickly line out plans for budget cuts, they felt they also needed to refinance the bonds that were paying for the construction of Centerville School and the addition onto Laird Middle School. The bonds were refinanced at a higher rate over a longer period of time.

In addition, all athletic, art, band and choir programs were eliminated. When the community pushed back on the athletics issue, the board relented and allowed a parent group to operate the athletic programs. This coincides with the work of Bellon (1977) who states that districts need to achieve unity of purpose prior to making any long-lasting decisions. District 208 leaders failed to achieve unity of purpose; therefore, when an organized group of parents challenged the board's decisions, the board acquiesced to the group's appeals, even though the board members expressed strong reservations about their decision. Some efforts were made to maintain some offerings in band, but those were outside of school and were not as organized, nor as comprehensive as athletics.

There were themes that emerged during the course of studying Tigertown Elementary School District 208 that could help explain why the district behaved the way it did during the retrenchment process.

First, the relationship between the school district and community had been tenuous for years. One board member was quoted as saying that she was told in the late 1980's (when she first moved to the district) that the board could not be trusted. Even though all of the board members had changed since that comment had been made, the belief remained. The community was concerned that money was being wasted at the school. The district was not doing anything to help itself by continuing its practice of 
using working cash fund bonds to partially fund the education fund. This practice had been going on for years, and several boards of education had attempted to pass referenda to allow for an influx of money to the education fund for the express purpose of halting the practice. When the money did flow in, though, not via referendum but via the spike in value of the Charlottesville Station, the board did not halt the practice of borrowing and, instead, expanded district programs.

Second, district officials were warned of the potential of the closure of Charlottesville in 2003, but they ignored those warnings. This resulted in the district being unprepared for the choices it would have to make only one year later. In 2004, Charlottesville's closure was announced and district officials were stunned. The high school district had made plans for this event, but the elementary district had not. What made matters even worse was that the bond payments for the new school would still need to be made without the help of tax money from Charlottesville. Many decisions needed to be made in a very short period of time.

Third, the district sent one message to the public and a different message to the internal public (faculty and staff). At its meetings, the board would state to the public that they were doing all they could to be good stewards of the taxpayers' money. They knew they were going to have to cut costs and those cuts would be made in order to keep the district financially viable in the future. To the teachers (at faculty meetings) the message was that great effort would be made to keep all employees. A referendum would be run so that jobs could be saved. It is very difficult to make everyone happy, especially in times of financial retrenchment; however, a school district should still never attempt to send one consistent message to one group of people and send a consistently 
contradictory message to another group of people. It is actions like these that make it more understandable as to why the district had had a credibility problem for decades.

Finally, the community demonstrated a great deal of concern for cuts to extracurricular programs. There was so much consternation, in fact, that an organized effort was made to privately fund and operate these programs. The school board ultimately allowed this parent booster club to run all athletic programs, even though they stated that they were not sure it was a good idea.

No such effort was made for the arts or for any other district program. Put simply, the community demonstrated that it was more concerned about athletics than it was academics. The board members said that they felt pressure to bring back sports more than any other program.

It is unfortunate that the board did not achieve a unity of purpose during its retrenchment process. If it had, the distraction of the parent group could have been greatly mitigated or even eliminated. Similar to the high school, no program analysis was done. Cuts were not made via a consideration for the district's mission. Instead, each board member said that the academic core must be maintained. No one ever specifically stated what the academic core was, but it can be assumed that reading, writing, math, science, physical education and social studies were saved, as those are specifically state mandated pieces of any district's curriculum.

\section{Summary of Findings}

Considering the studies of both districts in totality, a number of themes emerged from this study: 
(1) The administrators and the boards of education exhibited a desire to avoid conflict;

(2) Community support for the educational mission of the district (as opposed to peripheral, athletic programming) was not forthcoming;

(3) The leadership of both districts failed to keep the community informed of the schools' academic goals and purpose.

All three suggest the displacement of academic considerations as the main driver of the districts' responses to the revenue shortfall caused by the closure of the power plant.

\section{$\underline{\text { Key Leaders Avoid Conflict }}$}

Argyris (1992) states that, in general, people within organizations, attempt to control embarrassment or threat when making decisions. The elementary district leadership attempted to communicate one plan of action to the taxpayers and another plan of action to the employees of the district. It was repeatedly mentioned in the study that the elementary district had an image problem in the community. It is quite possible that this image problem grew out of the district's unreliability (which was displayed in the district's duplicitous behavior). In addition, when confronted by a group of parents who wished to see athletics return, the board attempted to appease them by doing what they expressly opposed (reviving sports without reviving any other programs). These behaviors do not indicate a rational plan of action, which was sorely needed at that time, but rather a desire to avoid conflict and community anger. When considering this driver, it becomes easier to understand why the district ran a referendum after the plant closed the district was looking for a way to avoid the stress of making deep program cuts. The failed referendum attempt also gave the board and administration an opportunity to place 
some of the blame for cuts on the community, rather than forcing themselves to look back at their actions of borrowing to run regular programs.

In addition, the high school district leadership was facing an angry group of teachers, due to the ongoing battles with Coach K. Many of their problems emanated from actions of previous boards of education and administrators, who did whatever they could to avoid conflict with the Coach. According to Berman and McLaughlin (1978), schools are a combination of many different interest groups who co-exist peacefully as long as no group is individually threatened by change. When the high school leadership finally decided to take on Coach K. this peaceful co-existence was disrupted. The board and administration were able to use the district's financial situation as a means of explaining their actions in their dealings with the coach. They never outwardly stated that they wanted to see the coach leave, rather they publically stated that they needed to save money, and if Coach K. were allowed to stay, they would have to spend beyond their means. While some money was, indeed saved, the greater desire of the board was obfuscated from the community in order to avoid any more conflict.

\section{Community Support for Academics Not Forthcoming}

Much of the strategy employed by both districts to avoid conflict was related to the fact that the community was not supportive of education. The community of Tigertown is deeply proud of its athletic accomplishments. Football is a way of life in the community. The downtown businesses alter their hours of operation on Friday nights in the fall. The taverns and restaurants are always crowded before and after games. To say athletics and particularly football are important in Tigertown would be an 
understatement. Each district was forced to cut costs, but in the end, athletics were left largely unaffected by the cuts.

In the elementary district, an organized effort was made to save athletics but not to save band and choir and art. Class sizes were raised and all-day kindergarten was eliminated. But it was sports that caused the most emotive responses among the parents. It was sports that were financially supported and it was sports that were lobbied to be saved. The board members all expressed concern about reviving athletics, but, in the end, they acquiesced to the community's wishes and the residents of Tigertown got what they wanted. Since there seemed to be no coordinated effort by the board to save any one particular program, it can be assumed that if a large group of parents had lobbied just as hard for band and had offered to pay for it, the board would have revived that program instead of sports. But no such effort was made and band was not revived.

At the high school, more time was given to deal with the issue of Coach K. than was given to deal with the financial problems facing the district. Very few people ever showed up for regular board meetings and only twelve people showed up for the building open house. But when the board held a special meeting to discuss the issue of Coach K's retirement, the meeting had to be moved to the high school gymnasium. The community spoke with their sheer presence. On issues of academic importance, there was little to no community involvement. On issues dealing directly with athletics, the community showed up in droves. This forced the board to spend a great deal of time away from its central mission of improving and supporting the academic goals of the high school. Since so much time had to be devoted to the Coach K. issue, the board relied very heavily on the superintendent to handle the financial issues that were facing the district. Also, 
since so much time had to be devoted to Coach K., the board did not either have the time, or failed to take the time, to perform a full-scale study of its academic offerings and the cost of each of those programs.

When you consider that the community, through its actions, demonstrated a far greater concern for athletics than academics, the board's time devoted to athletic issues more than likely seemed appropriate. When you consider the board's purpose of supporting academics, though, the board's time seems to have been wasted on peripheral issues. Since time is not renewable, that precious resource was wasted in the months following the closure of Charlottesville. Those that were interviewed conveyed a general feeling of frustration over the fact that the board had to deal with distractions far too often, when more time should have been devoted to dealing with the financial issues facing the schools. These distractions, though, were allowed to continue because both boards failed to focus the community and themselves on the central issue at hand...financially retrenching each school district. This inability to focus is the final driver to be reviewed.

\section{Leadership Fails to Keep the Community Focused on Academics}

According to Culbertson (1977), in times of financial retrenchment, organizations can be given a unity of purpose and strong leaders can capitalize on this unity of purpose and translate it to the community-at-large and lead them towards a desired end. Neither district in this study exhibited any understanding of a core mission. Both districts were forced to deal with many different distractions, and many of those distractions were allowed to enter into the collective discussions because there was no focus aimed at fulfilling the mission of the school district with less money. 
Both districts had limited capacities to deal with the retrenchment process because the district leaders didn't shepherd the board through this period with a tangible goal toward which to work. Instead, the high school administration and board simply took small steps to eliminate positions via attrition or they hired inexpensive young teachers to replace more costly veteran teachers that were retiring. No concerted effort was made to determine if the current educational system was the desired system, or if it could be maintained going forward. The elementary district was searching for ways to remain financially solvent, not for ways to further the educational mission of the district via the retrenchment process. As a result, the board acquiesced to the community sports boosters because they didn't have to spend district money to resurrect the program. The issue became more about money than about academics.

In addition, communication from the district leadership to their respective boards was lacking. The high school superintendent had the foresight to begin making plans for the closure of Charlottesville a year prior to its actual occurrence; however, he never communicated these plans to the board. This left the board largely unprepared for what to do after the plant closed. The effect of these inactions was that the high school board of education was almost completely dependent upon the superintendent during the retrenchment process. He possessed the knowledge they needed at that time, so they left almost all the work to him, rather than acting as an overseer of the process.

The elementary district superintendent attended meetings where it was warned that Charlottesville Station was not profitable and may close. He never communicated this message to his board of education, as he assumed the message was a ploy from the power company to lower its assessed value. Similar to the high school, when the plant 
closed, the board was left with little time to plan for cuts. Hasty decisions were made out of necessity and the desire for expediency, rather than focusing those decisions on the academic aims of the district.

Administrative Implications

The experiences of these two districts suggest several implications for administrators whose districts might face a significant revenue shortfall.

\section{Focus the Community on Academic Goals}

When a board of education is forced to cut expenses, it is important to publically state the district's priorities and attempt to achieve a unity of purpose when attempting to financially retrench a school district. As stated above in the previous section, both districts were forced to deal with many distractions that could have been avoided if more work had been done to focus the community's attention on attaining financial and academic goals. Each school district's mission statement would be a proper tool to use when determining what cuts should be made. A continuous process of program evaluation should be undertaken to determine the effectiveness of all district programs. If these programs still further the mission, then they should be kept. If they do not further the mission, they should be changed or eliminated.

In times of retrenchment, difficult decisions will need to be made regarding the future of many district programs. If district leaders have done their part to keep the district mission at the forefront of the stakeholders' collective conscience, more meaningful discussion and analysis can be undertaken. There will be fewer distractions, and the district can move forward with less harm to students. The decisions that get made will more than likely be decisions that are based more on fact and less on emotion. 
While commenting on the political nature of schools, Zerchykov (1982) claimed that schools are best seen as "polities" - coalitions of internal and external interest groups - whose decision-making procedures more closely mirror a process of interest group bargaining rather than objective fact-finding. This assertion was found to exist, in at least a limited sense, in both the high school and elementary school districts. The high school was forced to deal with a teacher/coach who had created a strong power base within the community. When that teacher and the administration began to disagree, the community got involved and the problem became less manageable. In the case of the elementary district, an organized group of parents organized to lobby the district to resurrect the athletic programs. It was found that the board struggled with the decision of whether or not to allow this booster club to run these programs. In the end, the board relented and the athletics were, in effect, never cut.

When a community group places pressure on the board to commit resources toward a particular program or set of programs, that public desire must be compared with what the district has declared is important. In the absence of a public declaration, it can be assumed by the public that changes can be made to any plan, as long as enough pressure is placed on the board. The district is then placing itself in a precarious situation where it is attempting to please everybody without a plan for addressing any issues. When priorities and missions are publically stated, those priorities can form the bedrock of whatever changes have to be made. While the community may not agree with what the board has to say, the board can at least show that it is operating under a planned course of action, and anything that is suggested that goes against that plan, will not be considered at that time. 


\section{Communication}

More communication is needed between the central office, specifically the superintendent, and the board of education. While it is virtually impossible for a superintendent to let the board know everything he or she knows, it is highly advisable to inform the board on matters of critical interest. When the plant was rumored to close, neither superintendent voiced any concern to either board. Had the superintendents informed their boards of the potential closing, plans may have been altered and greater thought could have been put into the planning that was eventually forced to be done in a very short time span. Also, the board of education is the public voice for the school district. Had board members known that the plant might close, they could have voiced those concerns in the community. The community could have been better informed at the time and it is possible that each board, and particularly the elementary district's board, could have been spared some of the stress and anguish that occurred in the months after the announced closure.

Building upon that same theme, boards of education and administration need to establish a regular practice of communication with the internal and external publics, as well. Both boards expressed consternation over the fact that the community blamed them for not seeing into the future in regards to the closure of the power plant. Both boards expressed a desire in hindsight to do a better job of communicating each district's financial realities to the taxpayers. If a regular system of communication had been established, that information could have been in the minds of the community prior to the closure. When the plant closure was announced, the community might have better 
understood the financial calamity facing each district and it is possible that some of the pressure that was brought to bear might have been avoided.

In addition, the community may become more supportive of education, in general, if they were better informed of the educational offerings of both school districts.

Officials from both districts complained that the community did not value education, but neither district appeared to formulate a plan to change this culture. One portion of any plan would be to better inform the citizenry about the work that each district performs on a daily basis.

The only time a comprehensive communication plan was put into place over the course of this study was when the elementary district involved the community in its efforts to pass a building bond referendum. Perhaps, the elementary district could have learned from that successful referendum and used a similar process to run their subsequent failed referendum. This should provide a cautionary tale to all administrators and school boards. These decision-makers should create policies whereby community relations is a constant topic of conversation. The community should be involved on a regular basis, whether that be through school improvement teams, ad hoc finance committees, or other forums that the board deems acceptable and useful.

It is apparent in this study that the only time the community was truly involved was when the school districts wanted something from them. School boards and administration need to view the community as more than a means to an end. The board and administration need to take an active role in cultivating relationships with the external and internal publics so that knowledge can be more easily disseminated and regular input can be considered. The taxpayers don't understand school finance, unless it 
is explained to them. In the absence of information from the school, people will make their own assumptions.

\section{Greater Emphasis on Decision-Making vs. Conflict Avoidance}

Both districts displayed conflict avoidance behaviors. While these behaviors are certainly problematic, they are more a symptom than the cause. The deeper problem is the process by which decisions were made in both districts. In order to avoid the problems of both the high school and elementary school, a system of organizational learning should be created and fostered. This type of avoidance behavior could have been avoided if proper decision-making practices were enacted.

March (1994) attests that decision-makers tend to make decisions based on what has occurred in the past, with most or all of the emphasis placed on what actually happened in the past, rather than what could have happened. This same type of decisionmaking occurred in this study. Both sets of district officials said that they had grown accustomed to officials from the power plant protesting their taxes. Both sets of district officials said that when the complaining continued into 2003 and 2004, they didn't feel that anything would change. As a result, no action whatsoever was taken in the elementary district to plan for a potential closure. In the high school, the superintendent at least put together a plan for that possible conclusion, even if he didn't communicate that fact to the board. Quinn (1996) suggests that people believe that they can realistically predict what will happen based on what has happened in the past. He then refers to the process of "building the bridge as we walk on it" (p. 83), whereby decisionmakers realize that learning must take place all along any process of life, including times when decisions must be made. The decision-makers at the high school and elementary 
districts did not indicate that any type of organizational learning took place as retrenchment occurred. Instead, they complained that the teachers were upset, or the community was questioning the spending of the district. For any district that must approach this problem in the future, it would be best to heed the warnings of March and Quinn and begin the formalized process of organizational learning. The professional organizations that support these groups could formalize training in organizational learning. The superintendent can take on some or much of the responsibility in helping craft a board/superintendent relationship culture that is based on growth and learning.

Pfeffer and Selancik (2003) attest that environment determines how decisions are made and determines what decisions get made. "The idea was that if you wanted to understand organizational choices and actions, one place to begin this inquiry was to focus less on internal dynamics and the values and beliefs of leaders and more on the situations in which organizations were located and the pressures and constraints that emanated from those situations (p. xi)." In the dual cases of the high school district and the elementary school district, their environment in the years 2000-2006 was a turbulent one. First, the major source of revenue for both districts drastically increased in value. The high school chose one path and the elementary district chose another. When the power plant officials announced the closure, both districts were placed under extraordinary pressure, both internally and externally. Since the high school district had previously chosen a path of fiscal prudence, their path was far less bumpy.

The elementary district's tale is a cautionary one for all school districts across the country. Do not ever count on the past repeating itself. Assumptions were made and they were ultimately very costly ones, both for the taxpayers and for the children that 
attended the school district. In order for these school districts, or any school districts to move forward in a rational manner, a proper examination of the external world is crucial. It is also crucial to begin a process of community involvement and organizational learning and renewal. For the next problem may not be identical to the one brought forth in this study...but there will certainly be problems.

\section{An Aside for the Practitioner}

In addition, the experience of the two districts suggests that the practice of regular borrowing to support regular programs for a school district is ill advised. The occurrences that took place in these two districts show the stark difference between making a decision to create reserves and making a decision to continue borrowing. This is especially true in a district that is so resource dependent. Too many variables can come in to play when a large portion of your yearly revenue comes from one entity. This is not to say that borrowing does not have its place. There are times when borrowing is advisable, but typically it is only advisable when you are facing a one-time large capital project, such as building a new building or renovating an existing building. Think of it as you would your own personal finances. Typically, we borrow money to purchase homes or vehicles. It is generally not advisable to borrow money to pay your monthly bills, which is what both school districts had been doing for a long period of time. The high school district stopped this practice prior to the closing of Charlottesville, but the elementary district did not. When the regular revenue stream contracted, the elementary district had greater difficulty in their efforts to retrench the district.

Recommendations for Further Research 
It should be noted that this study was limited to two school districts located within the same community in Illinois. Furthermore, the information that was gathered by the researcher only covered the years of 2000 through 2006, with special emphasis placed only on 2004, when the plant's closure was announced. Consequently, it would be extremely difficult to generalize the findings of this research study across the country or even across the state. The study does provide meaningful anecdotal data that generates conclusions and suggests recommendations for further study. The results of this study support the need for further research in the field of retrenchment in the public arena. It has already been mentioned in previous chapters that no studies of public school retrenchment have been conducted since the 1970's. As was also previously stated, the current state of the economy will, no doubt, force other districts into a similar plight as the two districts in this study. Perhaps this study can serve as the groundwork for future research.

Future researchers could choose to replicate this study in school districts all over Illinois, or even across the country. While much of the financial data discussed here would be more particularistic to Illinois, the experiences and decision-making processes used in these two districts would inform others when they are looking for ways to make quick, long-lasting decisions for their schools. By expanding the research base, more generalizations could be made and the results could be more valid. As Merriam (1998) attests, a multi-site design allows the results to be applied to a greater range of situations. Another possibility for future study would be to focus on what state or national funding policies could be derived to help school districts overcome the economic hurdles that both of these districts faced. In the case of these districts, no such policy exists in 
Illinois to fill the short-term gap when EAVs fell and state aid had not caught up. Perhaps, another state's policies would account for this type of situation. A study that examines two cases in different states could illuminate the particular idiosyncrasies that exist in different state's models of public school funding.

March (1994) and Quinn (1996) have developed theories of how decision-makers deal with an unknown future. Perhaps additional studies could expand their research into how groups make quick decisions in the face of such a future. Board/Superintendent relations and the interconnectedness of these people in the process of making retrenchment decisions would be a useful study for all public bodies. It would be possible to focus on what occurs when the public is and isn't watching. Many decisions are made over the course of many months or years, but when these decisions must be made over the course of weeks, how do the Board/Superintendent dynamics change?

In addition, the work of Chris Argyris (1992) could be used as a lens in another study to try to understand the process by which administrators and boards create budgets, in general. The study that was conducted here focused on how budgets were cut in a short amount of time. A similar study could be conducted to see how the budget was built. It would further the educational knowledge of how building and district budgets are constructed and implemented. A budget is a reflection of the values of the organization. A researcher could examine those stated values of a district and compare the stated values with the proportion of dollars that are directed toward fulfilling the district's stated aims.

Finally, an additional study could be made of these same two districts to see what has transpired since 2006. There are new administrators and new board members in both 
districts. It would be illuminating to see more of the long-term implications of the decisions that were made in 2000, 2004 and beyond. That study could focus on political climate and how these quickly made decisions affect the long-term culture of school districts.

These studies suggest only a small sampling of additional research in the area of public school retrenchment, in general, and the need for a compressed decision-making process in these particular districts. The greater issue of public school finance has been widely researched across the country and even within Illinois; however, the particular problems that these districts faced are not only endemic to these two districts, or even to Illinois. Schools all across the country are facing a difficult financial future as a result of the downturn in the economy. Decision-makers are now being forced to chart a course into unknown territory. The more informed the decision-makers could be as to how to deal with an uncertain future, the better. School systems will still be asked to teach children, whether it is with more money or less. Proper planning should continue to take place, no matter the situation. 


\section{Bibliography}

Argyris, C. (1992). On Organizational Learning. Malden, MA: Blackwell Publishers.

Bacharach, S.B., \& Lawlor, E.J. (1980). Power and politics in organizations.

San Francisco: Jossey-Bass.

Bellon, J.J. (1977). Strengthening the educational program in a period of decline.

Declining enrollments and school closings. J.D. Bailey, Ed. Topeka, KS:

University of Kansas, School of Education. 143(099), 12-16.

Berman, P., \& McLaughlin, M.W. (1978). The management of decline: Problems, opportunities, and research questions. The Rand Paper Series: P-5984.

Bolman, L.G., \& Deal, T.E. (1997). Reframing organizations: Artistry, choice, and leadership (2 ${ }^{\text {nd }}$ ed.). San Francisco: Jossey-Bass.

Boyd, W.L. (1979). Education policymaking in declining suburban school districts: Some preliminary findings. Education and Urban Society. 5, 333-366

Boyd, W.L. (1982). Retrenchment in American education: The politics of efficiency. California Journal of Teacher Education: 9(11), 67-78.

Boyne, G. (2006). Strategies for Public Service Turnaround: Lessons From the Private Sector?. Administration and Society. 38:3. July 2006, pp. 365-388.

City Data, (2008). Retrieved February 2, 2009, from http://www.city-data.com.

Clark, B.R. (1975). The organizational saga in higher education. In J.V. Baldridge \& T.E. Deal (Eds.), Managing change in educational organizations. Berkeley, CA: McCutchan Books.

Cresswell, J.W. (2003). Research design: Qualitative, quantitative, and mixed methods approaches $\left(2^{\text {nd }}\right.$ ed.). Thousand Oaks, CA: Sage Publications. 
Cuban, L. (1979). Shrinking enrollments and consolidation: Political and Organizational impacts in Arlington, Virginia 1973-1978. Education and Urban Society. 5, 367395.

Culbertson, J. (1977). Educational leadership: The uses of adversity. Declining enrollments and school closings: 143(099), 39-49.

Dawson, L. (2001). Feeling the impact of tax caps. Illinois School Board Journal. Retrieved June 2, 2006, from http://www.iasb.com/files/j1010205.htm.

Dembowski, F. (1979). The effects of declining enrollments on instructional programs and supervisory practices in public elementary and secondary schools. Alexandria, VA: Association of School Business Officials International.

Education Funding Advisory Board. (2002). General state aid recommendations: An interim report submitted to the Illinois General Assembly. Springfield, IL: R. Leininger, Chair.

Eisenberger, K.E. (1977). Ways of meeting decline. Declining enrollments and school closings: 143(099), 34-38.

Freeman, J., \& Hannan, M.T. (1975). Growth and decline process in organizations. American Sociological Review: 40(2), 215-227.

Freeman, J., \& Hannan, M.T. (1981). Effects of resources and enrollments on growth and decline in school districts: Evidence from California and New York. Palo Alto, CA: Institute for Research on Educational Finance and Governance, Stanford University.

Hambrick, D. (1985). Turnaround Strategies. In W. Guth (ed.), Handbook of business strategy (pp. 3-32). Boston: Warren, Gorham and Lamont. 
Illinois Association of School Boards. (2002). Twelve questions and answers:

Understanding school finance. Springfield, IL: M. Johnson, Executive Director.

Illinois Association of School Boards. (2004). 2004 Illinois school code. Charlottesville, VA: Matthew Bender \& Company.

Illinois Local Education Agency Retrieval Network. (2009). Retrived February 2, 2009, from http://weprod1.isbe.net/ilearn.

Illinois School Code. (2008) Matthew Bender and Company, Inc (Ed). Lexis Nexis. Charlottesville, VA.

Illinois State Board of Education. (1999). State, local and federal financing for Illinois public schools. Springfield, IL: D. Weidler, N. Spinner, \& F. Hanselman.

Illinois State Board of Education. (2008). Illinois school districts showing improved financial health. Retrieved February 6, 2009, from http://www.isbe.net.

Kelly, J. (2002). Shutter the hometown school? The hardest animal to kill in Illinois is a school mascot. Illinois Issues Online. Retrieved June 2, 2006, from http://illinoisissues.uis.edu/features/2002mar/school.html.

Keough, William, taken from Abramowitz, Susan, Ed. \& Rosenfeld, Stuart, Ed., (1978). Enrollment decline: The dilemma from the superintendent's chair. Declining enrollment: Challenge of the coming decade, 331-370.

Kvale, S. (1996). Interviews. Thousand Oaks, CA: Sage Publications.

March, J. (1994). A primer on decision-making. New York: Simon \& Schuster.

Merriam, S. (1998). Qualitative research and case study applications in education. San Francisco: Jossey-Bass.

Meyer, J.W., \& Scott, W.R. (1983). Organizational environments: Ritual and rationality. Beverly Hills, CA: Sage Publications. 
Mintzberg, H., Ahlstrand, B., \& Lampel, J. (1998). Strategy Safari. London: Prentice Hall.

Morgan, H.M., \& Wofford, J.W. (1977). Declining enrollment, rising school costs: One school's response: Identification of appropriate models of cost reduction (capital and man-power) and specific application using a local decisionmaking process. Lincoln-Sudbury, MA: Lincoln-Sudbury Regional School District.

Nowakowski, J.A. (1980). Hidden opportunites in declining enrollments. American School and University: 4, 40-44.

Nuttall, R.L. (1976). Positions on declining enrollment issues and school values commitment. Paper presented at the annual meeting of the American Educational Research Association: 122(433), 1-22.

Pfeffer, J. (1992). Managing with power: Politics and influence in organizations. Boston: Harvard Business School Press.

Pfeffer, J. \& Selancik, G.R. (2003). The external control of organizations: A resource dependence perspective ( $2^{\text {nd }}$ ed.). Stanford, CA: Stanford Business Books.

Quinn, R. (1996). Deep Change. San Francisco: Jossey-Bass.

Rainey, H. (2003). Understanding and Managing Public Organizations ( $3^{\text {rd }}$ ed.). San Francisco: Jossey-Bass.

Sargent and Handy, (1974). Fewer Pupils/Surplus Space. A Report. New York, New York: Educational Facilities Laboratories, Inc.

Schein, E.H. (1992). Organizational culture and leadership (2 ${ }^{\text {nd }}$ ed.). San Francisco: Jossey-Bass.

Scott, R. (1995). Institutions and Organizations. Thousand Oaks, CA: Sage Publications. 
Shook, C. (1998). Turning around turnaround research: The value of process in advancing knowledge. In D. Ketchen (ed.), Turnaround research: Past accomplishments and future challenges, pp. 261-280. London: JAI.

Stake, R. (1995). The art of case study research. Thousand Oaks, CA: Sage Publications. Taxpayers' Federation of Illinois. (1994). 1994 Practical guide to Illinois real estate taxation. Springfield, IL: J. Gordon, \& C.D. Romans.

Thompson, J.D. (2006). Organizations in action: Social science bases of administrative theory $\left(4^{\text {th }}\right.$ ed.). New Brunswick, NJ: Transaction Publishers.

Winn, J. (1993). Performance measures for corporate decline and turnaround. Journal of General Management, 19, 48-63.

Yeager, R. (1979). Rationality and Retrenchment: The use of computer simulation to aid decision making in school closings. Education and Urban Society. (11, 3), 296312.

Yin, R. (1994). Discovering the future of the case study method in evaluation research. Evaluation Practice. (15, 3). 283-290.

Zerchykov, R. (1982). A review of the literature and an annotated bibliography on managing decline in school systems. Boston: The Institute for Responsive Education. 


\section{DEDICATION}

As I consider all the people for whose help I am grateful, I have come to the fact that I will most certainly leave out some names who should appear here, and to them, I apologize.

To my dissertation committee, thank you for your effort in guiding me through the dissertation process. Your sage advice has led me to this point, and for that I am grateful.

To my parents, Jim and Wanda, I'm sure I was the last of your three children you thought would actually have a dissertation where you could be thanked. I guess this proves that lazy children can change!

To my three wonderful children: Isaac, Eli and Clara, I hope some day you read this and understand how proud I am of each one of you. You have had to share your father with so many other people for so long, yet you rarely complain. I love you all very much.

To my wife, Julie, where to begin? I would have had no chance of ever completing this degree if it weren't for your constant support and love. I will be forever grateful to you. This degree is for both of us. I love you and thank you from the bottom of my heart.

And finally, I have to give all glory to God, for none of this would have been possible without the gifts you have given me.

Respectfully Submitted

John A. Asplund 
